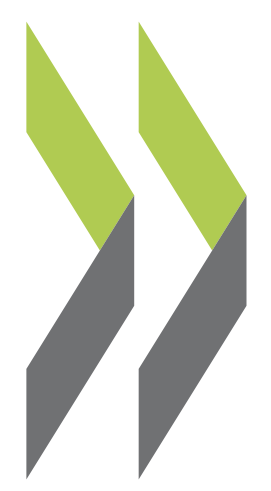

OECD Science, Technology and Industry Working Papers 2019/04

Exploring changes in world production and trade: Insights from the 2018 update of OECD's ICIO/ TIVA database
Joaquim Guilhoto, Geoffrey Hewings, Nick Johnstone, Colin Webb, Norihiko Yamano 
OECD Science, Technology and Industry Working Papers

The release of this working paper has been authorised by Andrew Wyckoff, OECD Director for Science, Technology and Innovation, and by Ken Ash, OECD Director for Trade and Agriculture.

OECD Working Papers should not be reported as representing the official views of the OECD or of its member countries. The opinions expressed and arguments employed arethose of the authors. Working Papers describe preliminary results or research in progress by the author(s) and are published to stimulate discussion on a broad range of issues on which the OECD works. Comments on Working Papers are welcomed, and may be sent to Directorate for Science, Technology and Innovation, OECD, 2 rue André-Pascal, 75775 Paris Cedex 16, France.

This document, as well as any data and any map included herein, are without prejudice to the status of or sovereignty over any territory, to the delimitation of international frontiers and boundaries and to the name of any territory, city or area.

The statistical data for Israel are supplied by and under the responsibility of the relevant Israeli authorities. The use of such data by the OECD is without prejudice to the status of the Golan Heights, East Jerusalem and Israeli settlements in the West Bank under the terms of international law.

Note to Delegations:

This document is also available on O.N.E under the reference code:

DSTI/CIIE(2019)4/FINAL

This document, as well as any data and any map included herein, are without prejudice to the status of or sovereignty over any territory, to the delimitation of international frontiers and boundaries and to the name of any territory, city or area.

(C) OECD (2019) You can copy, download or print OECD content for your own use, and you can include excerpts from OECD publications, databases and multimedia products in your own documents, presentations, blogs, websites and teaching materials, provided that suitable acknowledgment of OECD as source and copyright owner is given. All requests for commercial use and translation rights should be submitted to rights@oecd.org. 


\title{
EXPLORING CHANGES IN WORLD PRODUCTION AND TRADE
}

\author{
INSIGHTS FROM THE 2018 UPDATE OF \\ OECD'S ICIO/TIVA DATABASE
}

\author{
Joaquim J.M. GUILHOTO, Geoffrey J.D. HEWINGS (University of Illinois), \\ Nick JOHNSTONE (IEA), Colin WEBB and Norihiko YAMANO
}

\begin{abstract}
This paper explores changes in the structure of trade in value added drawing on the newlyreleased 2018 update to the ICIO/TiVA database that covers 64 countries (plus an aggregate "Rest of World), and 36 industries. Exploring the data over the period from 2005 to 2015 , selected aspects of world-wide changes in international production systems were uncovered with subsequent attention to four key sectors that are heavily integrated in the world trading system: Textiles \& Apparel; Chemicals; ICT and Electronics; and, Motor Vehicles. And finally providing some insights into the employment and environmental impacts of trade.

There is considerable heterogeneity in recent developments, with some countries experiencing declines in their integration in global value chains (such as France, Germany and Korea), while others experienced growth (such as Australia and Norway) and still other countries (such as the Russia Federation) have experienced a more cyclical pattern of growth and decline followed by modest growth. At the regional level, overall the sourcing of trade changed very little (intra- versus inter-regional), with the notable exception of East and Southeast Asia where it is striking the role played by the Chinese economy in the regional and global trade. In Europe and North America, the changes in intra-regional trade were very small.
\end{abstract}

Attention is also directed to the increasing role of services in manufacturing exports; for all countries, this share has increased over the period from 2005 to 2015 with most countries recording values between $25 \%$ and $40 \%$. In addition, non-resident expenditures (primarily from tourism) recorded some important changes. For over half the countries, the contributions account for less than $5 \%$ of total exports but for some countries, such as Greece, the share exceeds $20 \%$.

The paper also explores aspects of changes in labor demand and the contributions to greenhouse gas emissions, areas in which the application of the ICIO/TiVA database is particularly enlightening. Many countries that have already been actively participating in GVCs are increasingly looking to "upgrade" their GVC activities to higher value added stages of production, and to accomplish this skilled labor plays a key role. The distinction between accounting for pollution at the source of production or the source of final consumption has occupied a prominent role in the academic literature, with concerns that efforts to mitigate GHGs in one set of countries resulting in counterbalancing emissions from other countries through imports.

Keywords: Inter-Country Input-Output; Trade in Value Added, Trade in Employment, $\mathrm{CO}_{2}$ Emissions Embodied in Trade, International Trade

JEL Code: F14, F15, F16, F18, R15, C67 


\section{Table of contents}

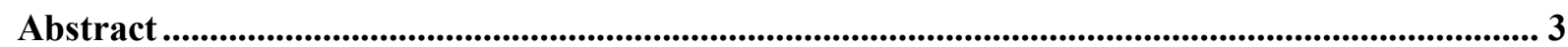

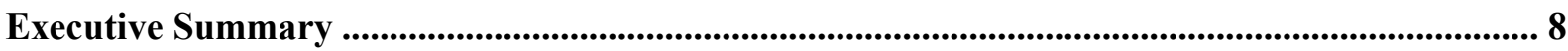

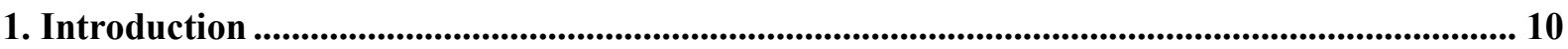

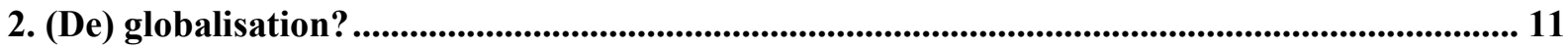

3. Globalisation or regionalisation? ...................................................................................................... 16

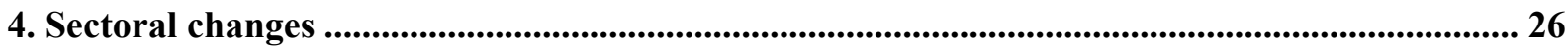

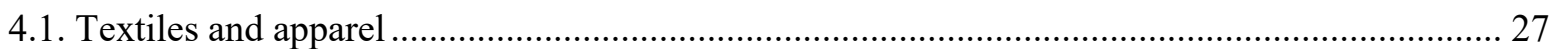

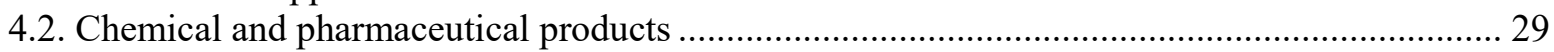

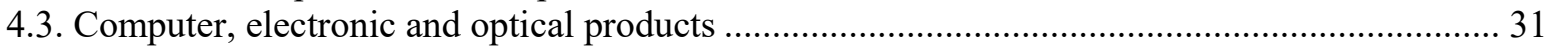

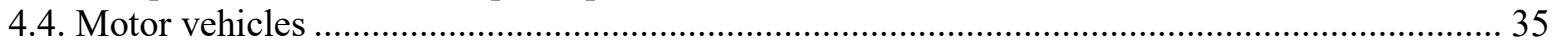

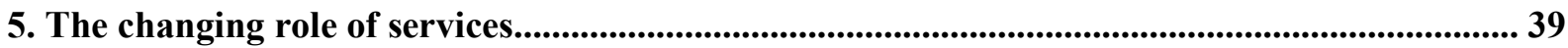

6. Extensions: labour market and climate change impacts ................................................................... 42

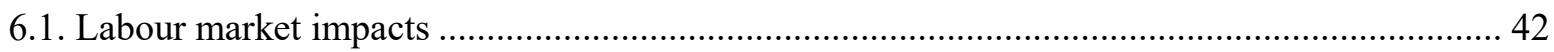

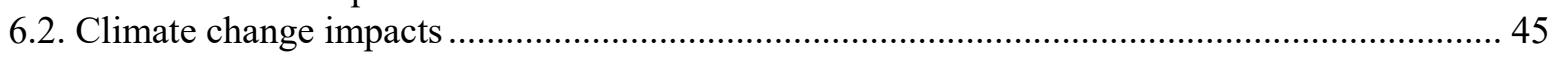

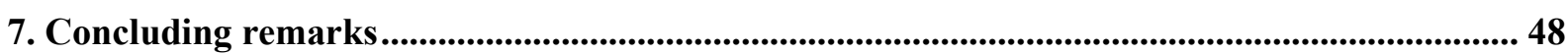

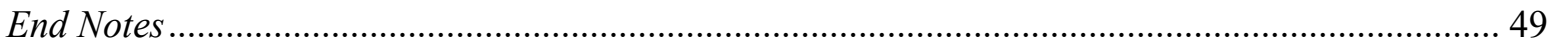

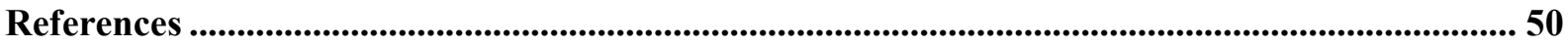

Annex A. TiVA 2018 geographical coverage........................................................................................... 53

Annex B. Expanded data used in charts..................................................................................................... 55

Tables

Table B.1. Foreign value added shares of total exports, $2010=1.00$, by region (Figure 2.1) .............. 55

Table B.2. Foreign value added shares of total exports for selected countries, $2010=1.00$

(Figure 2.2).

Table B.3. Foreign value added share of total gross exports, as a percentage of total gross exports

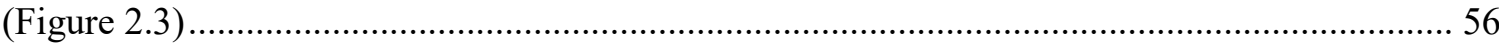

Table B.4. Foreign value added share of manufactured exports, as a percentage of total

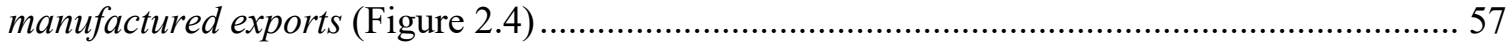

Table B.5. Domestic value added embodied in foreign exports, as a percentage of total gross

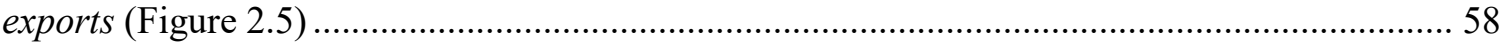

Table B.6. Regional demand for manufactured goods, 2005 and 2015, by economy or region of value added origin, percentage shares of total (Figure 3.1) ......................................................... 59

Table B.7. Regional demand for manufactured goods and business services, 2005 and 2015, by economy or region of value added origin, percentage shares of total (Figure 3.2) ...................... 60

Table B.8. Origin of foreign value added in domestic final demand for manufactured goods and business services. Intra-regional versus extra-regional (ROW) origin, selected countries, 2005 to 2015, USD Millions and percentage shares (Figure 3.3)..... 
Table B.9. Domestic value added in foreign final demand for manufactured goods and business services. Intra-regional versus extra-regional (ROW) demand, selected countries, 2005 to 2015, USD Millions and percentage shares (Figure 3.4)....

Table B.10. Foreign value added in domestic final demand for manufactured goods, intra-regional versus extra-regional (ROW) origin, selected countries, 2005 to 2015, USD Millions and percentage shares (Figure 3.5).....

Table B.11. Domestic value added in foreign final demand for manufactured goods, intra-regional versus extra-regional (ROW) demand, selected countries, 2005 to 2015, USD Millions and percentage shares (Figure 3.6).....

Table B.12. Final destination of intermediate exports by importing region, intra-regional versus extra-regional, selected countries, 2005 to 2015, USD Million (Figure 3.7)...

Table B.13. Foreign value added embodied in domestic final demand by sector, global average, 2015. As a percentage of total domestic demand (Figure 4.1)

Table B.14. Foreign value added embodied in domestic final demand, by sector, OECD average, 2015. As a percentage of total domestic demand (Figure 4.2)

Table B.15. Global demand for Textiles and apparel, by country or region of final demand and origin of value added, percentage shares of total, 2005 and 2015 (Figure 4.3)

Table B.16. Regional demand for Textiles and apparel by economy or region of value added origin, percentage shares of total, 2005 and 2015 (Figure 4.4)

Table B.17. Foreign value added embodied in domestic demand for Textiles and apparel by source region, as a percentage of total domestic demand (Figure 4.5)

Table B.18. Global demand for Chemical and pharmaceutical products, by country or region of final demand and origin of value added, percentage shares of total, 2005 and 2015 (Figure 4.6)

Table B.19. Regional demand for Chemical and pharmaceutical products, by economy or region of value added origin, percentage shares of total, 2005 and 2015 (Figure 4.7)...

Table B.20. Foreign value added embodied in domestic demand for Chemical and pharmaceutical products, by source region, 2015, as a percentage of total domestic demand (Figure 4.8) .......... 73

Table B.21. Global demand for Computer, electronic and optical products, by country or region of final demand and origin of value added, percentage shares of total, 2005 and 2015 (Figure 4.9)....

Table B.22. Regional demand for Computer, electronic and optical products, by economy or region of value added origin, percentage shares of total, 2005 and 2015 (Figure 4.10)....

Table B.23. Foreign value added embodied in domestic demand for Computer, electronic and optical products, by source region, 2015, as a percentage of total domestic demand (Figure 4.11).

Table B.24. Global demand for Motor vehicles, by country or region of final demand and origin of value added, percentage shares of total, 2005 and 2015 (Figure 4.12)

Table B.25. Regional demand for Motor vehicles by economy or region of value added origin, percentage shares of total, 2005 and 2015 (Figure 4.13)

Table B.26. Foreign value added embodied in domestic demand for Motor vehicles, by source region, as a percentage of total domestic demand (Figure 4.14) ............................................... 79

Table B.27. Services value added embodied in manufactured exports, by domestic and foreign origin, 2015, as a percentage of total manufacturing exports (Figure 5.1)................................. 81

Table B.28. Non-residents' expenditure by origin of value added, 2015 as a percentage of total gross exports (Figure 5.2).

Table B.29. Jobs in the business sector sustained by foreign demand, by region of demand, 2015, as a percentage of total business sector employment (Figure 6.1). 
Table B.30. Labour compensation of employees in business sector embodied in foreign demand, by region of demand, 2015, as a percentage of total business sector labour compensation of employees (Figure 6.2)

Table B.31. High-skilled employment in manufacturing meeting domestic and foreign demand, 2015, as a percentage of total manufacturing employment (Figure 6.3)..................................... 88

Table B.32. $\mathrm{CO}_{2}$ emissions from fuel combustion (OECD and non-OECD countries), consumptionbased and production-based (Gt CO2) (Figure 6.4) ....

Table B.33. Per capita $\mathrm{CO}_{2}$ emissions from fuel combustion, consumption-based and productionbased (tonnes $\mathrm{CO} 2$ ) (Figure 6.5)

Table B.34. Share of $\mathrm{CO} 2$ emitted abroad in total $\mathrm{CO} 2$ embodied in domestic final demand (Figure 6.6).....

Table B.35. Regional demand for information industries products, 2005 and 2015, by country or region of value added origin, percentage shares of total (Box 4.1).

Table B.36. US imports of electronics, machinery and transport equipment from Mexico, by country or region origin of value added, 2005 to 2015, USD billions (Box 4.2).

Table B.37. US imports of electronics, machinery and transport equipment from Mexico, by country or region and industry origin of value added, 2015, USD millions (Box 4.2)...

\section{Figures}

Figure 2.1. Foreign value added shares of total exports, $2010=1.00$, by region.................................. 12

Figure 2.2. Foreign value added shares of total exports, $2010=1.00$, selected countries ................... 12

Figure 2.3. Foreign value added share of total gross exports, as a percentage of total gross exports .. 13

Figure 2.4. Foreign value added share of manufactured exports, as a percentage of total manufactured exports

Figure 2.5. Domestic value added embodied in foreign exports, as a percentage of total gross exports ......

Figure 3.1. Regional demand for manufactured goods, 2005 and 2015, by economy or region of value added origin, percentage shares of total ....

Figure 3.2. Regional demand for manufactured goods and business services, 2005 and 2015, by economy or region of value added origin, percentage shares of total .....

Figure 3.3. Origin of foreign value added in domestic final demand for manufactured goods and business services, intra-regional versus extra-regional (ROW) origin, selected countries, 2005 to 2015, USD Millions and percentage shares....

Figure 3.4. Domestic value added in foreign final demand for manufactured goods and business services, intra-regional versus extra-regional (ROW) demand, selected countries, 2005 to 2015, USD Millions and percentage shares.

Figure 3.5. Foreign value added in domestic final demand for manufactured goods, intra-regional versus extra-regional (ROW) origin, selected countries, 2005 to 2015, USD Millions and percentage shares.....

Figure 3.6. Domestic value added in foreign final demand for manufactured goods, intra-regional versus extra-regional (ROW) demand, selected countries, 2005 to 2015, USD Millions and percentage shares.

Figure 3.7. Final destination of intermediate exports by importing region, intra-regional versus extra-regional, selected countries, 2005 to 2015, as a percentage share of total intermediate export......

Figure 4.1. Foreign value added embodied in domestic final demand by sector, global average, 2015 , as a percentage of total domestic demand.

Figure 4.2 Foreign value added embodied in domestic final demand, by sector, OECD average, 2015 , as a percentage of total domestic demand. 
Figure 4.3. Global demand for Textiles and apparel, by country or region of final demand and origin of value added, percentage shares of total, 2005 and 2015.

Figure 4.4. . Regional demand for Textiles and apparel by economy or region of value added origin, percentage shares of total, 2005 and 2015

Figure 4.5. Foreign value added embodied in domestic demand for Textiles and apparel by source region, as a percentage of total domestic demand .

Figure 4.6. Global demand for Chemical and pharmaceutical products, by country or region of final demand and origin of value added, percentage shares of total, 2005 and 2015 .....

Figure 4.7. Regional demand for Chemical and pharmaceutical products, by economy or region of value added origin, percentage shares of total, 2005 and 2015 .

Figure 4.8. Foreign value added embodied in domestic demand for Chemical and pharmaceutical products, by source region, 2015, as a percentage of total domestic demand ...

Figure 4.9. Global demand for Computer, electronic and optical products, by country or region of final demand and origin of value added, percentage shares of total, 2005 and 2015 .................. 32

Figure 4.10. Regional demand for Computer, electronic and optical products, by economy or region of value added origin, percentage shares of total, 2005 and 2015 ........................................... 32

Figure 4.11. Foreign value added embodied in domestic demand for Computer, electronic and optical products, by source region, 2015, as a percentage of total domestic demand ................... 33

Figure 4.12. Global demand for Motor vehicles, by country or region of final demand and origin of value added, percentage shares of total, 2005 and 2015

Figure 4.13. Regional demand for Motor vehicles by economy or region of value added

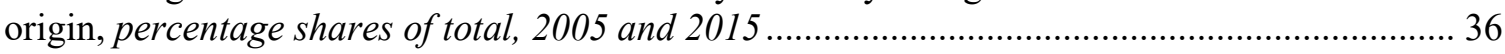

Figure 4.14. Foreign value added embodied in domestic demand for Motor vehicles, by source

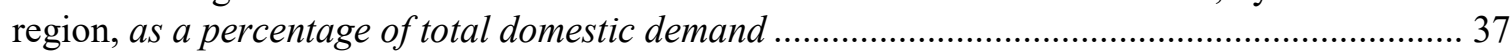

Figure 5.1. Services value added embodied in manufactured exports, by domestic and foreign origin, 2015, as a percentage of total manufacturing exports.

Figure 5.2. Non-resident households' expenditure by origin of value added, 2015 as a percentage

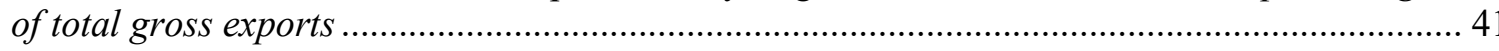

Figure 6.1. Jobs in the business sector sustained by foreign demand, by region of demand, 2015, as a percentage of total business sector employment ……............................................................... 43

Figure 6.2. Labour compensation of employees in business sector embodied in foreign demand, by region of demand, 2015, as a percentage of total business sector labour compensation of

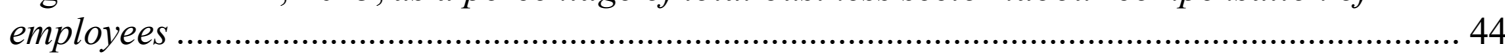

Figure 6.3. High-skilled employment in manufacturing meeting domestic and foreign demand, 2015 , as a percentage of total manufacturing employment.

Figure 6.4. $\mathrm{CO}_{2}$ emissions from fuel combustion (OECD and non-OECD countries), consumptionbased and production-based $\left(\mathrm{Gt} \mathrm{CO}_{2}\right)$

Figure 6.5. Per capita $\mathrm{CO}_{2}$ emissions from fuel combustion, consumption-based and productionbased (tonnes $\mathrm{CO}_{2}$ )

Figure 6.6. Share of $\mathrm{CO}_{2}$ emitted abroad in total $\mathrm{CO}_{2}$ embodied in domestic final demand ......... 47

\section{Boxes}

Box 4.1. The Case of "Information industries"

Box 4.2. Origin of Value added in US imports from Mexico 


\section{Executive Summary}

This report explores changes in the structure of world production and trade drawing on the recently released 2018 update of OECD's Inter-Country Input-Output (ICIO) database and related collection of Trade in Value Added (TiVA) indicators ${ }^{1}$. Selected aspects of worldwide changes in international production systems are analysed over the period 2005 to 2015 with particular attention given to four key sectors heavily integrated in global production systems. Finally, some insights into the impacts of global value chains (GVCs) on employment and the environment are provided.

There is considerable heterogeneity in recent developments, with some countries (such as France, Germany and Korea) experiencing declines in their integration into GVCs, others experiencing growth (such as Australia and Norway) while others (for example, the Russian Federation) have experienced a more cyclical pattern of growth and decline followed by modest growth. For the OECD as a whole, the growth in the level of integration into GVCs from 2005 was interrupted by the Great Recession (2008-09); from 2009 to 2012 , there was a period of pronounced growth but in the last three years, the curve has turned downwards again. While East and Southeast Asia had a similar pattern through to 2012, growth has continued since, with little evidence of a downturn. Other major regions, such as the European Union and North America, experienced similar trends to OECD as a whole. Overall the sourcing of trade, intra- versus inter-regional, changed very little with the notable exception of East and Southeast Asia where the role played by the Chinese economy in regional and global trade is striking. The increased dependence and integration among the East and Southeast Asian economies is a result of the organisation within the region to produce goods and services to fulfil the growing extra-regional demand and, domestic demand in the People's Republic of China (hereafter "China"). In the European Union and North America, changes in intra-regional trade were relatively small.

The characteristics of international trade vary across sectors. Four manufacturing sectors heavily involved in global value chains were chosen for more detailed analysis, namely: Textiles and apparel; Chemicals and pharmaceutical products; Computer, electronic and optical products; and, Motor vehicles ${ }^{2}$.

For the Textiles and apparel sector, the European Union's shares of global final demand and value added witnessed some of the largest declines - almost 10 and 13 percentage points respectively; North America also recorded declines of 7 and 6 percentage points with respect to final demand and value added respectively. Much of this change in global final demand was counterbalanced by China (gains of 7 and 15 percentage points) and the rest of the World (7 and 3 percentage points). Within East and Southeast Asia, China's share of final demand increased from $49 \%$ to $70 \%$ with declines in Japan and Korea. Intra- versus inter-regional sourcing did change, with the European Union, for example, experiencing a decrease in the former from $70 \%$ to $52 \%$.

For Chemical and pharmaceuticals, changes were much smaller. For example, North America's share of global final demand declined from $36 \%$ to $33 \%$ while the share of global value added declined from $32 \%$ to $29 \%$. The European Union's decline was more pronounced - a drop in the share of final demand from $32 \%$ to $20 \%$ with a corresponding decline in value added from $33 \%$ to $24 \%$. Most of the increases in final demand were recorded in China (increasing its share from 6\% to 16\%) and the rest of the World (from 
$11 \%$ to $15 \%$ ). The corresponding value added share of China increased from $6 \%$ to $16 \%$ while the rest of the World's share increased from $16 \%$ to $17 \%$.

For Computer, electronic and optical products, the changes were most often in a different direction. The value added sourced from within the United States to meet US final demand for Computer, electronic and optical products increased from $81 \%$ to $85 \%$. In China the share increased from $59 \%$ to $70 \%$ while for the European Union, the share declined from $82 \%$ to $79 \%$. For the US, the composition of external sources of value added changed more markedly with Japan's share declining (from 12\% to 5\%), while the share from China increased from $18 \%$ to $28 \%$.

The Motor vehicles sector was one of seven sectors that recorded declines in the foreign value added content of domestic final demand at the global level. The share in global final demand of North America increased from 32\% to 35\% while the European Union's share declined (33\% to $18 \%$ ) as did Japan's (from $8 \%$ to $3 \%$ ) much of which was offset by China's increasing share (6\% to $21 \%$ ). In global value added terms, North America increased its share from $24 \%$ to $26 \%$ while Japan's share declined by almost $50 \%$ (14\% to $7 \%$ ) with China's share more than tripling, from 6 to $21 \%$.

Attention is also directed towards the increasing role of services in international trade. For most countries, the service content of manufactured exports increased between 2005 and 2015. For most OECD countries, services value added accounts for between $25 \%$ and $40 \%$ of the value of manufactured exports.

In addition to cross-border transactions, goods and services (such as transport and accommodation) can also be exported via non-resident expenditure on the domestic territory (e.g. from tourism activities or presence of foreign students). While for many countries such spending accounts for less than 5\% of total exports, for some, such as Greece, Costa Rica, New Zealand and Turkey the share exceeds 20\%.

The last two sections explore other consequences of GVCs, notably the impacts on domestic labour markets and the environment - areas in which the application of ICIO tables can be particularly enlightening ${ }^{3}$. Many countries that are already actively participating in GVCs are increasingly looking to "upgrade" their GVC activities to higher value added stages of production, and to accomplish this, skilled labour plays a key role. It is interesting to note that for some relatively large European economies (e.g. Germany, France, Italy, Sweden, and the Netherlands) foreign final demand is more important than domestic final demand in supporting high-skilled employment. Much of this is attributable to intra-regional fragmentation of production.

The distinction between accounting for pollution at the source of production or at the source of final consumption has occupied a prominent role in the academic literature, with concerns that efforts to mitigate greenhouse gases (GHGs) in one set of countries can result in counterbalancing emissions from other countries through imports. Our results reveal that for $\mathrm{CO}_{2}$ emissions from fuel combustion, net imports by OECD countries from non-OECD countries fell from 2.1 to 1.6 Gigatonnes (Gt) between 2005 and 2015. 


\section{Introduction}

Over the last 50 years, despite various economic crises, including the recent slowdown in the international trade following the Great Financial Crisis, it is impressive how the structure of global trade has changed, with predominantly bilateral trade relationships morphing into more global networks of international production. This is partly a consequence of multilateral agreements and the associated reduction in tariffs. At the same time, international transportation and transfer costs have moved steadily downwards in real terms as larger vessels and more efficient movement (containerization) have yielded significant savings to shippers.

In recent decades, production has been split into optimal subsets to exploit scale economies at each stage; increasingly, this production is being organised across many different countries, where location-specific competitive advantages can be exploited. Taking advantage of these developments, multinational firms have embraced new global organisational structures characterised as the international fragmentation of production. ${ }^{4}$ Lower trade and transportation costs make this new spatial organization of production possible and one outcome has been an increase in the number of "border crossings" associated with the final assembly of a good.

As a result, production systems can now be incredibly complex and fragmented. However, a drawback of fragmentation comes from increased vulnerability to disruptions in production, whether generated by unexpected natural events (hurricanes, floods, earthquakes) or human-induced events such as labour disputes (e.g. a strike in a component manufacturing facility) and trade wars with the imposition of higher tariffs and retaliatory actions. Constraints on access to inputs from a source at one specific point in the supply chain can bring a global assembly line to a halt, particularly since pressures for efficiency have all but eliminated secondary sources for the supply of key components.

Changing patterns of global value chains (GVCs) effect not only trade, but also associated factors of production such as labour markets and capital flows. Many ancillary impacts are also apparent such as income distribution, poverty and pollution emissions. In this report, the impacts of GVCs on labour markets are examined by focusing on employment sustained by production to meet foreign demand and, the related skill composition. In addition, increased internationalization of production co-exists with increased interdependence of other systems, with climate change (as a global public "bad") being an obvious example. This report also considers the manner in which the fragmentation of production can serve as a mechanism through which $\mathrm{CO}_{2}$ emissions are embodied in trade through indirect linkages.

The next section examines recent changes in globalisation. The following section reviews evidence on how these changes are manifested in intra-regional or extra-regional trade. Section 4 focuses on four manufacturing sectors that are major participants in global trade. The role of services in international trade is then explored in more detail in Section 5. The penultimate section offers some insights into changes in global demand for labour market skills and, the impact of trade on $\mathrm{CO}_{2}$ emissions, exploring distinctions between production-based and consumption-based assessments. The concluding section offers some potential avenues for further analysis. The geographical coverage of TiVA 2018 and the data used in the charts are provided in the Annexes. 


\section{2. (De) globalisation?}

In recent years, and especially since the recovery from the Great Financial Crisis, there has been considerable discussion about the degree to which trade may have been affected by more protectionist movements within major world economies, or even planned policies to reduce external dependence. In the last decade, several organizations have assembled multi-country trade databases based on harmonised input-output data. As a result, there has been a dramatic increase in the number of academic papers that have drawn upon one or more of these databases to explore changes in the structure of the global trading economy. ${ }^{5}$ The OECD's recently released Inter-Country Input-Output (ICIO) tables and related collection of Trade in Value Added (TiVA) indicators ${ }^{6}$ (hereinafter referred to as the OECD ICIO/TiVA database) serve as the principle sources for the results presented in this paper.

Relative to previous versions of the OECD ICIO/TiVA database, there have been a number of methodological developments with important implications for analysis, among which: a) use of statistics defined according to the 2008 System of National Accounts (SNA 2008) while previously, SNA 1993 statistics were used; b) under SNA 2008, expenditures on Research and Development (R\&D) and Weapons systems (warships, submarines, military aircraft, tanks, etc.) are recorded as gross fixed capital formation (GFCF), i.e. investments, rather than as intermediate inputs - the practice under SNA 1993; c) the "change in ownership principle", under SNA 2008, and the treatment of transactions due to processing a ("manufacturing services on physical inputs owned by others"); d) use of an industry list based on the $4^{\text {th }}$ revision of the International Standard Industrial Classification (ISIC Rev.4) while in the previous versions ISIC Rev.3 was used; and e) the possibility to access new and revised statistics. ${ }^{7}$

Many measures have been developed in recent years to provide insights into global production and trade, often based on the origins of value added in gross exports or, in final demand. A popular indicator is foreign value added share of total exports (often considered as a measure of backward linkages in GVCs) presented in Figure 2.1 to Figure 2.4. For major blocs of countries, over the most recent years, the general trend in foreign contents of exports has been downward. The notable exception is South and Central America, where there has been a marked increase over the period, albeit from relatively low levels. Figure 2.2 shows that the patterns of change can be very different at the individual country level with very distinctive trends even within the same trading bloc (see the different trajectories of the United States, Canada and Mexico). For some countries the trend has changed (e.g. Japan) with increases through 2014 then had a sharp downward trend. In the case of the Russian Federation, the experience is the opposite, although less pronounced in magnitude. 
Figure 2.1. Foreign value added shares of total exports, $2010=1.00$, by region

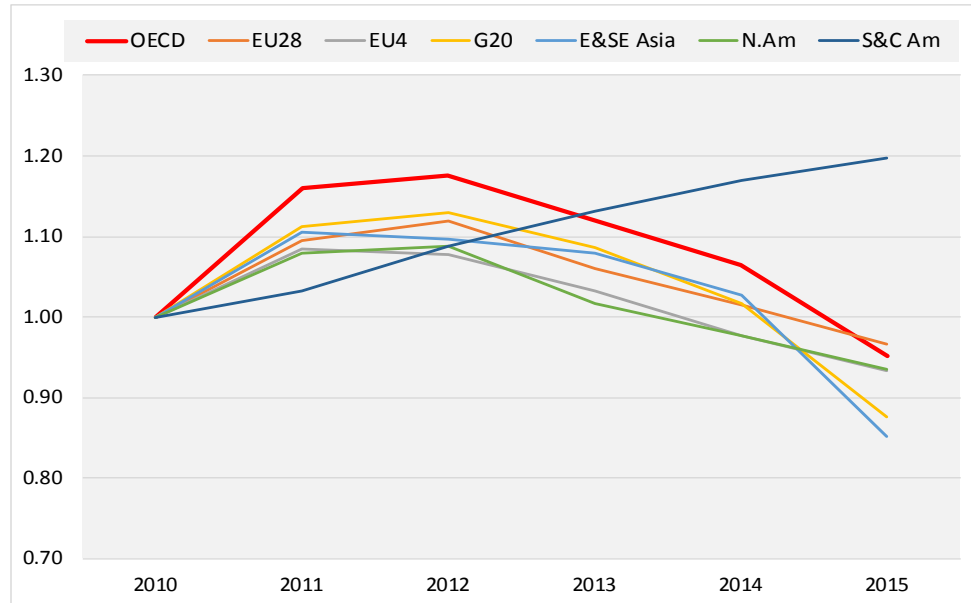

Source: Estimation based on OECD’s Inter-Country Input-Output (ICIO) Database, 2018

Figure 2.2. Foreign value added shares of total exports, $2010=\mathbf{1 . 0 0}$, selected countries

Selected countries experiencing declines
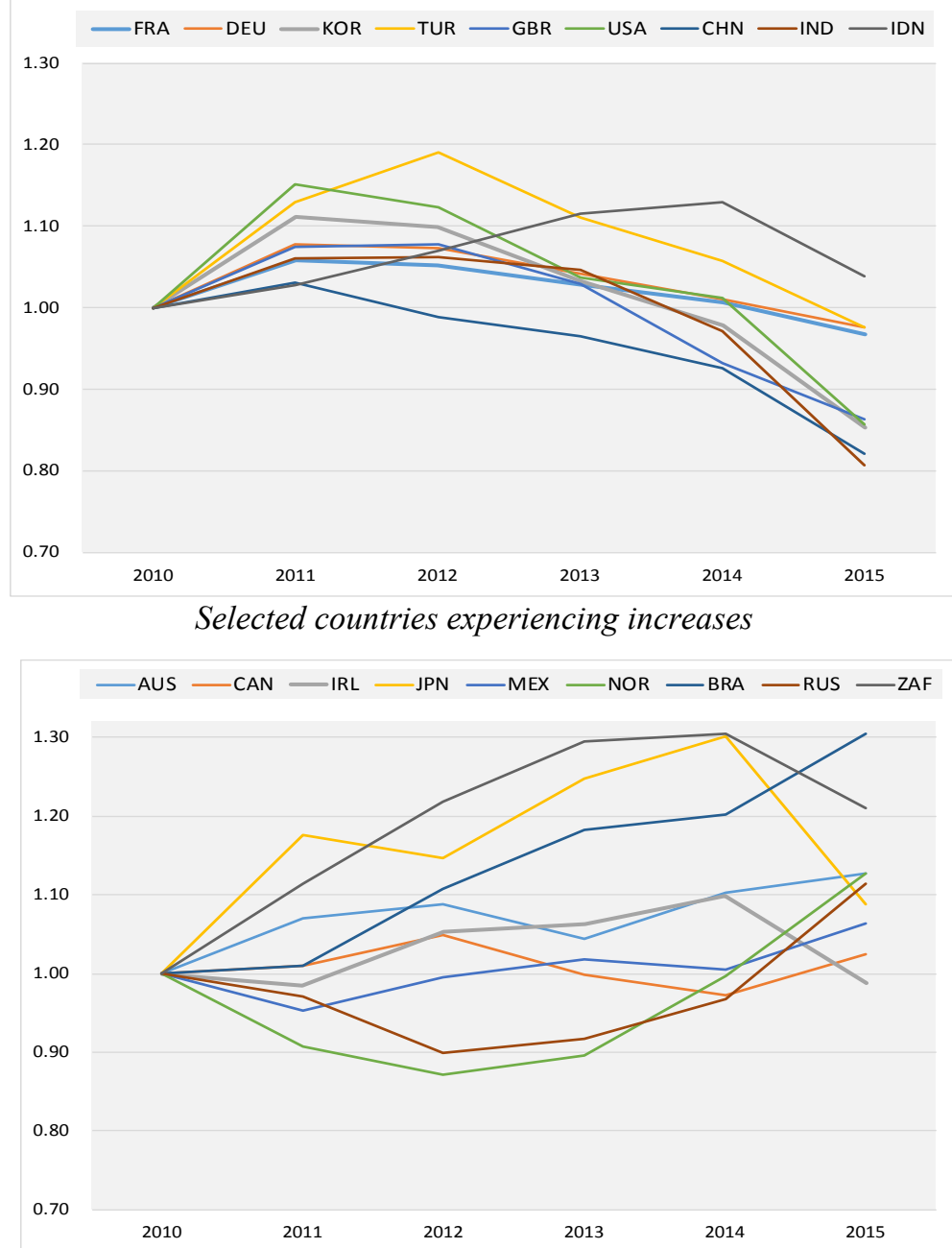

Source: OECD, Trade in Value Added (TiVA) database, http://oe.cd/tiva, 2018. 
Figure 2.3 and Figure 2.4 help cast light on more recent trends. From 2005 to 2015, eight countries reduced their dependence on foreign value added in their supply chains (backward linkage in GVCs), with China exhibiting one of the steepest declines (by ten percentage points). The countries that experienced large increases in the foreign content of exports tended to be small in terms of the volume of trade; most European countries increased their use of foreign inputs as did Canada while Mexico and USA, slightly reduced theirs. Most of these changes were associated with shifts in demand for manufactured goods.

Figure 2.3. Foreign value added share of total gross exports, as a percentage of total gross exports

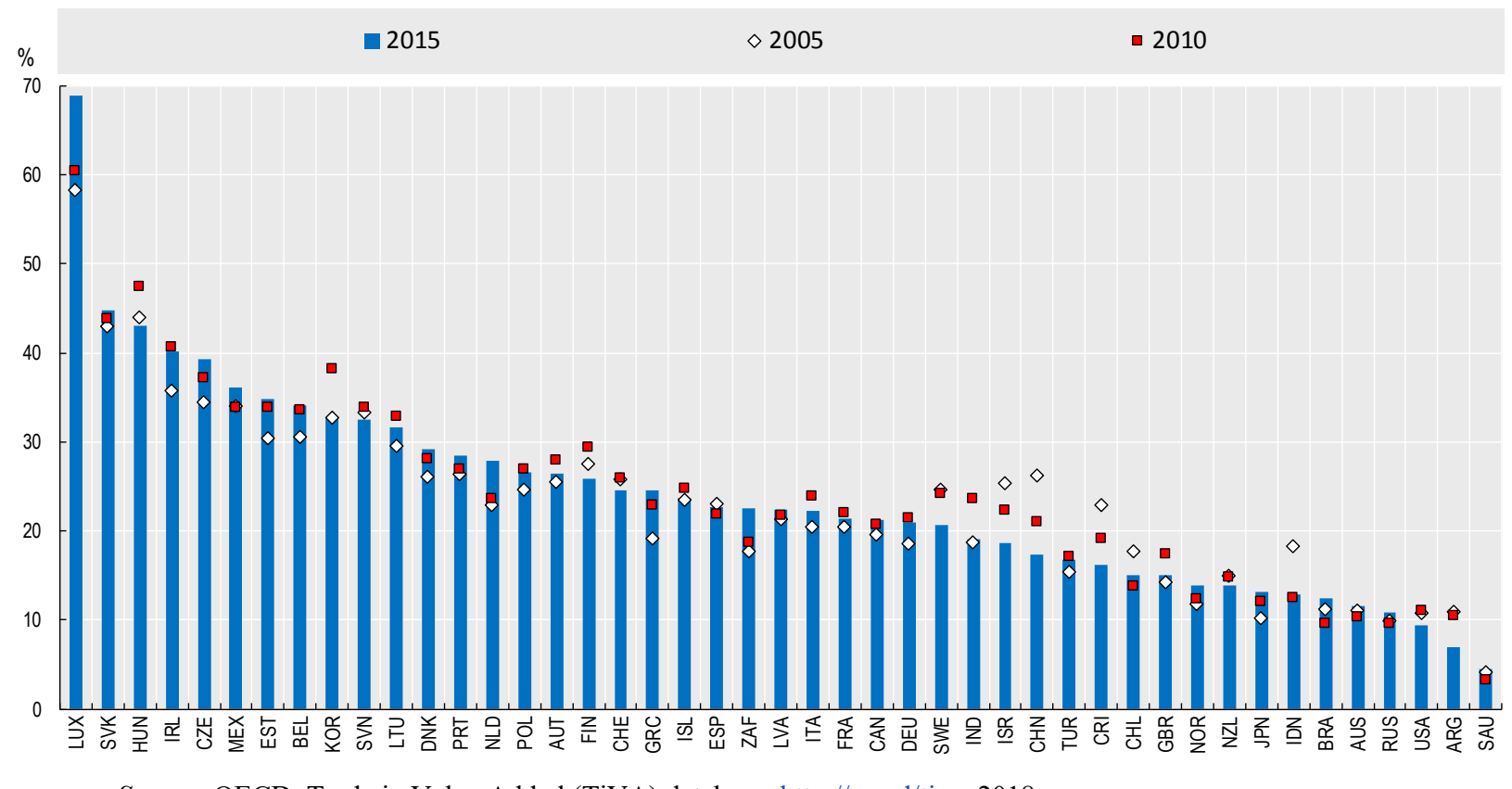

Source: OECD, Trade in Value Added (TiVA) database, http://oe.cd/tiva, 2018. 
Figure 2.4. Foreign value added share of manufactured exports, as a percentage of total manufactured exports

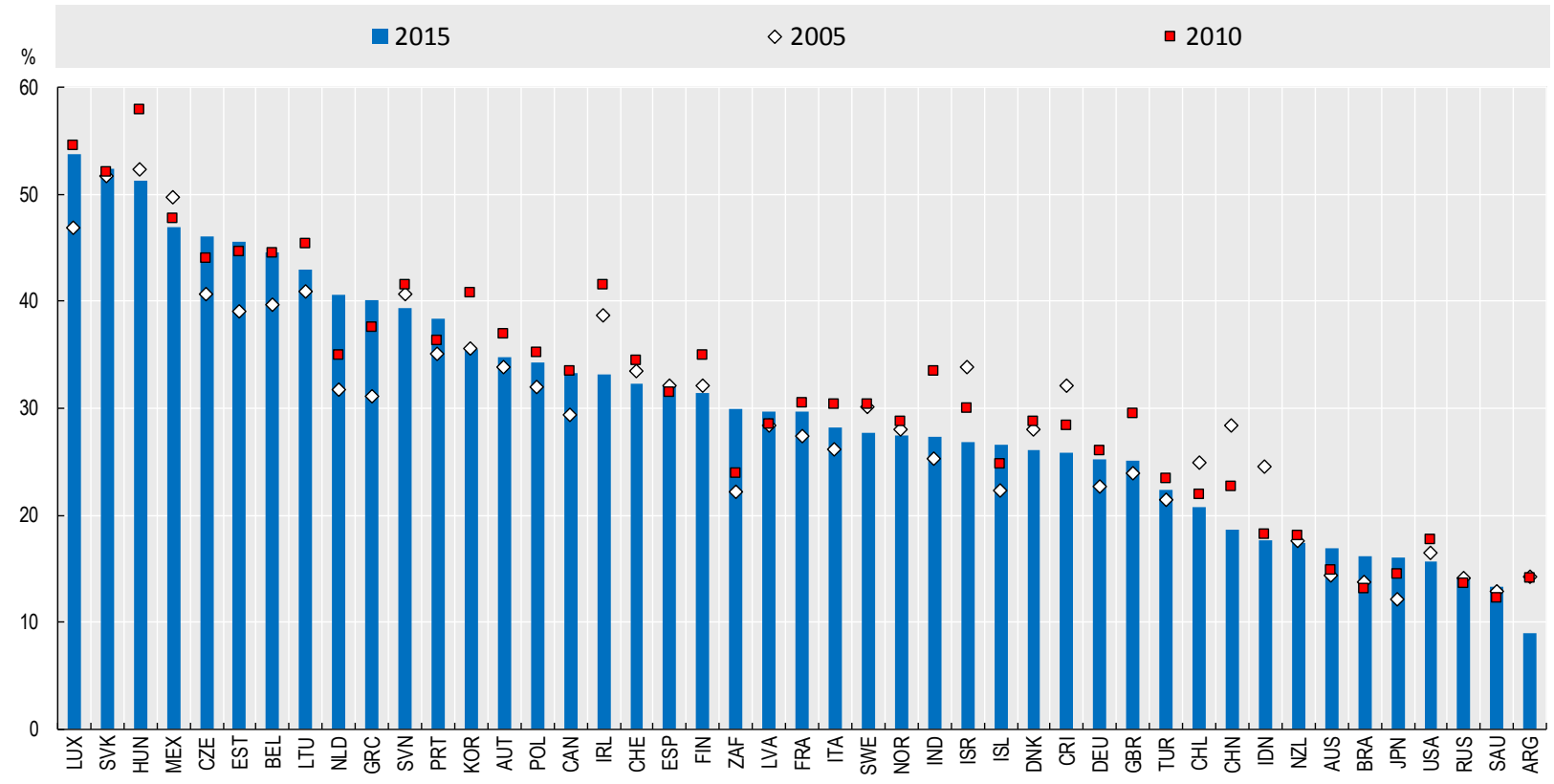

Source: OECD, Trade in Value Added (TiVA) database, http://oe.cd/tiva, 2018.

In contrast to backward linkage analysis, forward linkage analysis (measured as domestic value added embodied in foreign exports) reveals a greater mixture of patterns over time (see Figure 2.5) with slightly more countries exhibiting an increasing share, even if the changes were of a very small order of magnitude for most countries. While changes in backward linkages reflect the flexibility that firms have demonstrated in their capacity to change the geographical source of supplies in response to changing in relative prices, forward linkages tend to reflect in large part the consequence of trade agreements that may have been negotiated for many years. As such forward linkages generally adjust somewhat more slowly to changing economic conditions than backward linkages.

The analysis provided in this section, being of an aggregate nature, is complemented in the next section, which explores the role played by some of the main countries, as well as three trade regions (North America ${ }^{8}$, the European Union and, East and Southeast Asia ${ }^{9}$ ) in the globalisation process of the international trade. 
Figure 2.5. Domestic value added embodied in foreign exports, as a percentage of total gross exports

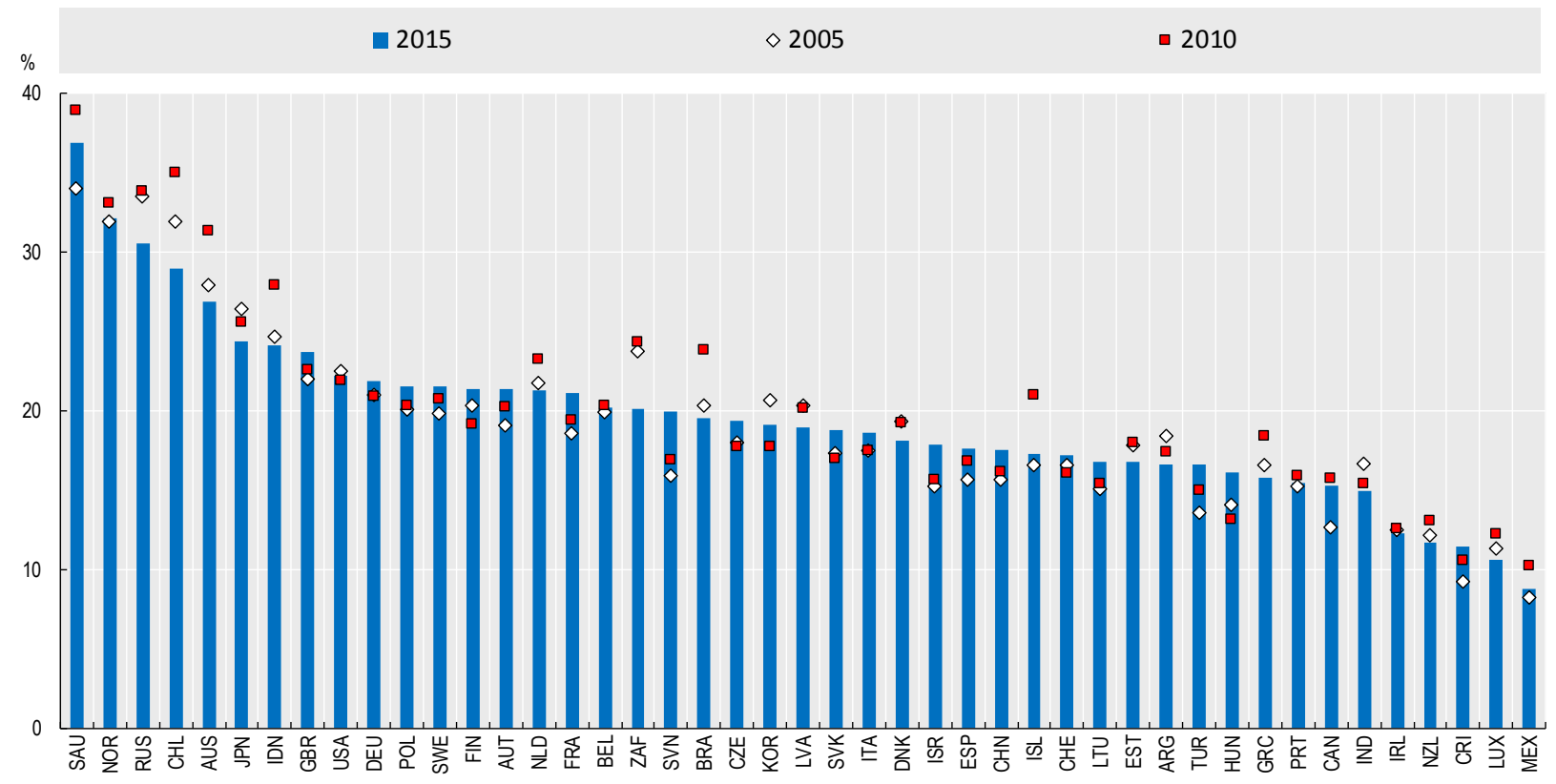

Source: OECD, Trade in Value Added (TiVA) database, http://oe.cd/tiva, 2018. 


\section{Globalisation or regionalisation?}

On the basis of analysis through to 2009, Johnson and Noguera (2017) presented a number of stylised facts, including the findings that: ${ }^{10}$

Distance is negatively correlated with changes in the bilateral ratio of value added to gross exports, so that the largest declines in value added to export ratios are concentrated among spatially proximate trading partners.

Adoption of regional trade agreements is associated with declines in the ratio of bilateral value added to gross exports. On the latter point, the authors note that the declines in the ratios are much greater in cases whether there is a customs union or common market among countries.

To determine whether or not this has been affected by the Great Financial Crisis and the continuous rise of China in global markets, this section looks more closely at the extent to which recent trends in globalisation (or de-globalisation) at the aggregate level for individual countries are a reflection of intra-regional or extra-regional trends. Indeed, the spatial focus of attention of Johnson and Noguera (2017) was on the degree of fragmentation within and outside regions, where the regions considered were North America, East and Southeast Asia and Europe, for the years 1975, 1985, 1995 and 2005. They concluded that the rise of fragmentation seems to be related to increased regionalisation of international trade. Does this still hold true?

Figure 3.1 through Figure 3.7 attempt to unravel some of the heterogeneity at the regional level by distinguishing between intra-regional and inter-regional changes in the source of the value added in the regional demand. Figure 3.1 shows regional demand for manufactured goods, while Figure 3.2 shows the same information, but considering both manufactures and business services ${ }^{11}$. As business services usually represent a large share of the economies' output and are more directed to the internal market, this leads to smaller changes, from 2005 to 2015, in the intra-regional value added shares of demand than when considering only business services. However, in both cases, a decline can be observed in the intra-regional flows for North America and the European Union (EU28), while for East and Southeast Asian demand for manufactures, an increase in the intra-regional origin of value added is apparent. This finding provides an indication of different directions taken in different regions, which can be explained in part by the continuous rise of China in the international market as well as in the continued growth of its domestic economy.

Looking at the internal composition of the regional demand in Europe, one can observe small changes within the European Union, with Italy and France loosing participation, the United Kingdom remaining stable while Germany and EU13 ${ }^{12}$ increased their shares.

For intra-regional trade in East and Southeast Asia, China's increasing role is very evident, with its intra-regional share more than doubling, from $22.4 \%$ to $55.8 \%$ when considering both manufactures and business services, and from $31.4 \%$ to $63.3 \%$ when considering manufactures only. On the other hand, a major decrease in participation in intra-regional trade is observed for Japan with its share declining by more than half in both cases, from $55.3 \%$ to $23.6 \%$ in manufactures and business services and from $45.3 \%$ to $16.2 \%$ in manufactures only. Korea and Chinese Taipei show a small decline in their share while the rest of East and Southeast Asia shows a small increase. 
For inter-regional demand, the patterns are different for each region analysed: a) for North American demand, there is an increase in shares of value added originating from East and Southeast Asia, mainly offset by a decrease in the intra-regional share: b) for the Europe Union there is an increase in the shares of all inter-regional supply while the intra-regional share has fallen; and c) for East and Southeast Asia demand, when considering both manufactures and business services there are small changes in the shares of originating regions - however, when considering manufactures only, there is reduction in the shares of demand originating from other regions. Overall, these changes point to an increase in the demand for intra-regional goods in East and Southeast Asia, and an increase in the share of this region as a supplier to the other regions; this result is strongly influenced by the size and the continuous growth of China domestic economy, and especially by the growth of its exports and imports.

Figure 3.1. Regional demand for manufactured goods, 2005 and 2015, by economy or region of value added origin, percentage shares of total

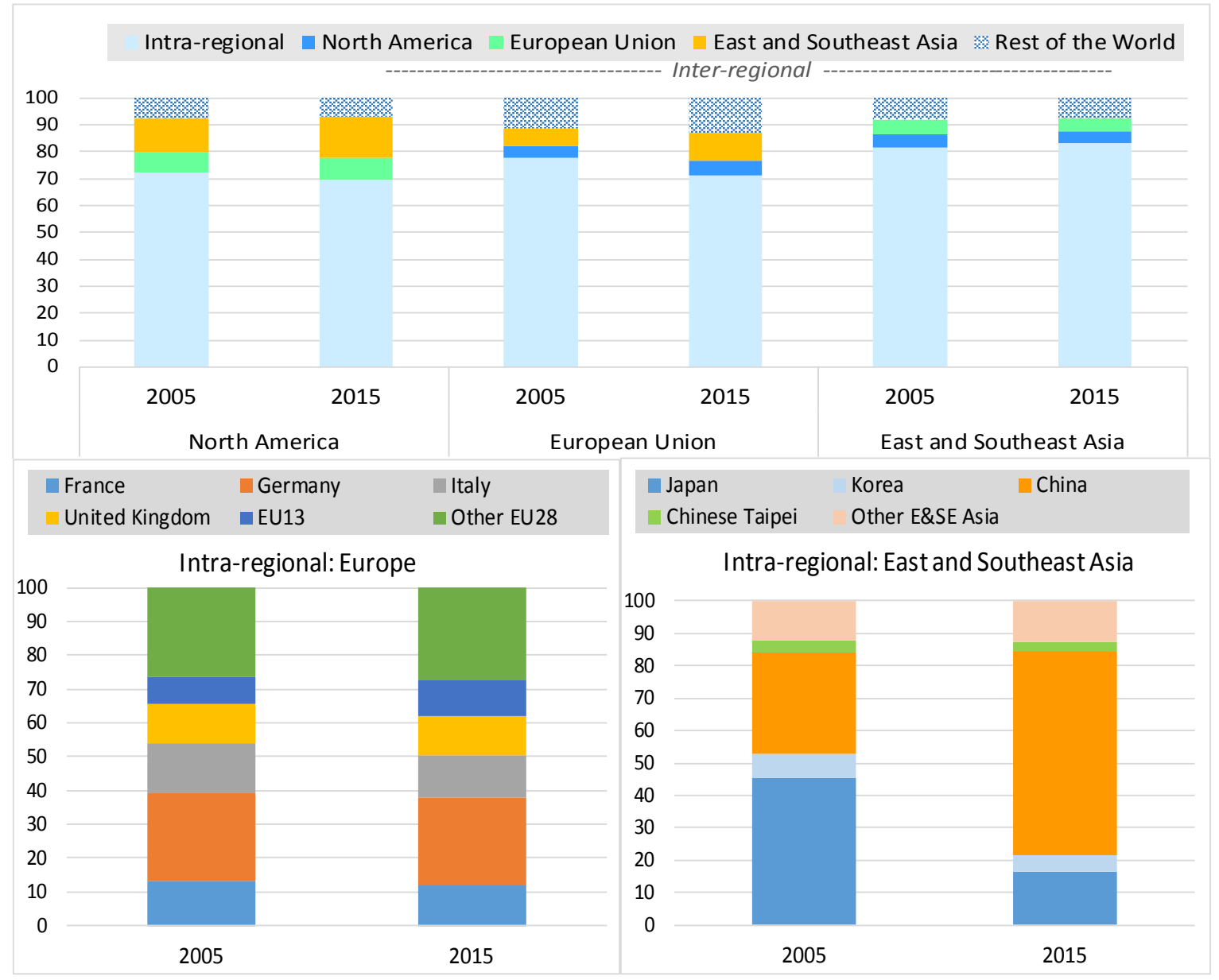

Source: OECD, Trade in Value Added database, http://oe.cd/tiva, 2018, Origin of value added in final demand 
Figure 3.2. Regional demand for manufactured goods and business services, 2005 and 2015, by economy or region of value added origin, percentage shares of total

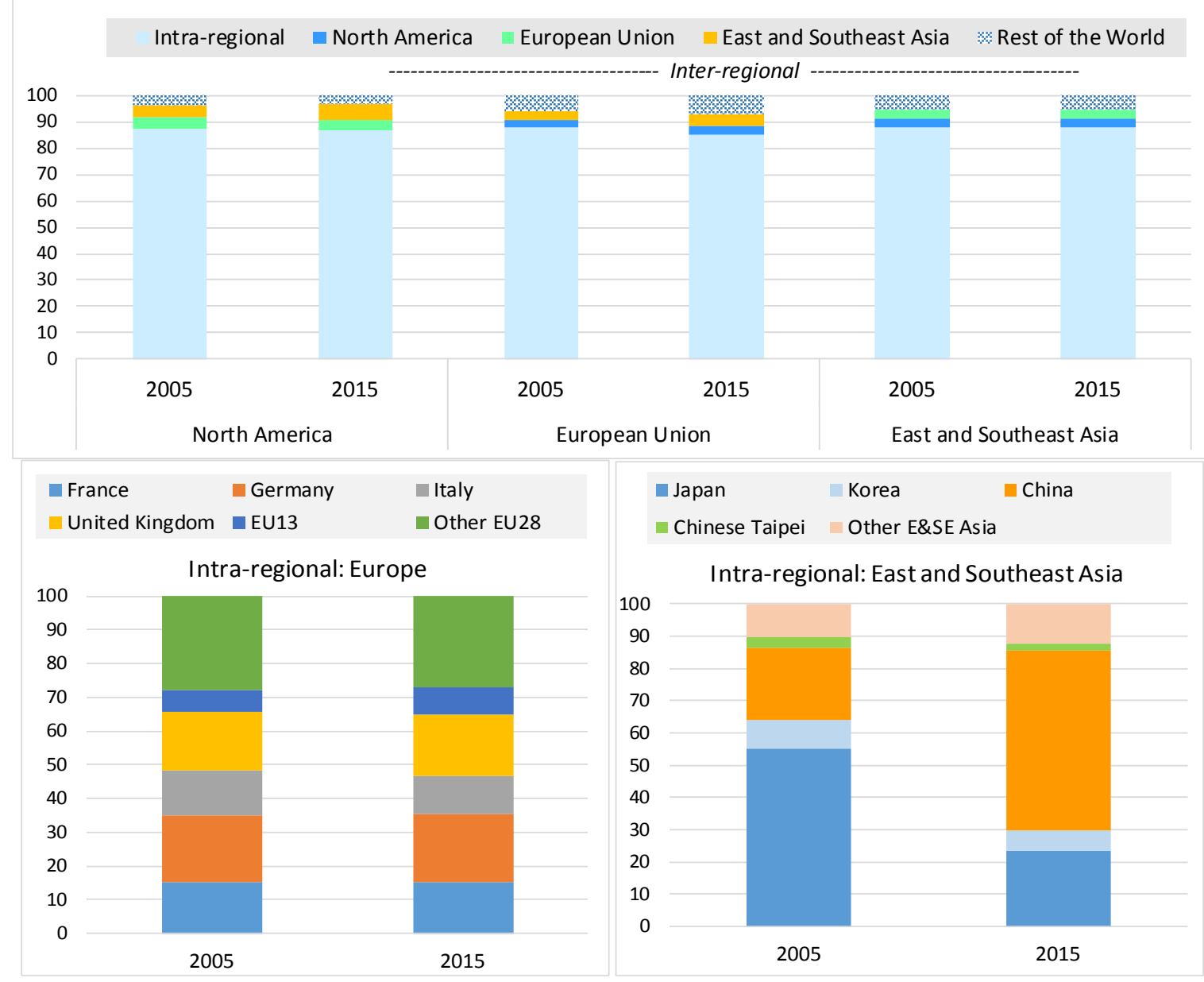

Source: OECD, Trade in Value Added database, http://oe.cd/tiva, 2018, Origin of value added in final demand

The previous analysis considers the total demand of the countries, sourced either from the domestic market or the imports from other countries, either intra or inter-regional. To actually see if countries are trading more intra- or inter-regionally, the values presented in Figure 3.3, Figure 3.4, Figure 3.5 and Figure 3.6 refer only to the trade of major players in international trade, i.e. a) France, Germany and United Kingdom in the European Union; b) the United States in North America; and c) Japan, Korea and China in East and Southeast Asia. Figure 3.3 shows the origin of foreign value added in domestic final demand (i.e. from the import perspective), and Figure 3.4 shows the domestic value added in foreign final demand (i.e. from the export perspective). Taken in combination these figures allow a better understanding of how the countries are integrated in the international market, and the extent to which this integration is intra-regional or inter-regional (Rest of the World ROW). Figure 3.3 and Figure 3.4 considers both manufactures and business services, while Figure 3.5 and Figure 3.6 considers manufactures only. 
Figure 3.3. Origin of foreign value added in domestic final demand for manufactured goods and business services, intra-regional versus extra-regional (ROW) origin, selected countries, 2005 to 2015, USD Millions and percentage shares
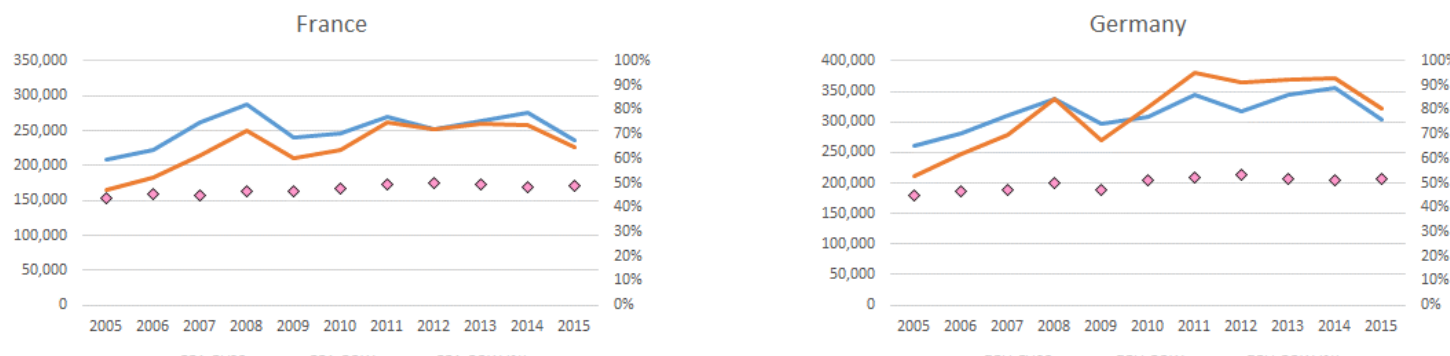

—FRA-EU28 —FRA-ROW \& FRA-ROW (\%)

United Kingdom

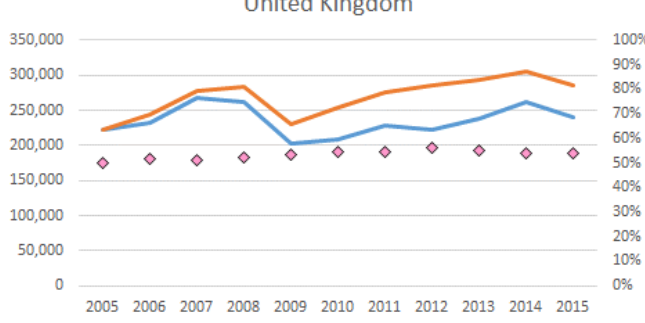

—DEU-EU28 — DEU-ROW \& DEU-ROW (\%)

USA

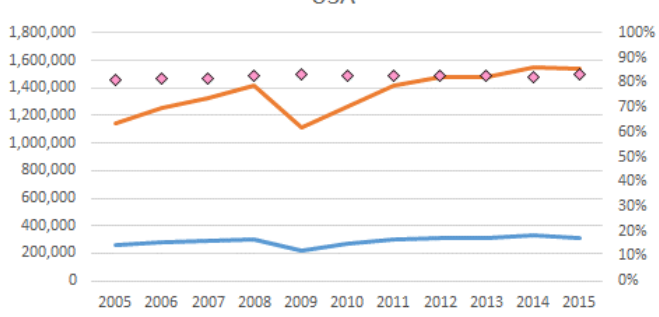

—GBR-EU28 G GBR-ROW $\diamond$ GBR-ROW (\%)

- USA-N. America

Japan

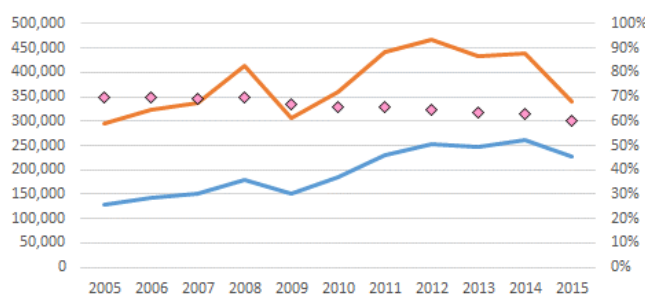

Korea

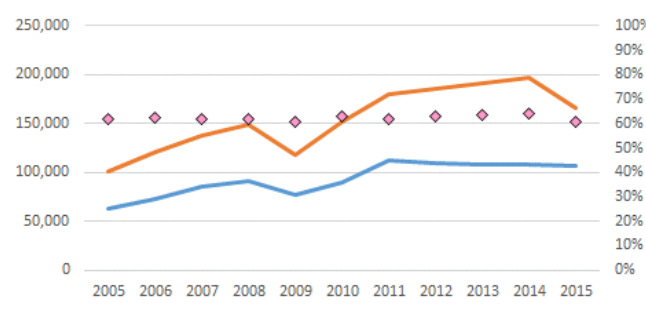

—JPN-Asie —JPN-ROW $\diamond$ JPN-ROW (\%)

—KOR-Asia KOR-ROW \& KOR-ROW (\%)

China

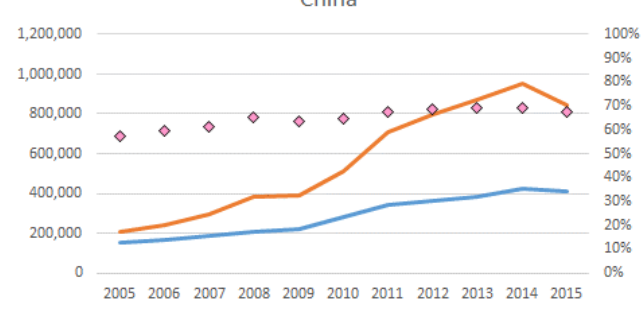

- CHN-Asia - CHN-ROW $\triangle$ CHN-ROW $(\%)$

Source: Estimation based on OECD's Inter-Country Input-Output (ICIO) Database, 2018. 
Figure 3.4. Domestic value added in foreign final demand for manufactured goods and business services, intra-regional versus extra-regional (ROW) demand, selected countries, 2005 to 2015, USD Millions and percentage shares
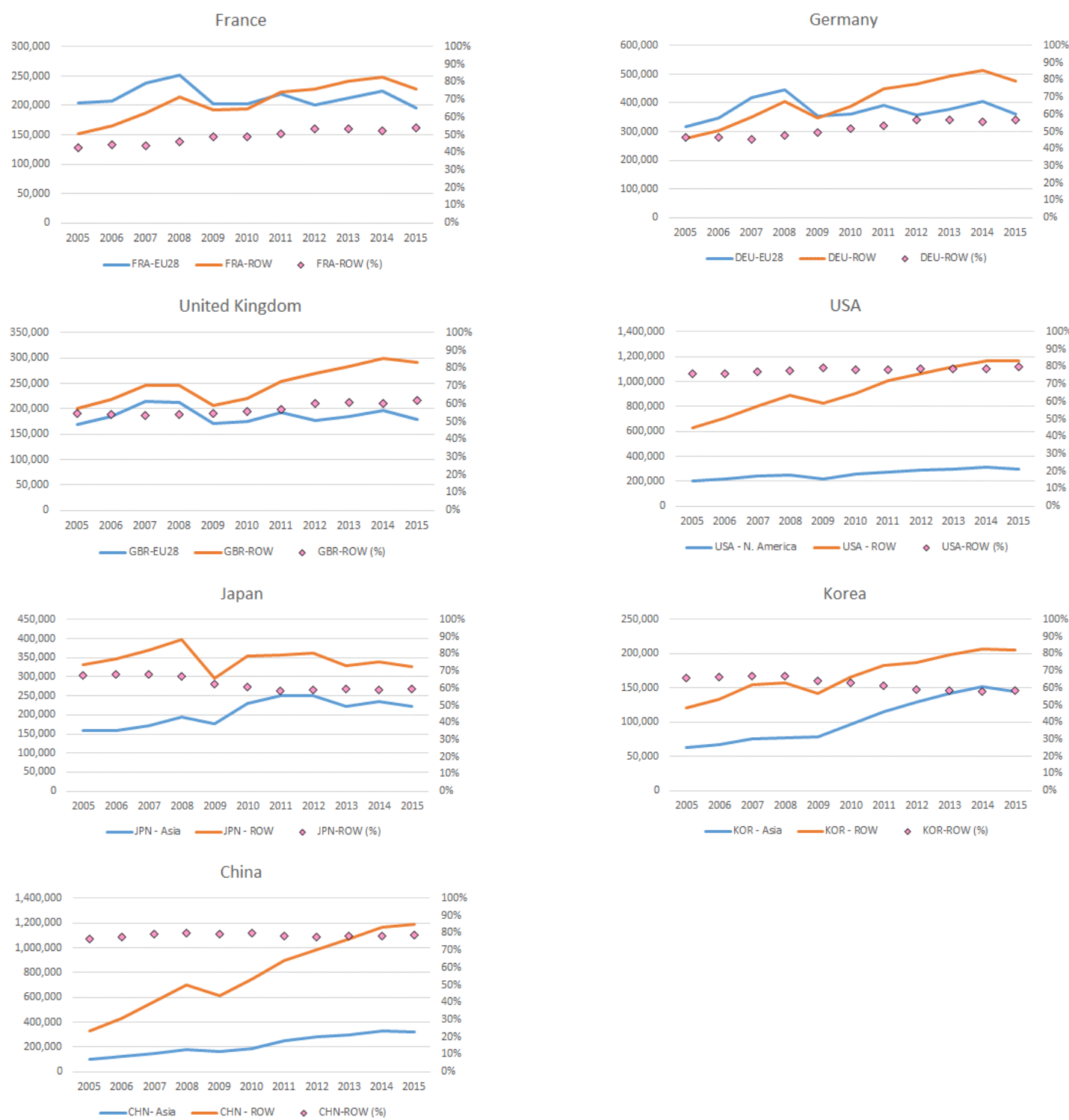

Source: Estimation based on OECD's Inter-Country Input-Output (ICIO) Database, 2018. 
Figure 3.5. Foreign value added in domestic final demand for manufactured goods, intra-regional versus extra-regional (ROW) origin, selected countries, 2005 to 2015, USD Millions and percentage shares
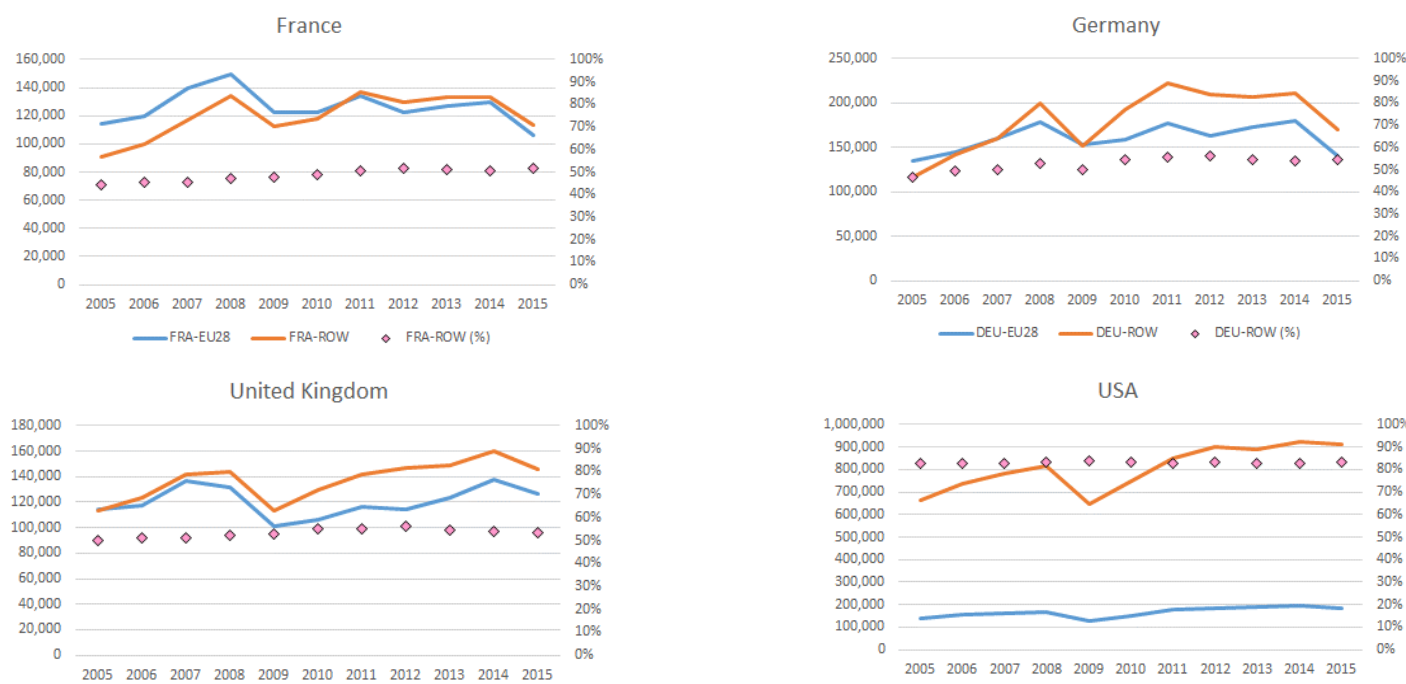

$100 \%$
$90 \%$
$80 \%$
$70 \%$
$60 \%$
$50 \%$
$40 \%$
$30 \%$
$20 \%$
$10 \%$
$0 \%$

—GBR-EU28 —GBR-ROW \& GBR-ROW (\%)

Japan
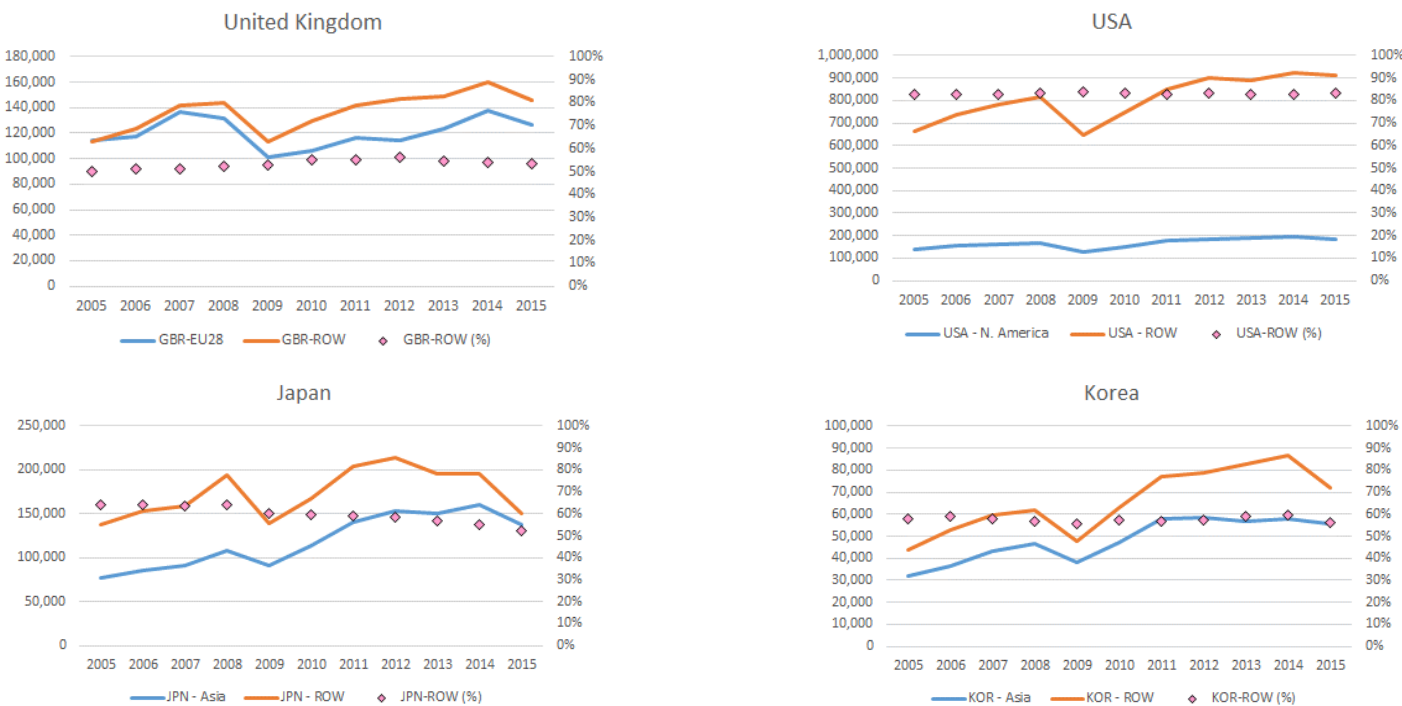

China

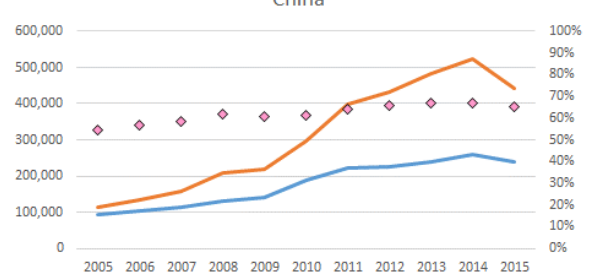

-CHN-ASia -CHN-ROW $\triangle$ CHN-ROW(\%)

Source: Estimation based on OECD's Inter-Country Input-Output (ICIO) Database, 2018 
Figure 3.6. Domestic value added in foreign final demand for manufactured goods, intra-regional versus extra-regional (ROW) demand, selected countries, 2005 to 2015, USD Millions and percentage shares
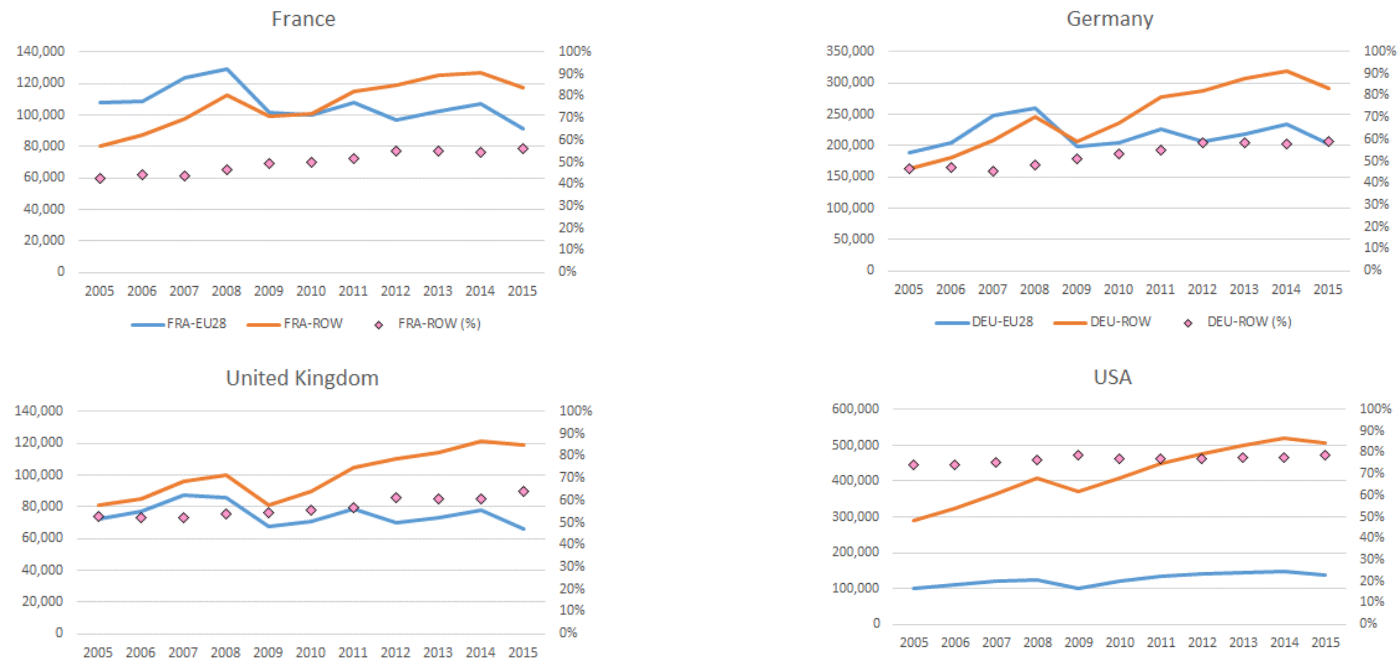

-DEU-EU28 —DEU-ROW @ DEU-ROW (\%)

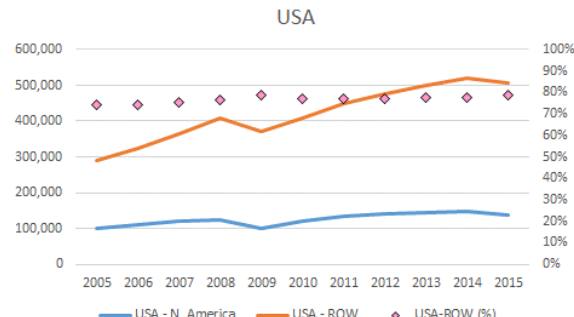

—GBR-EU28 —GBR-ROW \&GBR-ROW (\%)

Japan
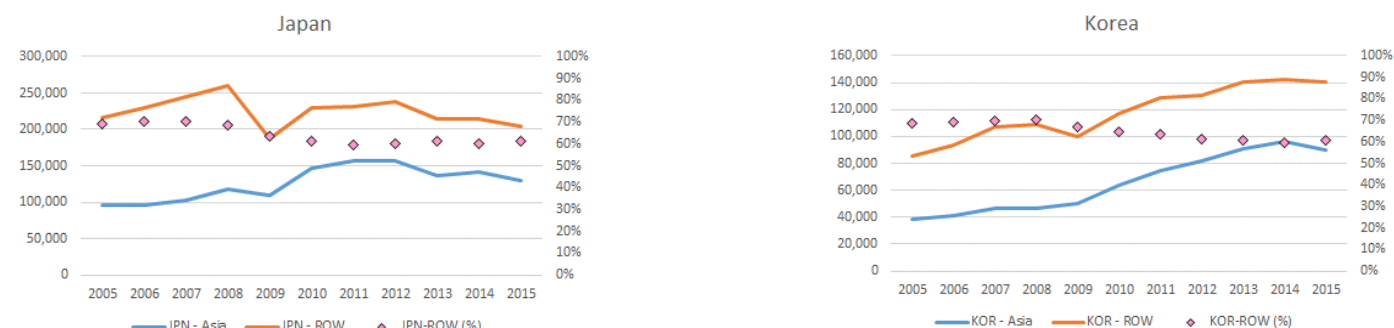

—JPN-Asia —JPN-ROW $\diamond$ JPN-ROW $(\%)$

China

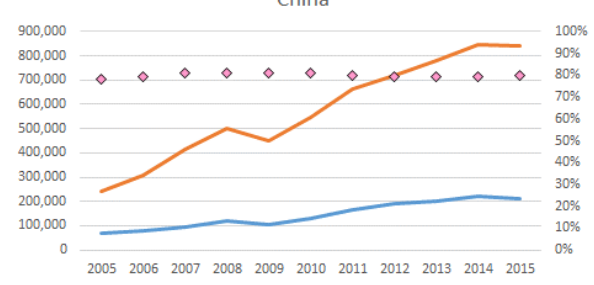

CHN-Así - CHN-ROW \& CHN-ROW(\%)

Source: Estimation based on OECD's Inter-Country Input-Output (ICIO) Database, 2018 
For the selected countries in North America and European Union, there is an increase in inter-regional integration from 2005 to 2015, with some oscillations, in both exports and imports of value added, and hence a decrease in role of the intra-regional production in meeting final demand. This result is influenced a great deal by the fact that China is considered extra-regional in these cases.

For the selected East and Southeast Asian countries, the trends are different, but, also greatly influenced by the trade with China. Japan and Korea's inter-regional relationships have diminished a little, as the importance of the intra-regional trade for these countries has increased - especially prominent being the increase in the dependence of their trade with China. On the other hand, given its economic size, one observes that at the same time that China increases the share of the intra-regional trade of the other economies in East and Southeast Asia. China's economy is large enough to record an increase in its share of trade in value added with the rest of the world.

Another important question concerns the destination of intermediate products exported by countries. Are they being incorporated in products for final consumption within the region? Do they return to the exporting country embodied in imports or are they embodied in exports for extra-regional final consumption? Figure 3.7 shows the final destination of intermediate exports by importer region, e.g. intermediate goods exported by France to the European Union can end up being embodied in final goods sold in France, other European Union countries or, the rest of the world.

The selected European countries (France, Germany, and the United Kingdom) have similar patterns in terms of the final destination of intermediates: between $4 \%$ and $6 \%$ of the intermediates exported to the European Union return to these countries, $70 \%$ to $75 \%$ stay within other EU countries, while $20 \%$ to $25 \%$ are embodied in goods exported to the rest of the world. For extra-regional exports, between $1 \%$ and $2 \%$ return to the exporting country, $5 \%$ to $8 \%$ go to other countries in the EU, while $90 \%$ to $95 \%$ remain outside the region. Extra-regional exports of intermediates that return to the exporting country and region are lower than intra-regional exports that end up outside the EU. As a result, from the exporter side, these countries are exporting more to the rest of the world than reported trade statistics may suggest.

For the United States, of the intermediates exported to the other North American countries (Canada and Mexico), around 30\% returns to the US, while around 57\% stays in the region. For the extra-regional exports, about $6 \%$ returns to the US, $1 \%$ goes to the rest of North American and $93 \%$ remains to meet extra-regional demand. For the US in particular, extraregional exports that return to the exporting country are greater than the exports to regional neighbours that end up further afield; the US is exporting less to the rest of the world than reported trade statistics may suggest.

Among the selected countries in East and Southeast Asia, China has the highest share of inter-regional exports of intermediates that return to the country. In 2015 , about $10 \%$ of the value added returned to China, $63 \%$ remained in the region and $27 \%$ was exported to the rest of the world. Japan and Korea have similar patterns for intra-regional exports, with about $68 \%$ remaining in other countries in the region. For Korea, around $1.5 \%$ of intraregional exports return, while for Japan, between 3\% and $4 \%$. For all three countries, around one-third of intra-regional exports are subsequently embodied in exports to the rest of the world. For extra-regional exports of intermediates, the great majority remain outside the region, around $95 \%$. 
These results help shed some light on what is happening in terms of evolution in international trade and the interconnections among countries; the central role played by China is clearly evident in explaining the results. The increased dependence and integration among the East and Southeast Asia economies is a result of organisation within the region to produce goods and services to fulfil the growing extra-regional demand and Chinese domestic demand.

It is striking how one country, China, has influenced the way international trade has evolved in the last 10 to 20 years. Despite a decreasing share of exports going to other East and Southeast Asian economies, China's volume of trade is sufficiently large to make the region, and the rest of the world more generally, highly dependent on the Chinese economy. This transformation reflects in large part the development of the Chinese economy in terms of size and technology. Looking ahead, factors like new technology and intangibles ${ }^{13}$ will continue to have a crucial role in shaping the evolution of international trade.

The next section focuses of how the intensity of trade has been changing in four sectors that are major players in the global trade. They have been chosen because they represent different aspects of trade in goods, ranging from textiles and apparel to motor vehicles, chemicals and, computers and electronics. Each of these sectors has a very distinctive set of trading patterns and are sectors that have experienced some of the most important changes in the structure of their GVCs over the past few decades. 
Figure 3.7. Final destination of intermediate exports by importing region, intraregional versus extra-regional, selected countries, 2005 to 2015, as a percentage share of total intermediate export
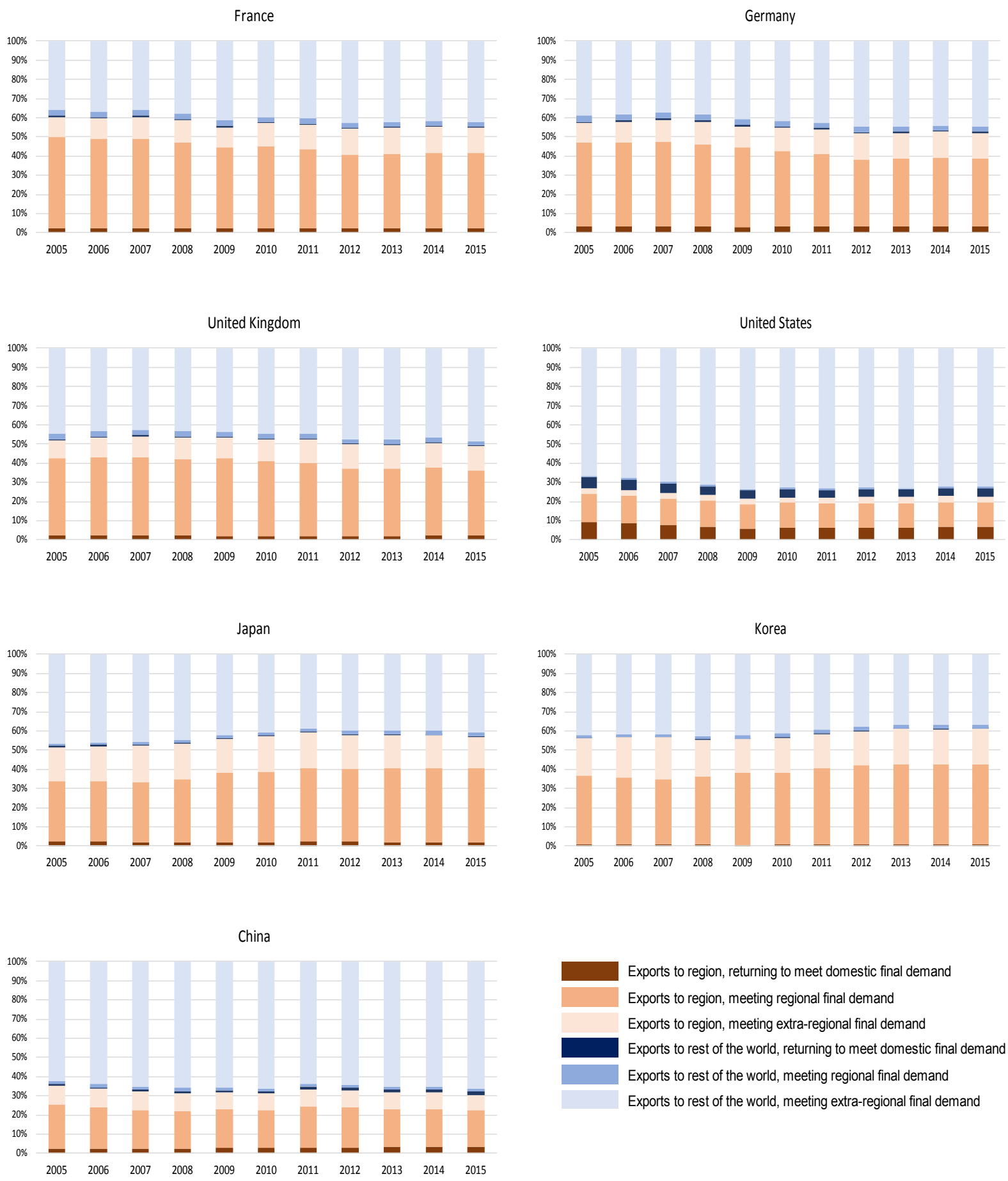

Source: Estimations based on OECD’s Inter-Country Input-Output (ICIO) Database, 2018 


\section{Sectoral changes}

For the sectoral analysis, four highly fragmented sectors, Textiles and apparel, Chemicals and pharmaceuticals, Computer, electronic and optical products (or "ICT and electronics") and, Motor vehicles, were chosen for more detailed inspection in order to identify whether there were pronounced differences in terms of increasing or decreasing fragmentation and changing spatial linkages. Before proceeding to the analysis of these four individual sectors, Figure 4.1 explores the sectoral changes at the world level (global average) over the period between 2005 and 2015, for shares of foreign value added embodied in domestic final demand, split into the origin of the value added: OECD and non-OECD countries. Seven sectors recorded declines in foreign value added shares in domestic final demand - Motor vehicles, Coke and petroleum, Mining (energy, non-energy and services) and Agriculture being the most prominent. For the other sectors, there was increasing dependence. For some sectors, the share of value added accounted for by nonOECD countries was very large (e.g. textiles). Figure 4.2 highlights these changes in terms of the OECD countries average.

Figure 4.1. Foreign value added embodied in domestic final demand by sector, global average, 2015, as a percentage of total domestic demand

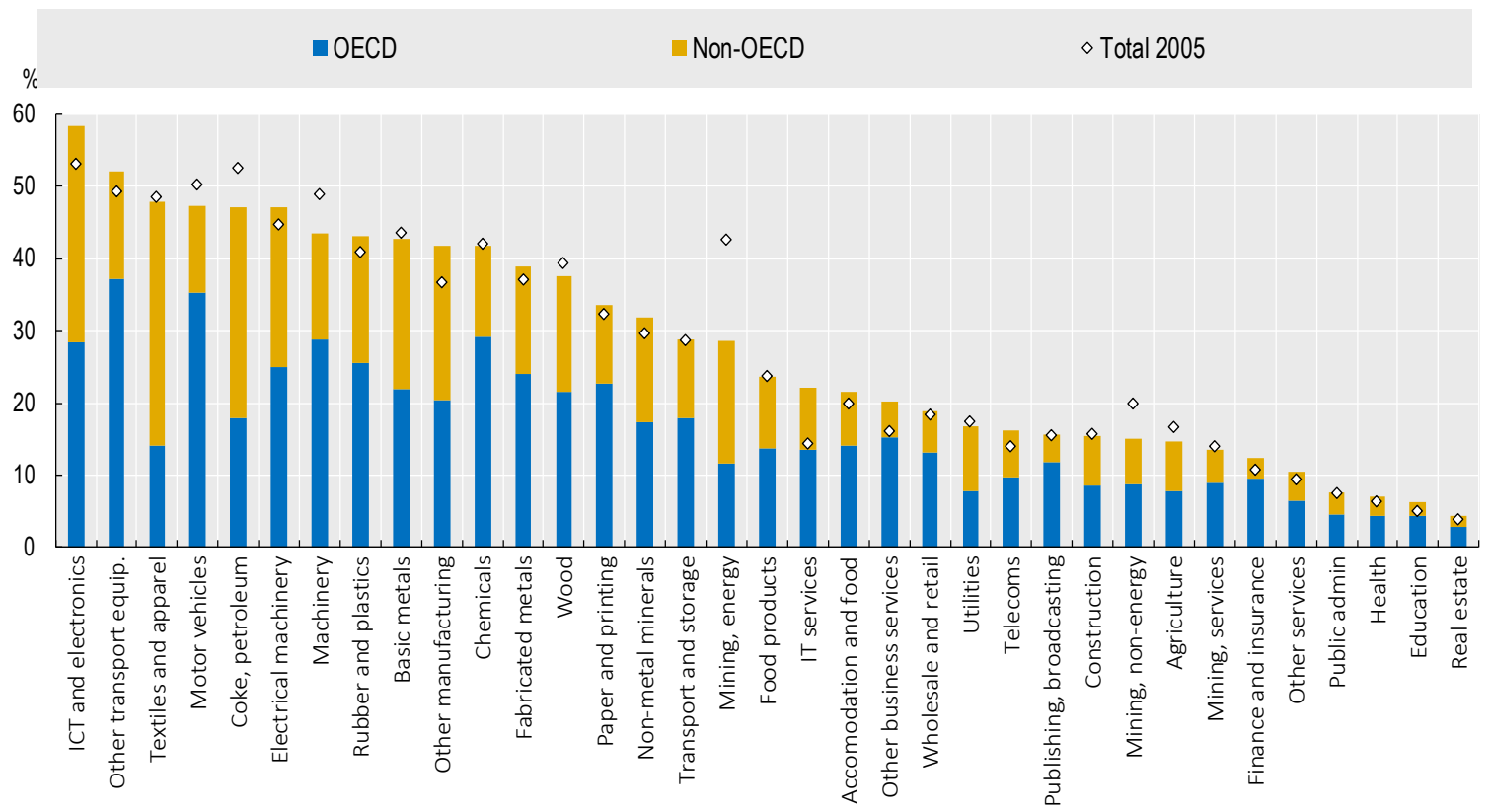

Source: OECD, Trade in Value Added database, http://oe.cd/tiva, 2018, Origin of value added in final demand 
Figure 4.2 Foreign value added embodied in domestic final demand, by sector, OECD average, 2015, as a percentage of total domestic demand

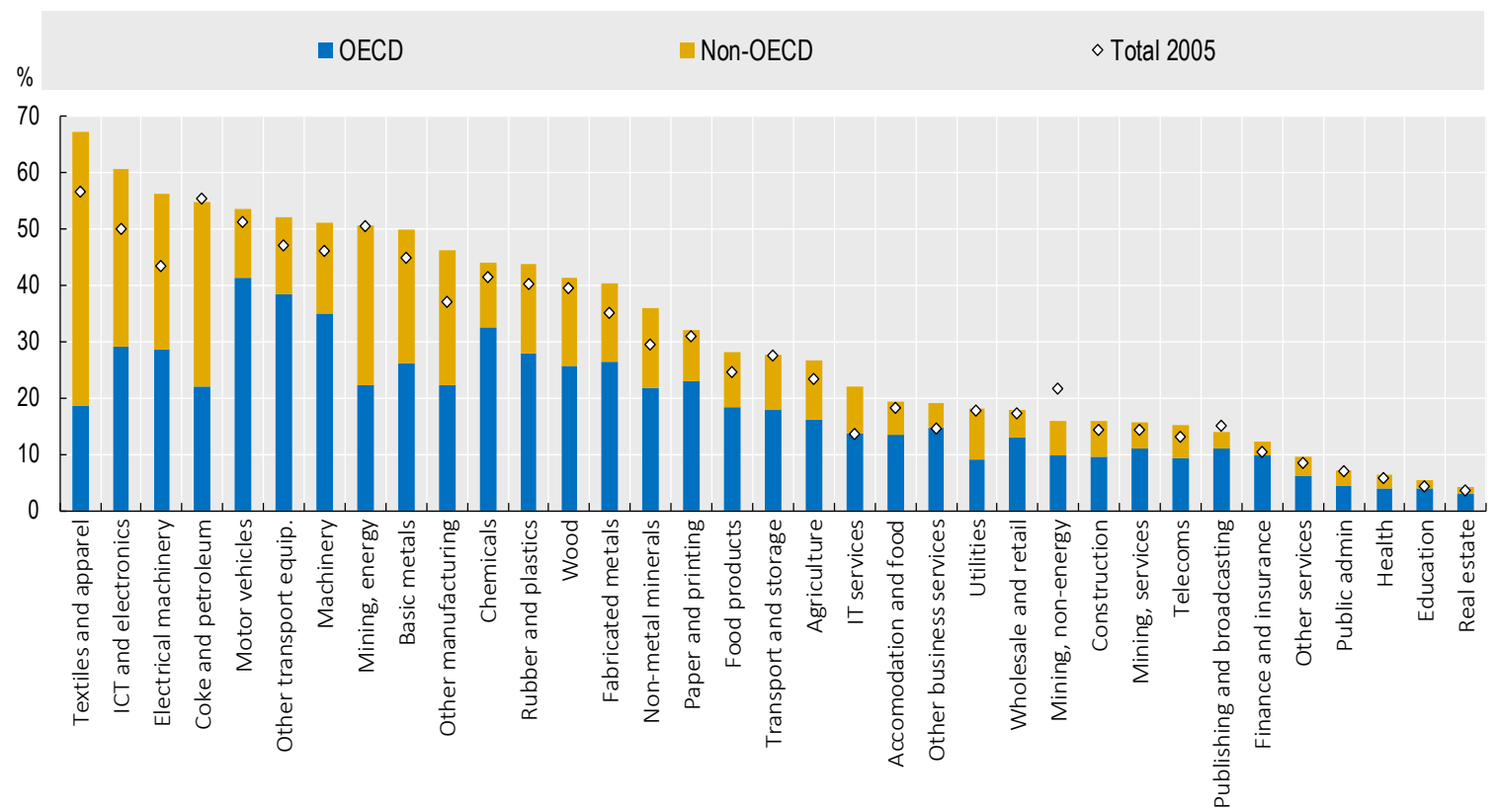

Source: OECD, Trade in Value Added database, http://oe.cd/tiva, 2018, Origin of value added in final demand

\subsection{Textiles and apparel}

Figure 4.3 shows on the left where the valued added of Textiles and apparel is consumed while in the right shows where it is produced, one can see that the European Union (EU28) shares of final demand and value added production witnessed some of the largest declines - around 10 and 12 percentage points respectively. The North American share of global final demand declined by 7 percentage points with a similar decrease of 6 percentage points in the share of value added originating there. China accounted for most of the gains; final demand and value added increased by over 7 and 15 percentage points respectively. There were also gains in the rest of the world of 7 and 3 percentage points respectively. Over a ten-year period, these represent major shifts in both the location of value added and demand. In the case of East and Southeast Asia, China's share increased significantly from $49 \%$ to $70 \%$, primarily at the expense of Japan and Korea. 
Figure 4.3. Global demand for Textiles and apparel, by country or region of final demand and origin of value added, percentage shares of total, 2005 and 2015

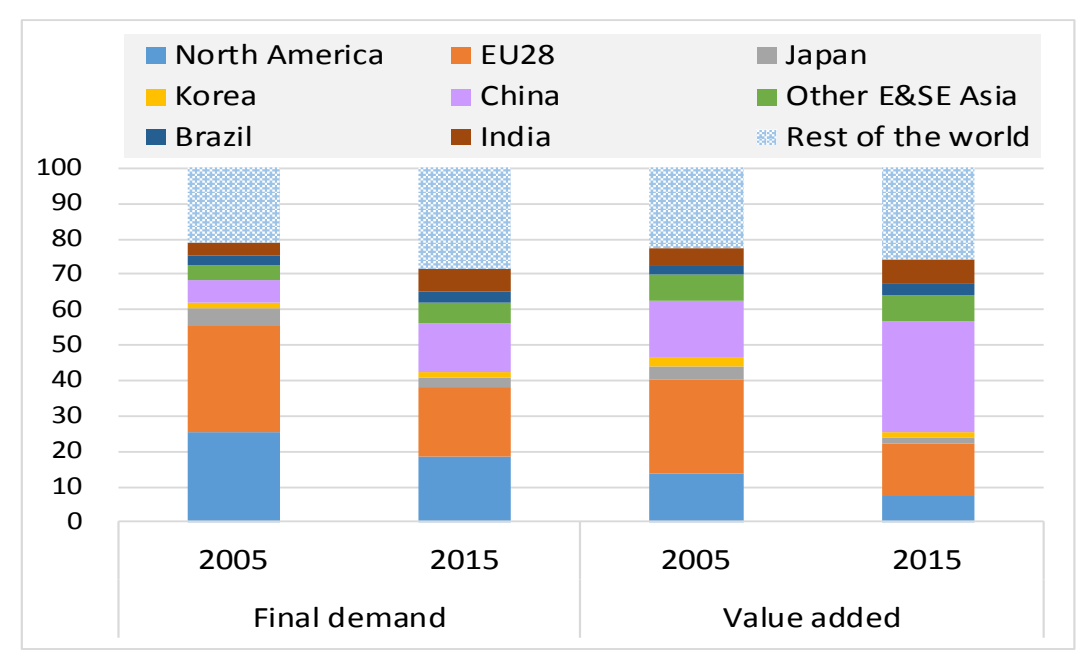

Source: OECD, Trade in Value Added database, http://oe.cd/tiva, 2018, Origin of value added in final demand

Figure 4.4. . Regional demand for Textiles and apparel by economy or region of value added origin, percentage shares of total, 2005 and 2015

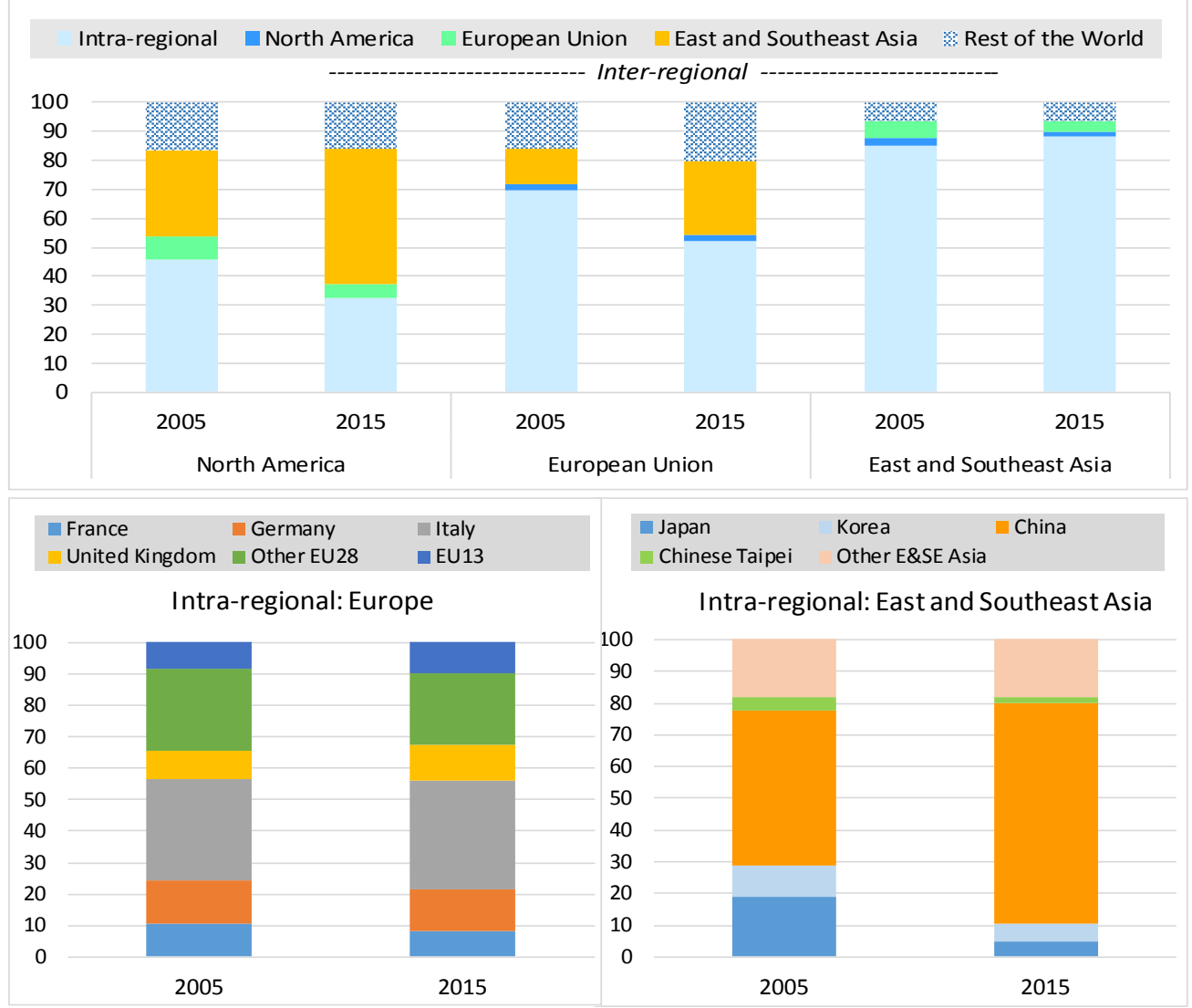

Source: Trade in Value Added database, http://oe.cd/tiva, 2018, Origin of value added in final demand 
Figure 4.5 presents the individual country data that reflect these macroeconomic changes with an increasing dependence on foreign value added although there was some heterogeneity in the mix of sources of this foreign value added. The shares across major regions (EU 28, North America, China etc.) tended not to be concentrated in one particular external region, perhaps reflecting consumers' increasing love of variety in demand for textiles and related products. Even in North America, Figure 4.4, 32\% of the demand (in terms of value added) is intra-regional but this has declined from $46 \%$ in 2005 ; the change in location can be explained by the share of over $46 \%$ (growing from $30 \%$ in 2005) that is sourced in East and Southeast Asia while rest of the world share has remained constant at around $16 \%$. For Europe, a similar pattern of spatial exchange can be seen, with the intraregional share declining from $70 \%$ to $52 \%$.

\section{Figure 4.5. Foreign value added embodied in domestic demand for Textiles and apparel by source region, as a percentage of total domestic demand}

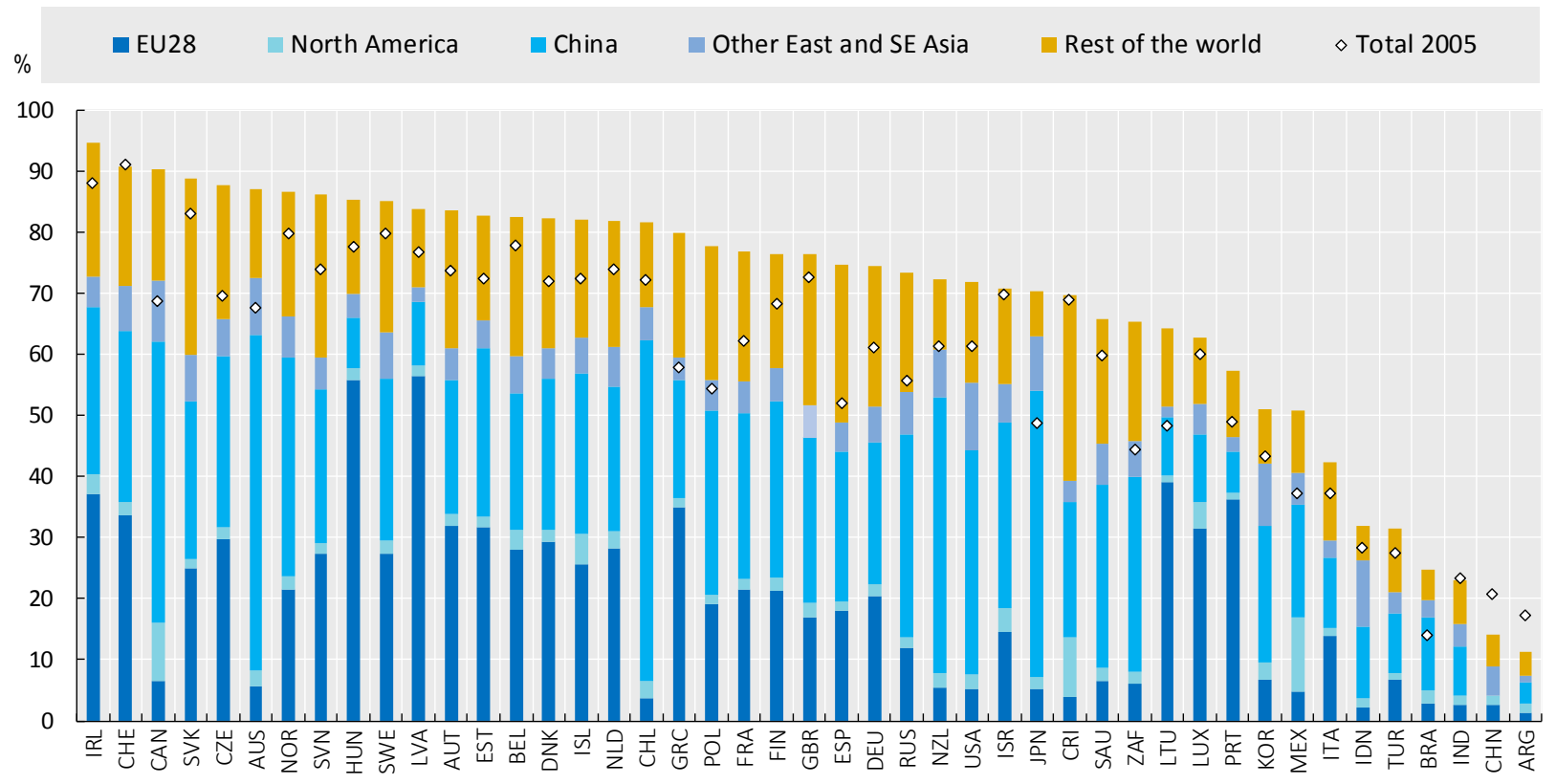

Source: Trade in Value Added database, http://oe.cd/tiva, 2018, Origin of value added in final demand

\subsection{Chemical and pharmaceutical products}

In contrast to the textiles industry, the changes recorded in the Chemicals and pharmaceutical sector were much smaller (Figure 4.6). North American share of global final demand declined from $36 \%$ to $33 \%$ and its share of value added dropped from $31 \%$ to $29 \%$. The decline in the European Union was more pronounced with final demand declining by 12 percentage points (from $32 \%$ to $20 \%$ ) with a loss of value added share of more than 9 percentage points ( $32 \%$ to $23 \%$ ). Most of the positive changes in final demand were recorded in China (with a gain from 6\% to 16\%). Similarly for value added there was an increase of 10 percentage points in China's share (see Figure 4.6). 
Figure 4.6. Global demand for Chemical and pharmaceutical products, by country or region of final demand and origin of value added, percentage shares of total, 2005 and 2015

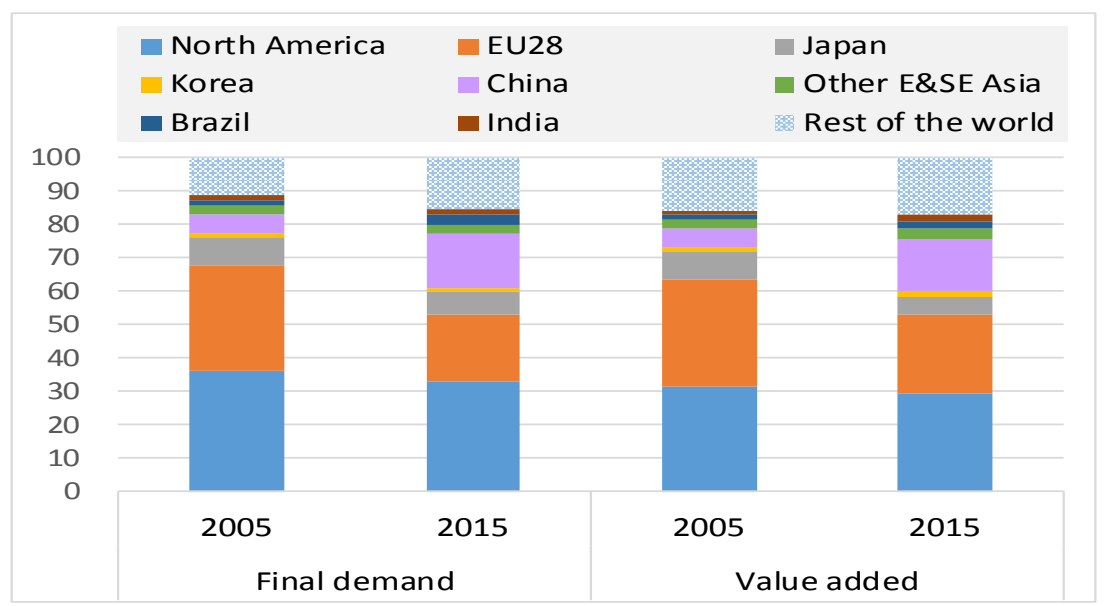

Source: OECD, Trade in Value Added database, http://oe.cd/tiva, 2018, Origin of value added in final demand

Figure 4.7. Regional demand for Chemical and pharmaceutical products, by economy or region of value added origin, percentage shares of total, 2005 and 2015

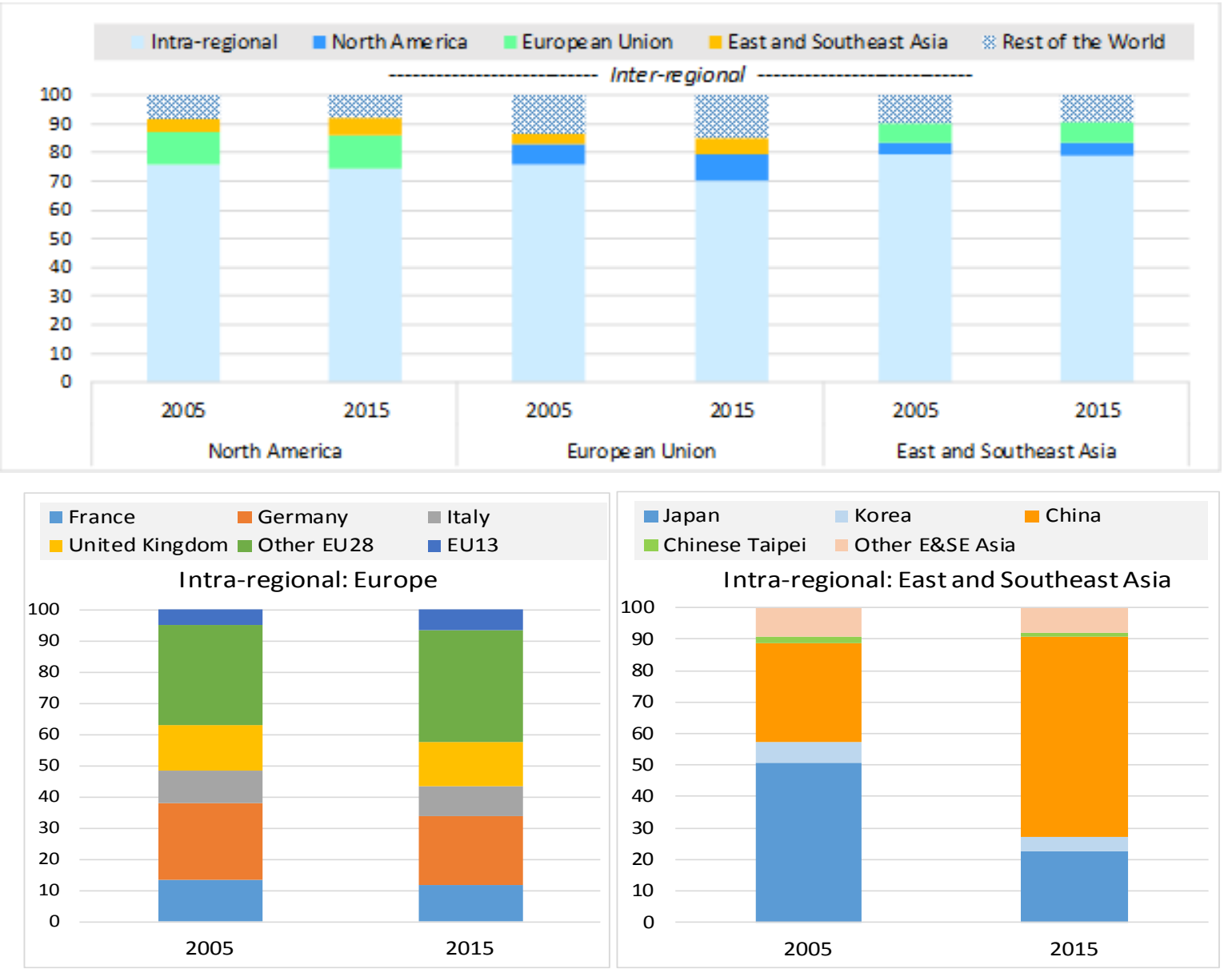

Source: OECD, Trade in Value Added database, http://oe.cd/tiva, 2018, Origin of value added in final demand 
The changes at the country level (Figure 4.8) show that about half of the countries decreased their dependence on foreign sources of foreign value added in domestic final demand while the other half increased it from their 2005 values. The geographical dependence was still dominated by the imported demand from the region in which the individual country was located, such that this industry is more regionalised in sourcing than the textiles sector. China's share in this case was modest except from its own domestic demand. For the European Union, Figure 4.7, there was a decline from $76 \%$ to $70 \%$ in the percentage of the demand sourced within the region. The equivalent decline in North America was just over 1 percentage point. Some of the more dramatic changes occurred in East and Southeast Asia where Japan experienced a declining share of intra-regional demand from $51 \%$ to $23 \%$; in contrast, China's share increased from $31 \%$ to $64 \%$.

Figure 4.8. Foreign value added embodied in domestic demand for Chemical and pharmaceutical products, by source region, 2015, as a percentage of total domestic demand

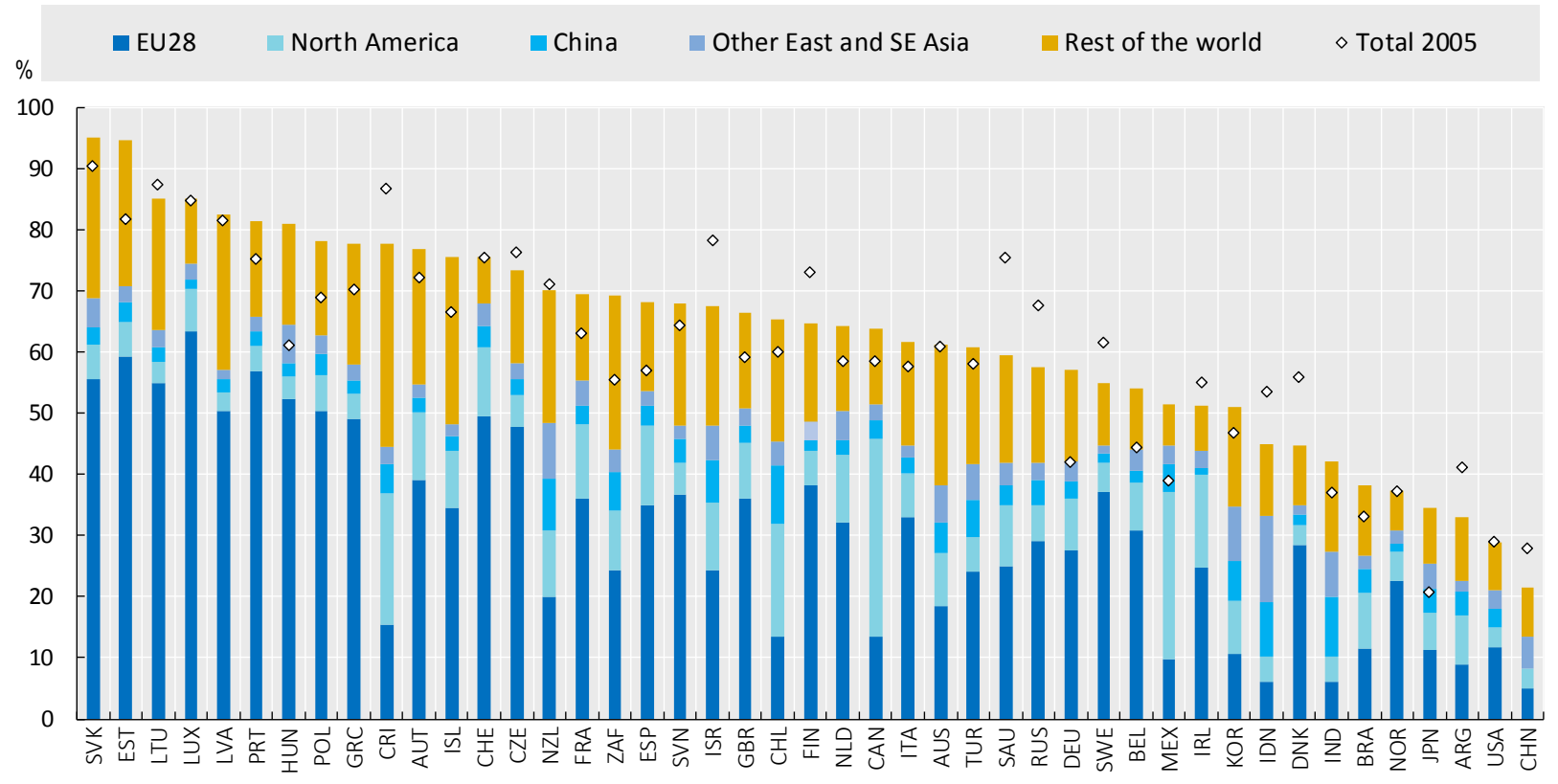

Source: Trade in Value Added database, http://oe.cd/tiva, 2018, Origin of value added in final demand

\subsection{Computer, electronic and optical products}

The Computer, electronic and optical products sector experienced some significant shifts in the geographical origin of demand or the location of value added (Figure 4.9 and Figure 4.10). North America's share of demand declined from $37 \%$ to $21 \%$ while China's share increased from $6 \%$ to $20 \%$. The other major increase took place in the rest of world with its shares increasing from $11 \%$ to $19 \%$. The share for the European Union, Korea and Japan all declined with Japan's decline the most prominent of these three. In terms of value added, the reallocation followed similar patterns to those of final demand; North America's share declined by 11 percentage points to $17 \%$ while China's increased to $28 \%$, an 18 percentage point increase. The European Union's and Japan's shares declined by 5 and 8 percentage points but Korea's share was stable. Value added demand in the rest of the world increased by almost 4 percentage points. 
Figure 4.9. Global demand for Computer, electronic and optical products, by country or region of final demand and origin of value added, percentage shares of total, 2005 and 2015

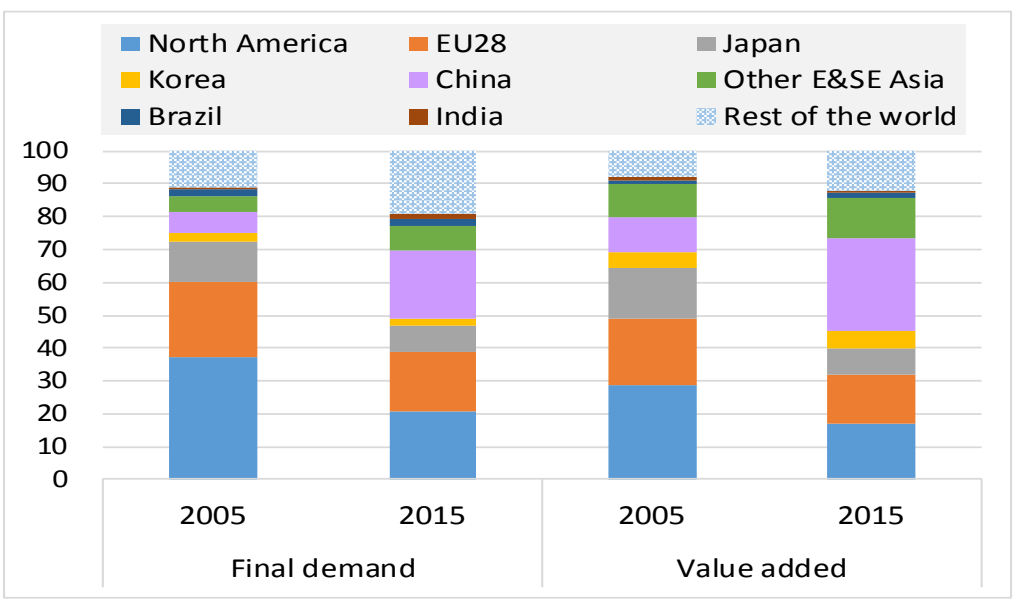

Source: OECD, Trade in Value Added database, http://oe.cd/tiva, 2018, Origin of value added in final demand

Figure 4.10. Regional demand for Computer, electronic and optical products, by economy or region of value added origin, percentage shares of total, 2005 and 2015
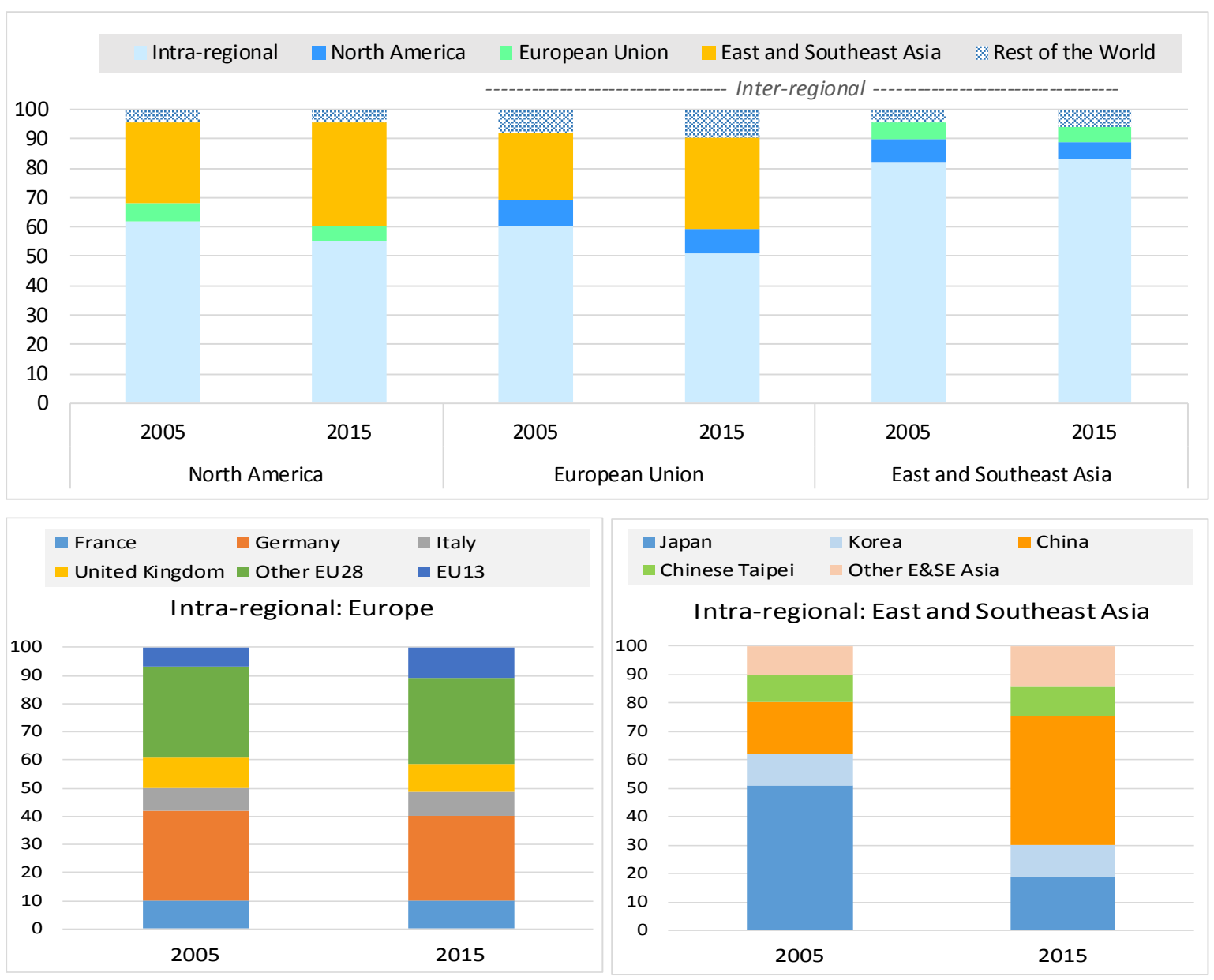

Source: OECD, Trade in Value Added database, http://oe.cd/tiva, 2018, Origin of value added in final demand 
Figure 4.11. Foreign value added embodied in domestic demand for Computer, electronic and optical products, by source region, 2015, as a percentage of total domestic demand

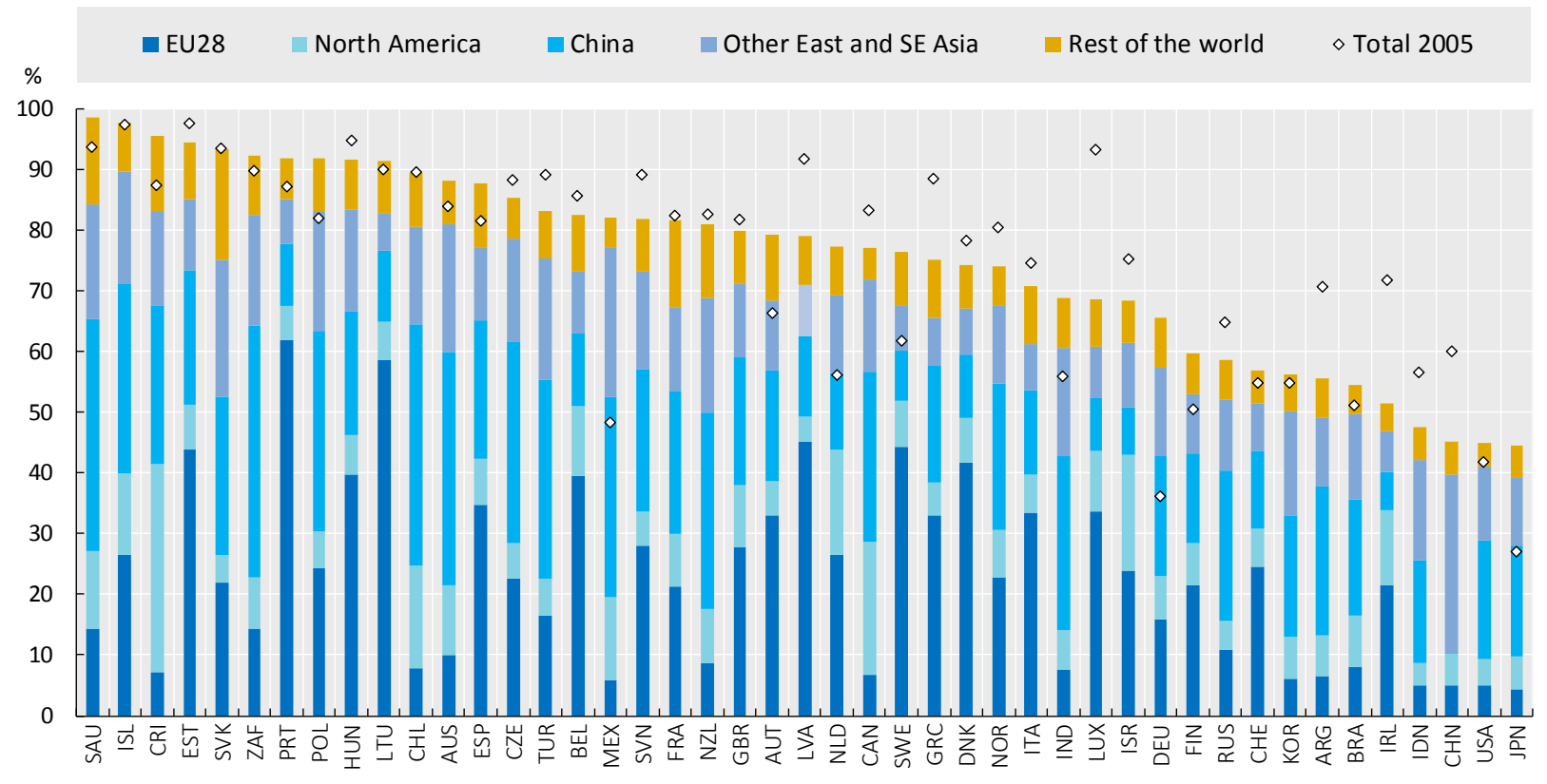

Source: Estimation based on OECD's Inter-Country Input-Output Database (2018) 


\section{Box 4.1. The Case of "Information industries"}

While indicators for the manufacture of Computer, electronic and optical products (ISIC Rev.4 Division 26) have been presented above, given the importance of ICT in general, this Box considers the broader "information industries" sector encompassing both manufacturing and related ICT services (Divisions 58 to 63).

Between 2005 and 2015, the value added sourced in the United States to meet US final demand for "information industries" products increased from $82 \%$ to $85 \%$. In China, the equivalent share increased from 59\% to $70 \%$ while for the European Union (EU28), the share fell from $82 \%$ to $78 \%$. Looking at the origins of foreign content of domestic demand: in the United States, sourcing from Japan declined (from 12\% to 5\%) while the share from China increased from $18 \%$ to $28 \%$. For the European Union, a similar pattern of reallocation prevailed. Japan's domestic share declined from $10 \%$ to $5 \%$ and most of this change was offset by an increased dependence on Chinese sources. The rest of the world saw a pattern of declining dependence on the European Union, the United States and Japan and a significant increase in sourcing from China (from $12 \%$ to $29 \%$ ).

\section{Regional demand for information industries products , 2005 and 2015 by country or region of value added origin, percentage shares of total}

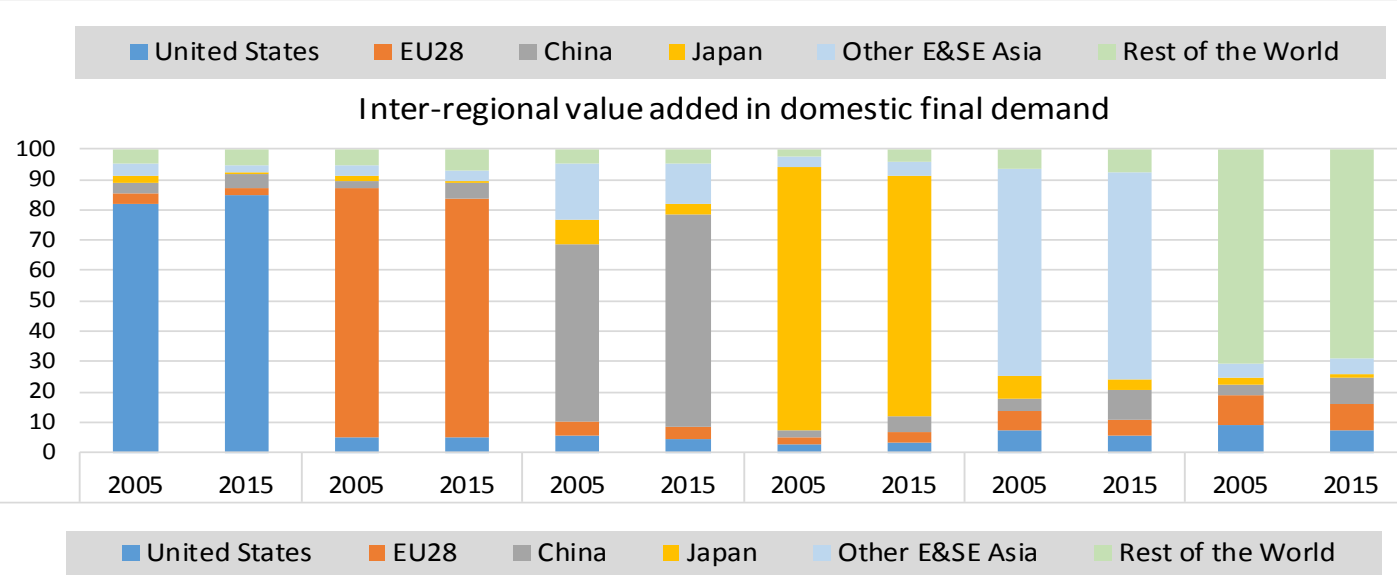

Inter-regional foreign value added in domestic final demand

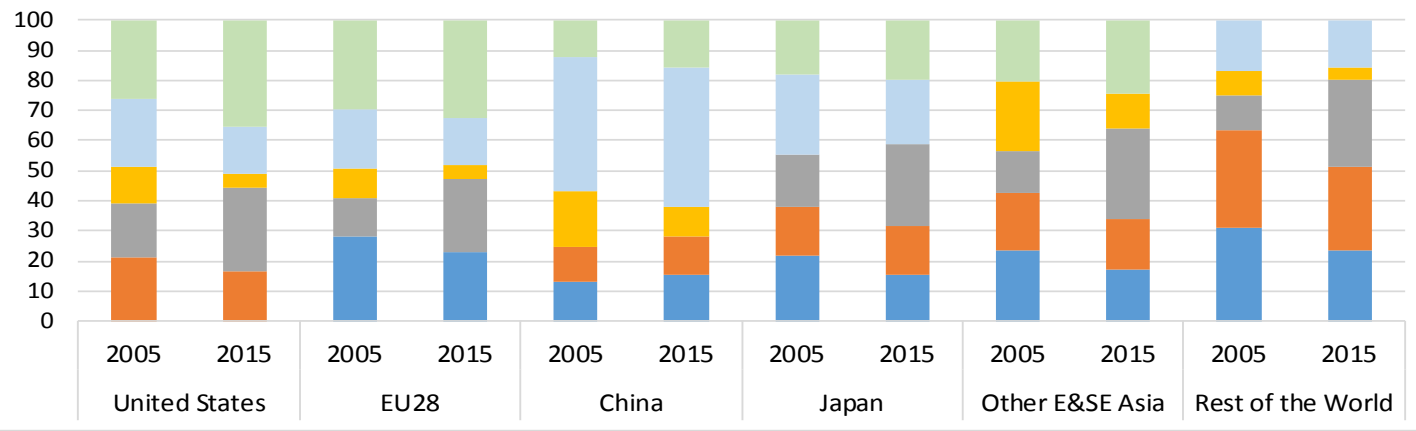

Source: Estimation based on OECD's Inter-Country Input-Output Database, 2018 


\subsection{Motor vehicles}

Figure 4.12 highlights some important changes in the share of North America in final demand, in this case increasing from $32 \%$ to $35 \%$ while Europe's share declined $(33 \%$ to $18 \%$ ) as did Japan's, registering a decline from $8 \%$ to $3 \%$ much of which was accounted for by China's increasing share (6\% to $21 \%)$. In value added terms, North America increased by just around 2 percentage point while Japan declined by almost $50 \%(14 \%$ to $7 \%$ ) with China's share following the change in demand, increasing almost four times from $6 \%$ to $24 \%$.

Figure 4.12. Global demand for Motor vehicles, by country or region of final demand and origin of value added, percentage shares of total, 2005 and 2015

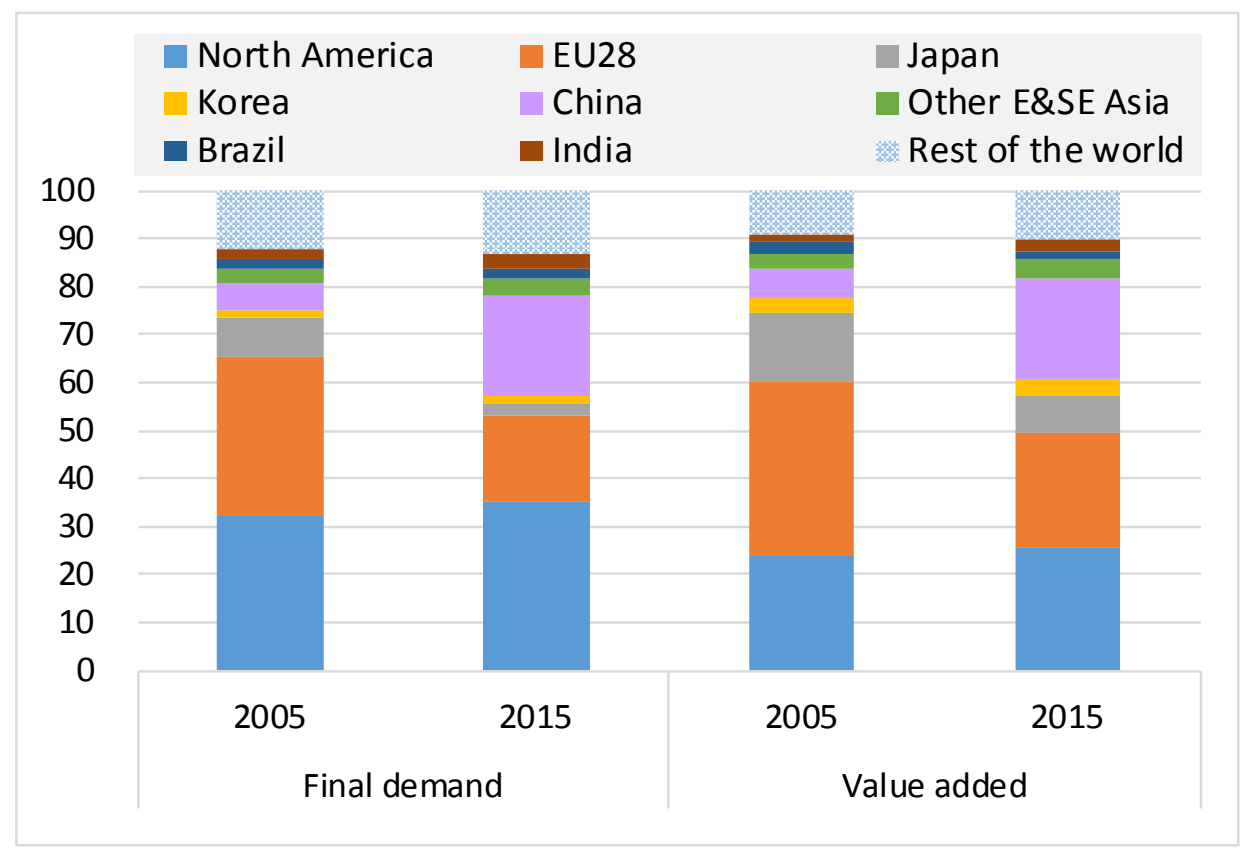

Source: OECD, Trade in Value Added database, http://oe.cd/tiva, 2018, Origin of value added in final demand. 
Figure 4.13. Regional demand for Motor vehicles by economy or region of value added origin, percentage shares of total, 2005 and 2015

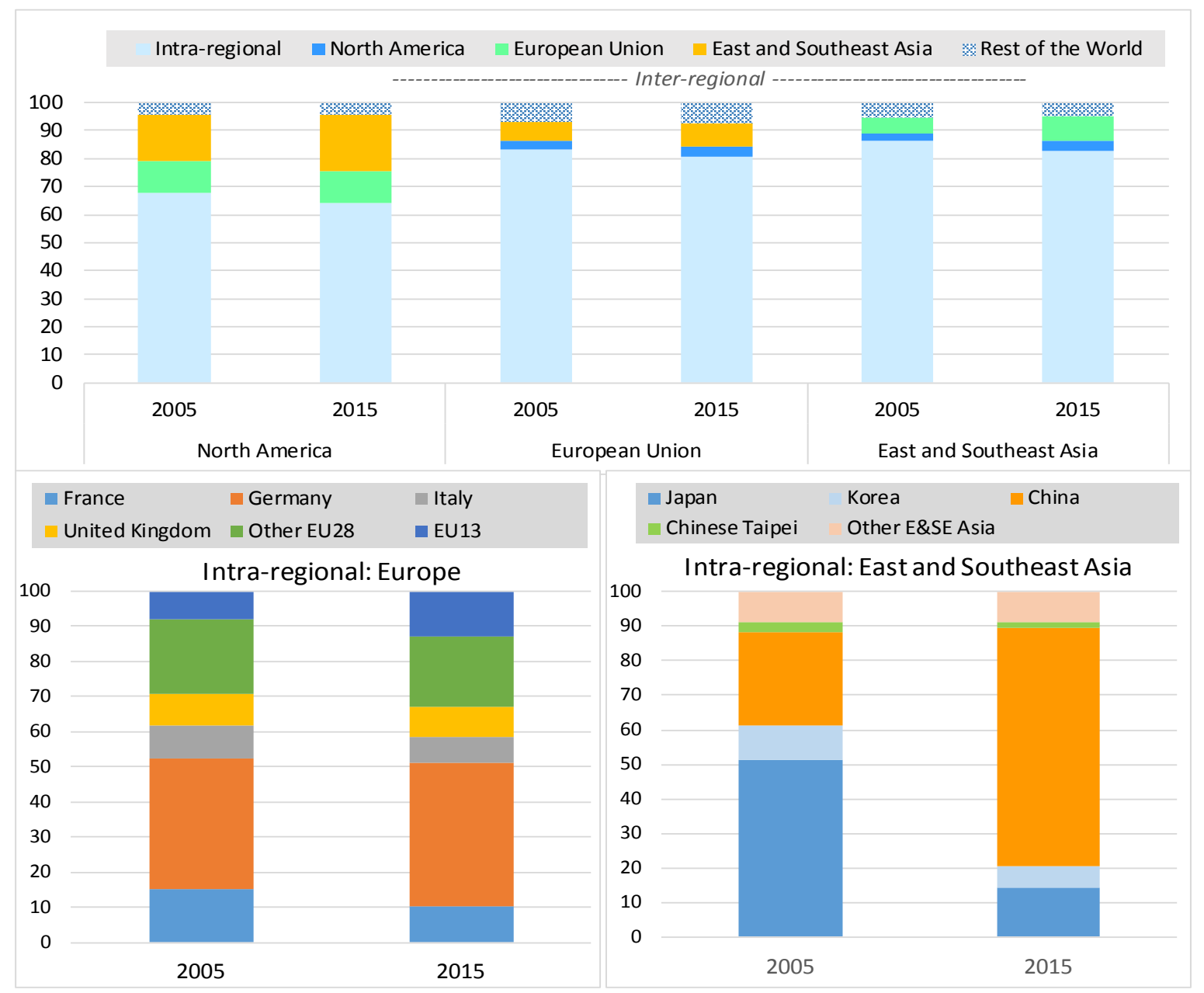

Source: OECD, Trade in Value Added database, http://oe.cd/tiva, 2018, Origin of value added in final demand

The intra-regional shares of demand changed little over this period moving by between 1 and 3 percentage points (Figure 4.13 and Figure 4.14). Most of the declines in North America and Europe were matched by increases in demand from East and Southeast Asia. However, within this latter region, the changes were very significant; Japan declined from $51 \%$ to $14 \%$ while China increased from $27 \%$ to $69 \%$. Within Europe, the changes were small with Germany increasing its share while the shares of France and Italy declined. Once again, the foreign value added share in domestic final demand witnessed a combination of declines and modest increases at the individual country level. These changes were relatively modest but, for over half the countries, over $70 \%$ of value added is sourced outside the country. 
Figure 4.14. Foreign value added embodied in domestic demand for Motor vehicles, by source region, as a percentage of total domestic demand

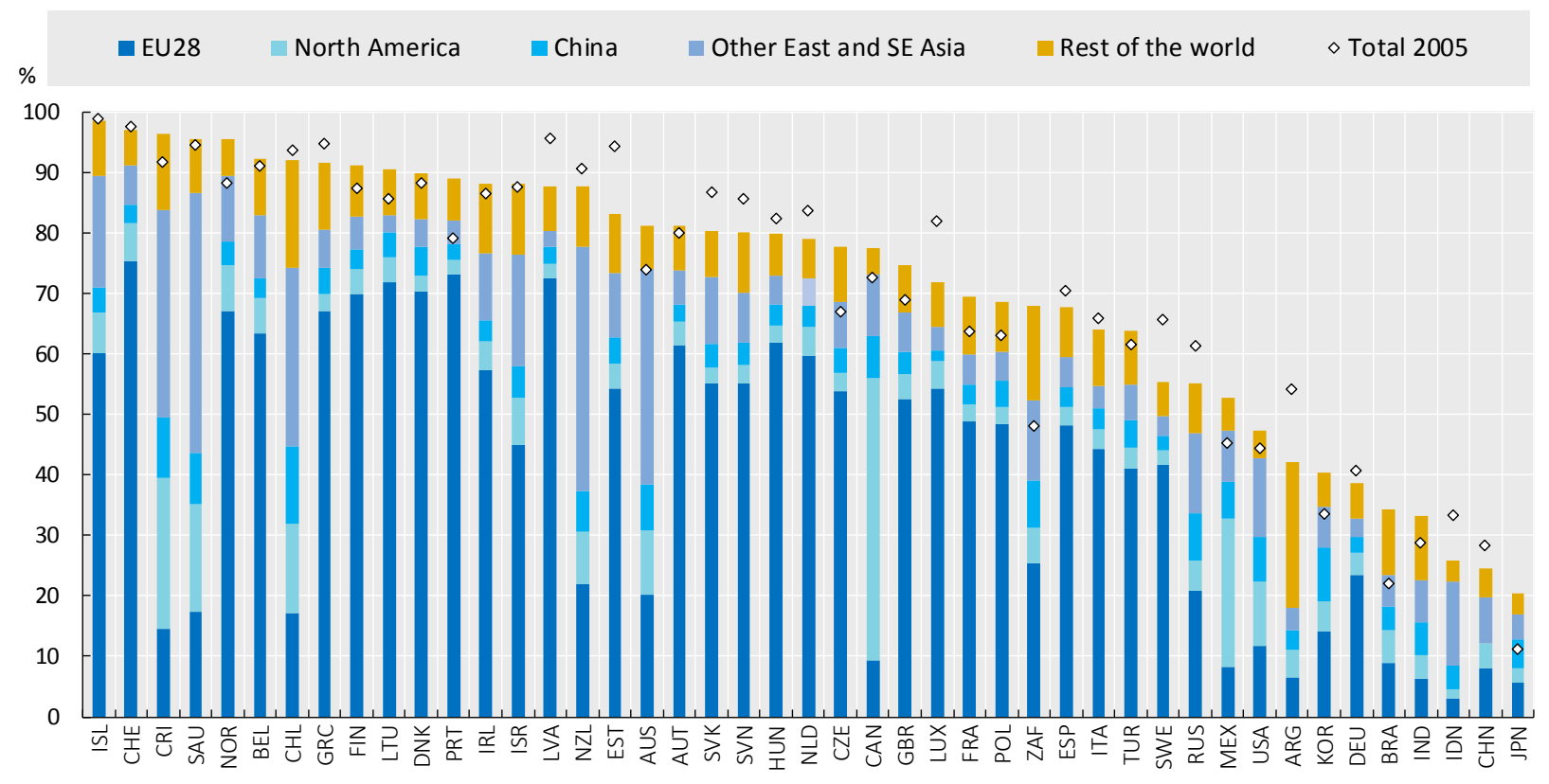

Source: Estimation based on OECD's Inter-Country Input-Output Database (2018)

In the introduction, it was noted that fragmentation has been a major characteristic of GVCs, made possible by the provision of a variety of services that has facilitated the efficient movement of components from one location to another. In the next section, attention is directed to the role of services in manufacturing exports. 


\section{Box 4.2. Origin of Value added in US imports from Mexico}

The complex manner in which global and regional integration in value chains interact can be further illustrated by analysing the domestic value added content of imports. For example, US value added embodied in US imports of "electronics, machinery and transport equipment" (ISIC Rev.4 Divisions 26 to 30) from Mexico. The share of value added directly sourced from Mexico slightly increased over the period $2005-2015$ (from $46 \%$ to $50 \%$ ). While US value added content fell ( $22 \%$ to $18 \%$ ), China's value added embodied in these US imports from Mexico increased from 5\% to $12 \%$.

US imports of electronics, machinery and transport equipment from Mexico by country or region origin of value added, 2005 to 2015, USD Billions

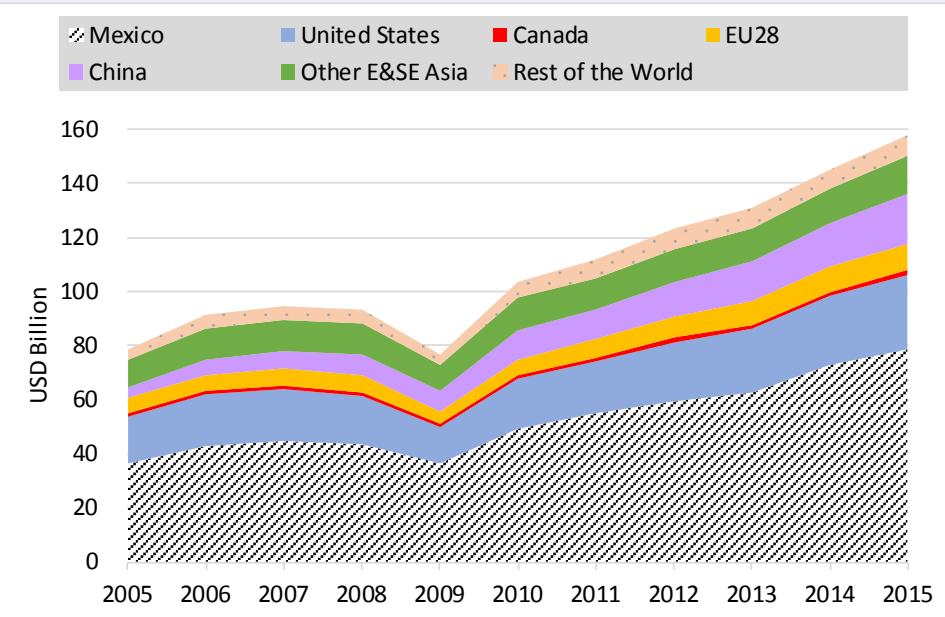

Source: OECD, Trade in Value Added database, http://oe.cd/tiva, 2018, Origin of value added in gross imports

A closer look at regions for 2015, reveals differences in the industries of origin of value added. Besides the electronic, machinery and transport equipment industries themselves, the main source of manufacturing value added was from "Chemicals, metals and other mineral products" (Divisions 19 to 25). Services accounted for $45 \%$ of US valued added embodied in US imports from Mexico.

\section{US imports of electronics, machinery and transport equipment from Mexico} by country or region and industry origin of value added, 2015, USD millions

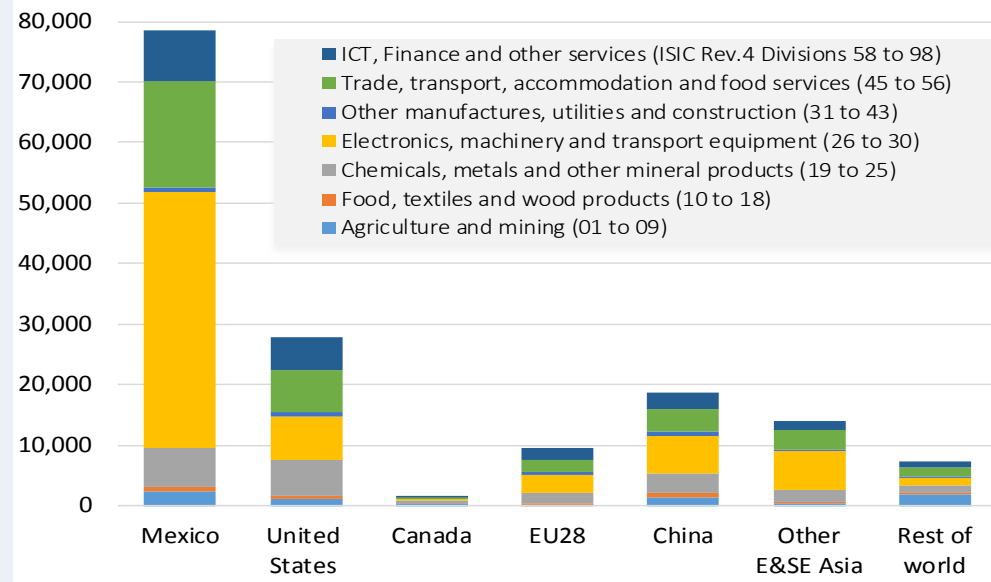

Source: OECD, Trade in Value Added database, http://oe.cd/tiva, 2018, Origin of value added in gross imports 


\section{The changing role of services}

While Johnson and Noguera (2012) used input-output tables in their analysis, they did not fully exploit the ability to explore changes in production structure, and specifically the increased role of services in the export of manufactured goods. As early as the 1980s, analysts began to notice that part of the decline in manufacturing, as measured by shares of employment or value added in the total economy, could be attributed to the outsourcing of service activities that were once included under the umbrella of manufacturing. These activities ranged from janitorial and food services to transportation services (for inputs and outputs) and a variety of business services such as legal and insurance activities.

While outsourcing of service sector functions by manufacturing firms is likely to have significant implications for "domestic" value chains, the extent to which it affects global value chains will depend upon the degree to which service sector functions can be traded internationally and hence, offshored. While many factors determine the propensity for offshoring service activities, such as technological advances (especially digitalisation), the depth and breadth of service sector trade liberalization will be important. Moreover, such opportunities are likely to vary within and across regions.

While the ICIO/TiVA database infrastructure cannot distinguish between a general propensity to outsource from the specific propensity to offshore, it is possible to cast some light on the overall effect. Figure 5.1 highlights the role of services by showing the service sector value added content of manufactured exports by origin, domestic or foreign, of the services value added. For most OECD and G20 countries, the total service value added content ranges between $25 \%$ and $40 \%$, with many experiencing an increase over the period from 2005 to 2015. There is a wide variation in the mix of domestic and foreign contributions; for Luxembourg, 43 percent points of the $55 \%$ share of services was imported in 2015, while for India, foreign services value added accounted for 7 percent points of the $23 \%$ total share. Splitting foreign services content of manufactured exports into intra-regional and extra-regional origin, reveals that in the European Union, on average, about $58 \%$ of the foreign value added is intra-regional i.e. originating from other EU countries - the share exceeding $60 \%$ for many of the smaller countries.

The significant contribution of services is partly due to their role in facilitating exporting activities - for example, the trade and transportation services required to move manufactured goods from producers to consumers abroad and, the IT, telecommunications and financial services that ensure orders are processed and paid for efficiently.

An often overlooked contribution to value added in an economy is the role of non-resident expenditure. In addition to cross-border transactions, goods and services can be exported via non-resident spending on the domestic territory e.g. due to tourism activities or the presence of foreign students. Figure 5.2 shows value added origins of non-resident household expenditure. While for many countries such spending accounts for less than 5\% of total exports, for some, such as Greece, Costa Rica, New Zealand and Turkey the share exceeds $15 \%$. Spending on final goods and services by non-residents (e.g. accommodation and food services) has a notable indirect impact on the activities of upstream suppliers (e.g. the food and agricultural sector supplying restaurants), both domestic and foreign. On average, indirect domestic value added content accounted for about a third of spending by non-resident households in 2015. Tourism is one of the fastest growing sectors worldwide and is likely to continue to have a significant impact not only in countries that have 
historically been major destinations but also to countries that are increasingly being explored by tourists who are seeking variety by finding new so-called secondary destinations.

Figure 5.1. Services value added embodied in manufactured exports, by domestic and foreign origin, 2015, as a percentage of total manufacturing exports

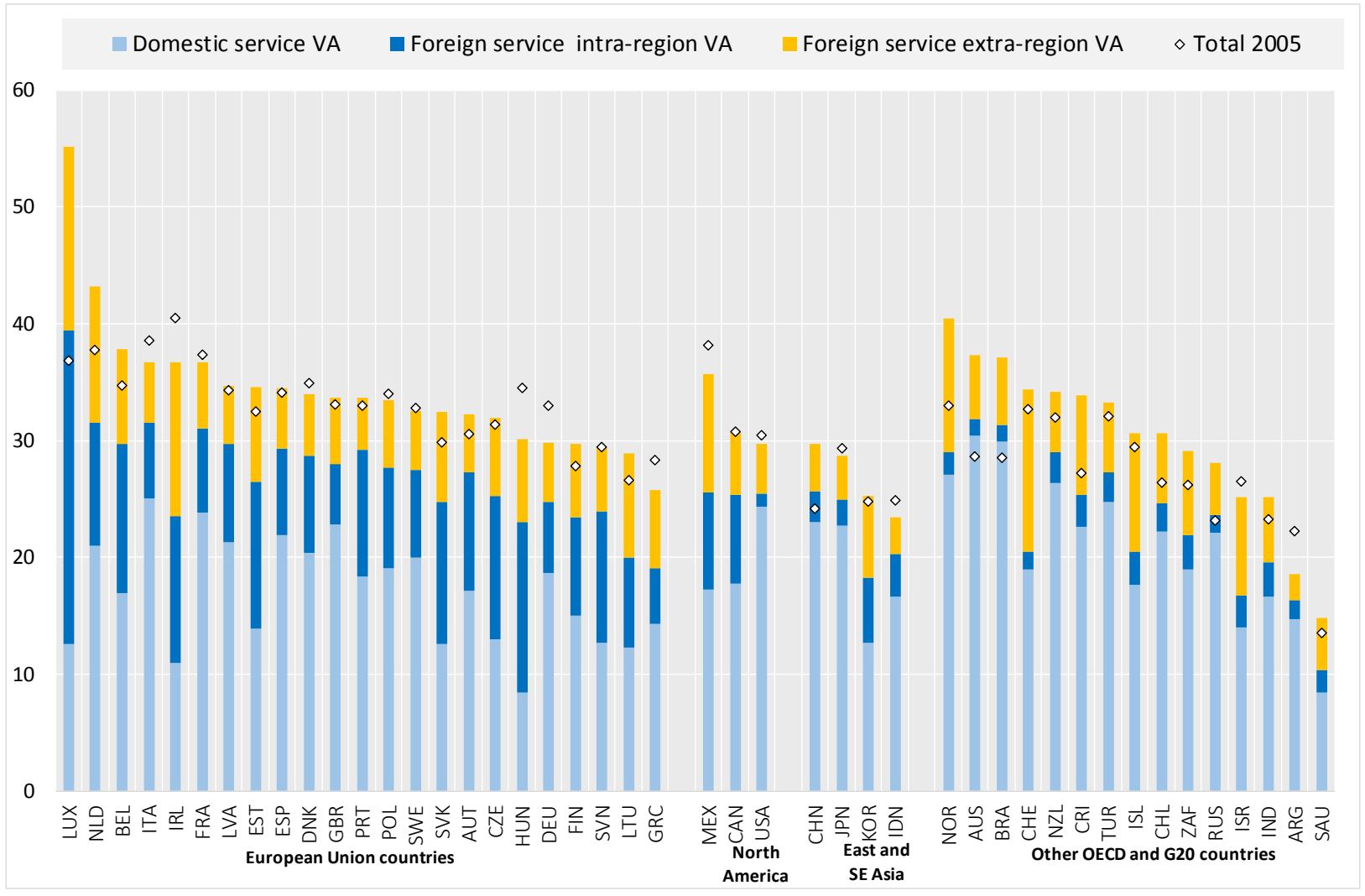

Source: OECD, Trade in Value Added database, http://oe.cd/tiva, 2018, Origin of value added in gross exports 
Figure 5.2. Non-resident households' expenditure by origin of value added, 2015 as a percentage of total gross exports

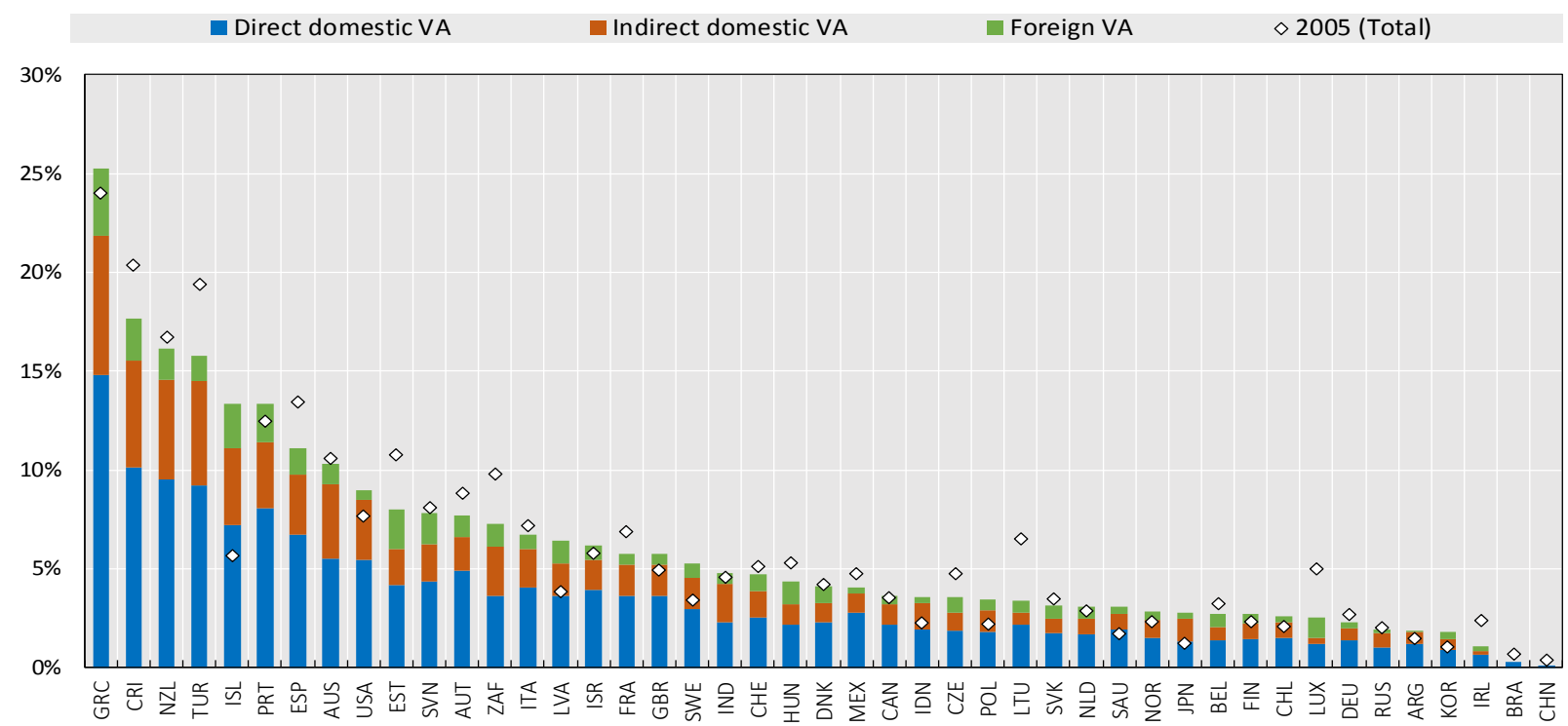

Source: Estimation based on OECD's Inter-Country Input-Output (ICIO) Database, 2018 


\section{Extensions: labour market and climate change impacts}

This section provides evidence based on analytical "extensions" using the ICIO tables. Results are presented for two important issues associated with the international fragmentation of production - labour market impacts and carbon emission impacts. In the former case, attention focuses on skilled labour, with the recognition that the mix of skills within a workforce plays an important role in affecting the distribution of income within a country - and between countries. The second issue, $\mathrm{CO}_{2}$ emissions, has been an increasing source of concern, with debate about the most appropriate way to measure the emissions by location of production or by location of consumption - in order to better grasp trends in emissions and the implications of policy settings.

\subsection{Labour market impacts}

As noted in De Backer and Flaig (2017), many stages of production in different manufacturing industries have been relocated to emerging economies as sourcing inputs from producers in countries with lower real wages has lowered production costs. Moreover, with many economies facing the prospect of declining workforces, the opportunities for emerging economies to capture increasing shares of the GVCs would seem to increasing. As a result of the higher population growth in emerging economies in East and Southeast Asia and Africa, over 1 billion additional persons are projected to be of working age over the coming years (OECD, 2016). With increased fragmentation of production processes, countries in these regions can specialise in very specific production activities rather than seeking to develop activities across the whole value chain.

Using the OECD Trade in Employment (TiM) database ${ }^{14}$, Figure 6.1 and Figure 6.2 presents jobs and labour compensation in the business sector sustained by foreign demand, disaggregated by region of demand. On average in OECD countries, there has been an increase over time but there are some important variations by country with Chile and China decreasing their external dependence while for most European Union (EU28) countries and the United States, the dependence increased, although not dramatically (1-3 percentage points in most cases). A similar pattern may be found in Figure 6.2 when the data are presented in terms of labour compensation.

Many countries that have already been actively participating in GVCs are increasingly looking to "upgrade" their GVC activities to higher value added stages of production. However, contrast the findings reported in section 4; this has been the case for China in motor vehicles but not for Mexico. In the former case, there has been a clear substitution of domestic intermediate inputs for imported ones. In Mexico's case, the intermediates are primarily imported. The final impact on value added will be very different. Further, the skill requirements are likely to be different and hence the returns to labour will be much higher in China's case (even after adjusting for purchasing power parity differences).

There is a rich literature on the implications for workers with different skills, with Feenstra and Hanson $(1996,1999)$ providing some of the first robust evidence that the rise of outsourcing accounted for a significant part of the increase in the relative demand for skilled labour in US manufacturing industries in the 1980s. Geishecker (2006) undertook a similar study for Germany and found that the growth of international outsourcing in the 1990s partly explained the decline in demand for manual workers in manufacturing. More recently there has been a rich vein of work looking at the implications for workers engaged 
in tasks that are susceptible to automation (see Marcolin et al. 2016 and Grundke et al. 2017). These issues form the basis for increasing attention on the income inequality implications for increasing fragmentation; in many developed economies over the last two decades, the elimination of manufacturing jobs has eliminated opportunities for many manual workers. However, demand for highly skilled manufacturing workers remains high, thus setting in motion the dynamics of increasing income inequality.

While again, for the OECD as a whole, there was an increase, many countries such as China, Brazil and Argentina experienced a decrease. Figure 6.3 delves further into the labour contribution by focusing on high-skilled employment ${ }^{15}$ in manufacturing. Increasingly, new developments in manufacturing (such as 3-D technology) have changed the skill-requirements for workers; in some cases, this has been accompanied by re-shoring of an activity away from cheaper labour sources abroad back to higher labour cost locations that are nearer to the sources of demand. (See De Backer and Flaig 2017 and De Backer et al. 2018). The improvements in efficiency, the decreases in transportation and coordination costs often overcome higher labour costs. This will be a focus for change over the next decade; in some countries, concerns are emerging about the mismatch of skills, with labour shortages, resulting from the absence of appropriate training programmes, limiting the uptake of some advanced manufacturing technologies.

Looking more closely at the case of skills composition, Figure 6.3 presents data for highskilled employment as a percentage of total manufacturing employment, with respect to both domestic final demand and foreign final demand. It is interesting to note that for some relatively large European economies (e.g. Germany, France, Italy, Sweden, and Netherlands) foreign final demand is more important than domestic final demand in supporting high-skilled employment. Much of this is, of course, attributable to intraregional fragmentation.

Figure 6.1. Jobs in the business sector sustained by foreign demand, by region of demand, 2015, as a percentage of total business sector employment

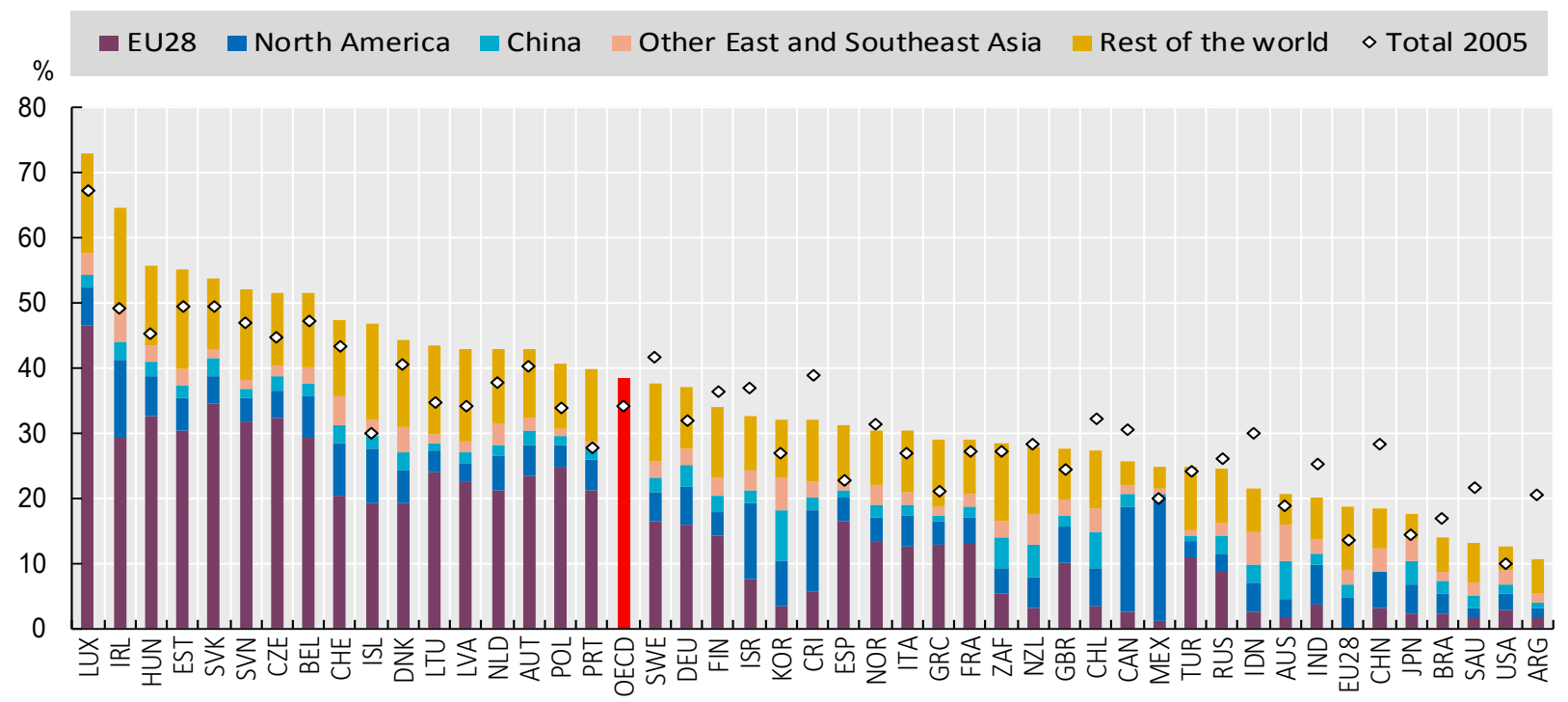

Source: OECD, Trade in Employment database, http://oe.cd/io-emp, 2019 
Figure 6.2. Labour compensation of employees in business sector embodied in foreign demand, by region of demand, 2015, as a percentage of total business sector labour compensation of employees

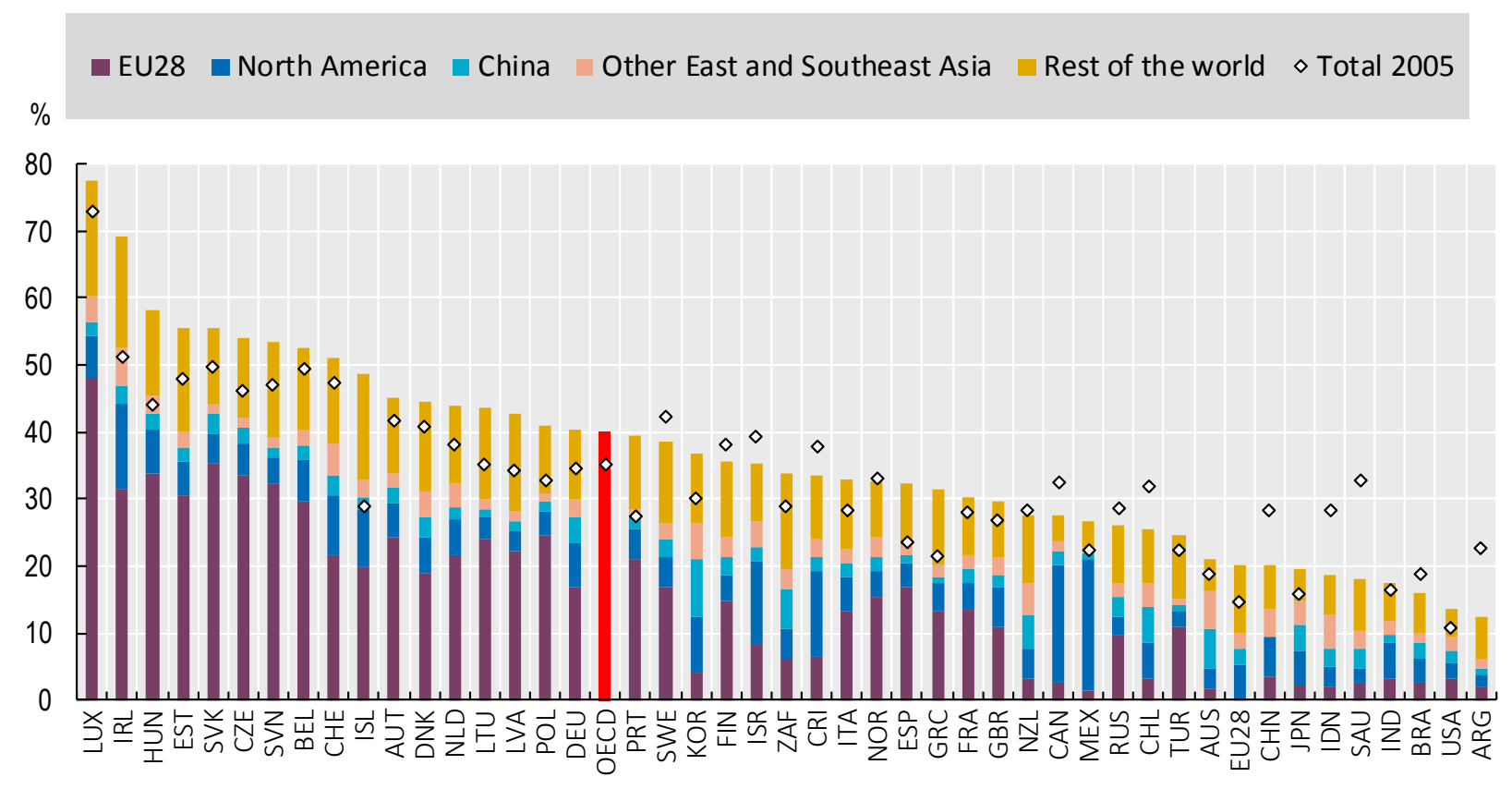

Source: OECD, Trade in Employment database, http://oe.cd/io-emp, 2019

Figure 6.3. High-skilled employment in manufacturing meeting domestic and foreign demand, 2015, as a percentage of total manufacturing employment

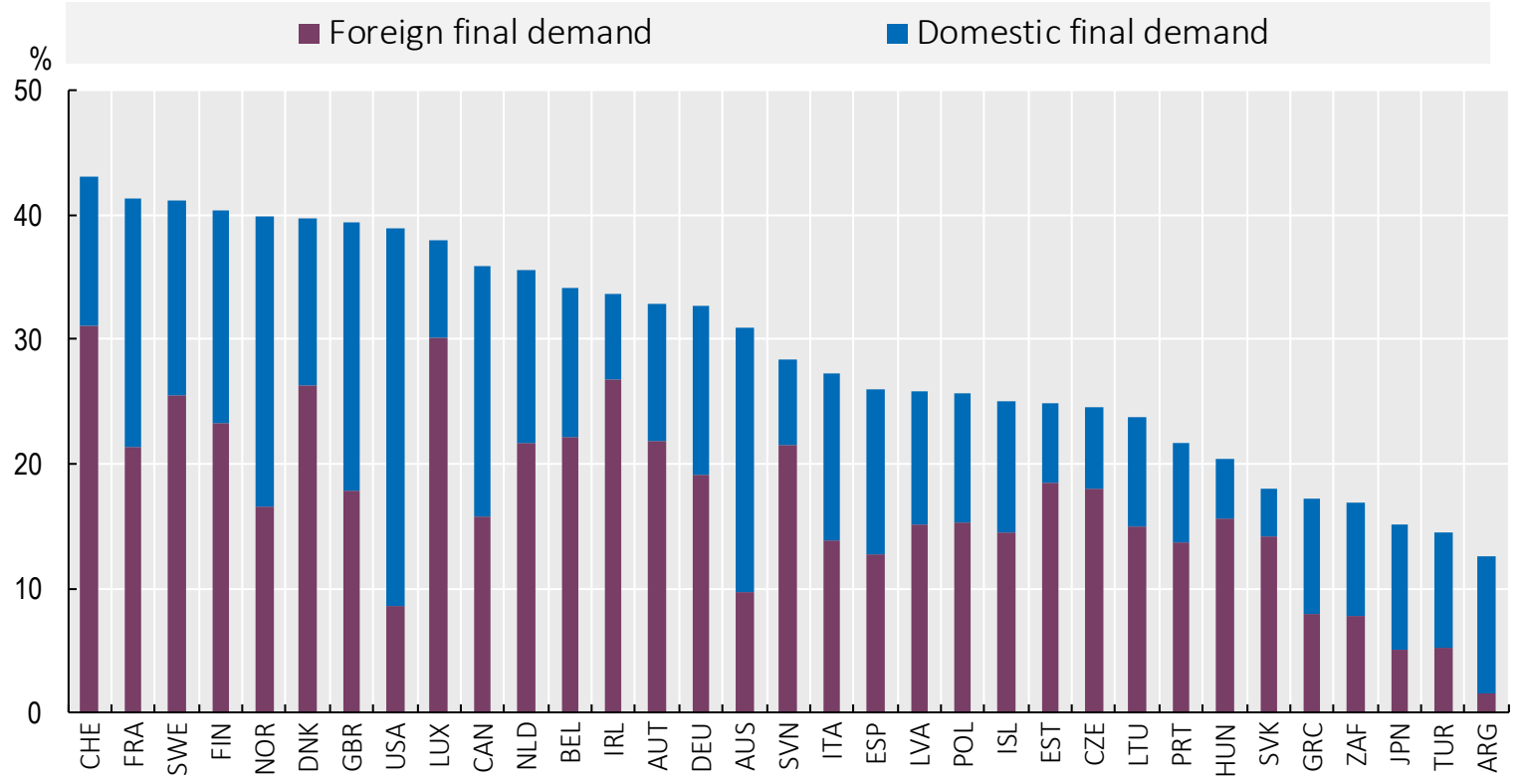

Source: Estimation based on OECD's Inter-Country Input-Output and STAN Databases, 2018 


\subsection{Climate change impacts}

How do changes in the international fragmentation of production affect the volume and spatial pattern of greenhouse gas (GHG) emissions? The OECD has been addressing these issues for some time: see, for example, Wiebe and Yamano (2016) and Yamano and Guilhoto (2019) for a discussion on carbon dioxide $\left(\mathrm{CO}_{2}\right)$ emissions using estimates based on ICIO tables. Drawing on the 2018 update, Figure 6.4 compares aggregate OECD and aggregate non-OECD production-based emissions, where $\mathrm{CO}_{2}$ is allocated to the location in which the goods or services are produced; and, consumption-based emissions i.e. where $\mathrm{CO}_{2}$ is allocated to the locations in which consumption occurs. Net imports of $\mathrm{CO}_{2}$ emissions from fuel combustion by OECD countries from non-OECD countries are estimated to have fallen from 2.1 to 1.6 Gigatonnes (Gt) between 2005 and 20

Figure 6.4. $\mathrm{CO}_{2}$ emissions from fuel combustion (OECD and non-OECD countries), consumption-based and production-based $\left(\mathrm{Gt} \mathrm{CO}_{2}\right)$

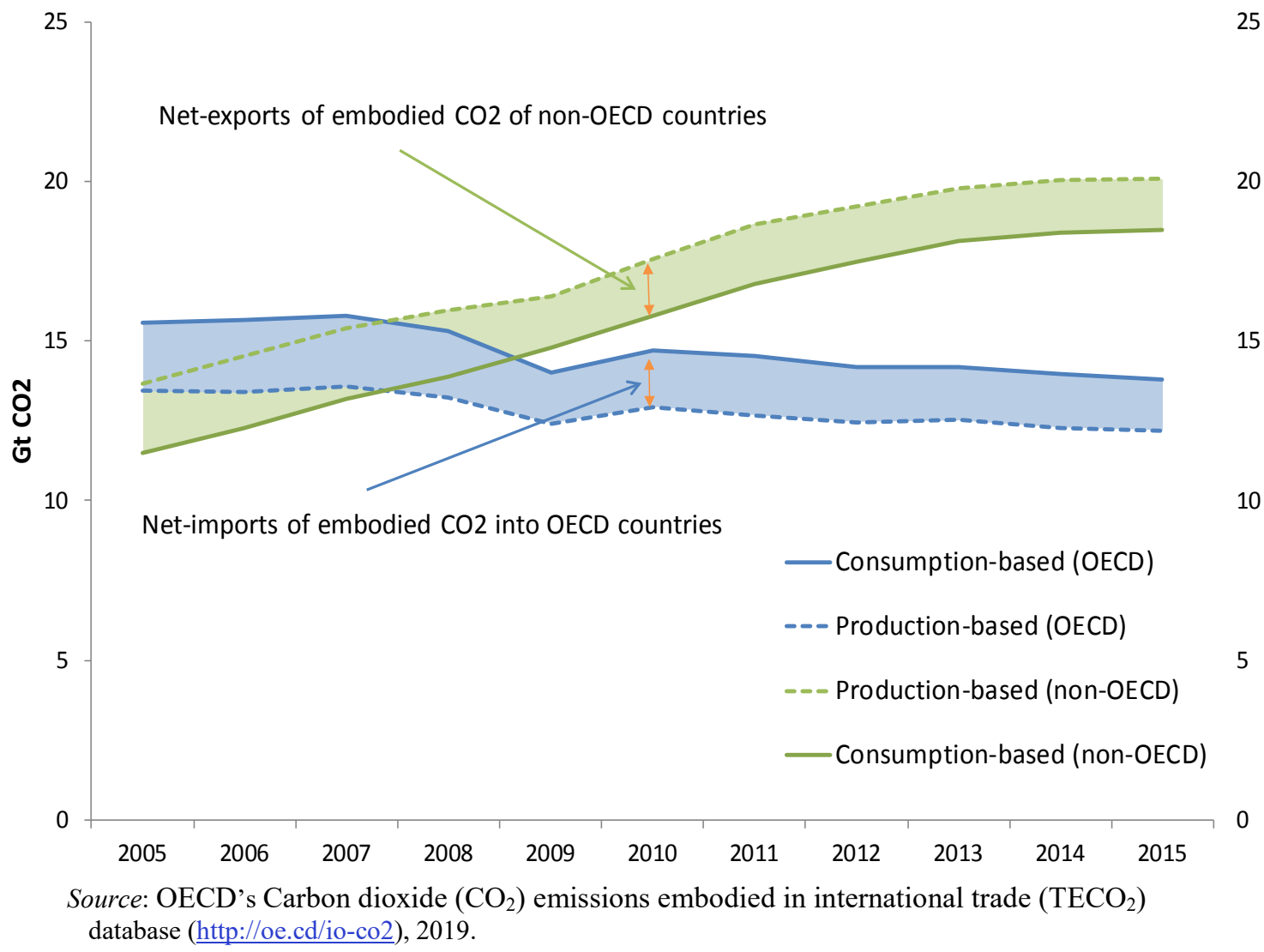

Figure 6.5 examines production-based and consumption-based $\mathrm{CO}_{2}$ emissions per capita, based on fuel combustion. One encouraging feature of this chart is the decline over the period 2005-2015.

Figure 6.6 complementing Figure 6.4, presents the share of $\mathrm{CO} 2$ emitted abroad, sourced from OECD and non-OECD regions, embodied in final demand. The data reveal that the overall decline in the imports of $\mathrm{CO} 2$ did not happen in a uniform way; some countries, intentionally or not, are still following a strategy that outsources emissions. 
The distinction between production-based and consumption-based emissions is directly relevant for on-going policy discussions. Recognizing that developed countries were principally responsible for the high levels of GHGs in the atmosphere at the time of signing of the Kyoto Protocol in 1997, the Protocol placed a heavier burden on developed nations under the principle of "common but differentiated responsibilities." (see Rose, 1998 and Ringius et al., 2002). ${ }^{16}$ This language has spawned a lively debate about what constitutes a "fair" allocation of rights to emit GHGs and the burden associated with its mitigation, and such debates have informed subsequent negotiations at meetings of the Conference of the Parties (COPs).

Even if consumption-based emissions accounting is not considered to be appropriate for the allocation of rights and burdens, it can be helpful to better understand the forces that are driving trends and patterns in global emission levels. Indeed, a comparison of disaggregated production-based and consumption-based measures of emissions is arguably the most appropriate means to assess the importance of carbon leakage in a world of heterogeneous climate policy settings. Countries with ambitious climate mitigation targets may achieve decoupling of production-based emissions from economic growth by offshoring domestic production abroad, with some of the emissions coming home through the "back door" in the form of carbon-intensive imports (Weber and Peters, 2009).

Figure 6.5. Per capita $\mathrm{CO}_{2}$ emissions from fuel combustion, consumption-based and productionbased (tonnes $\mathrm{CO}_{2}$ )

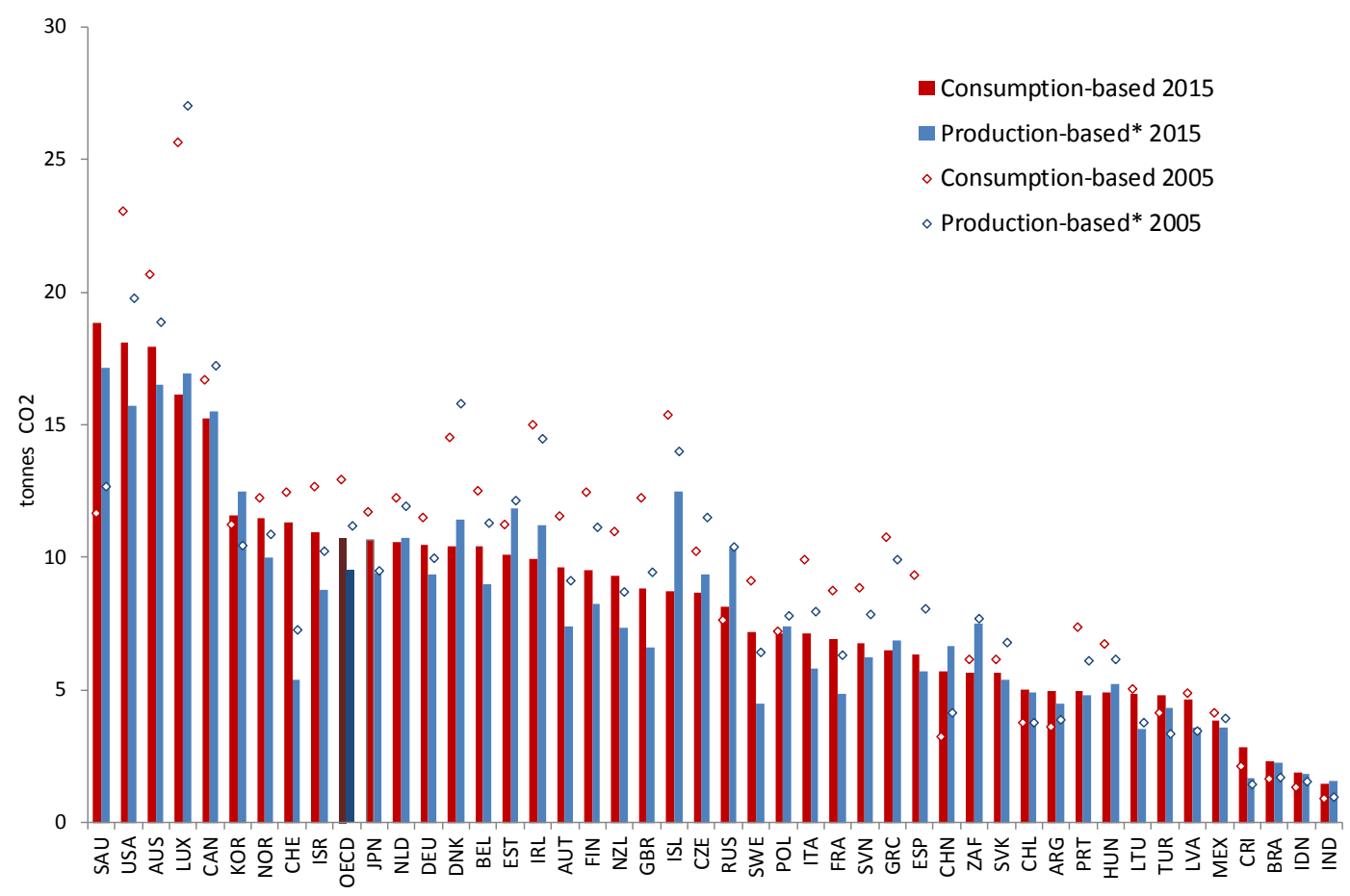

Source: OECD's Carbon dioxide $\left(\mathrm{CO}_{2}\right)$ emissions embodied in international trade $\left(\mathrm{TECO}_{2}\right)$ database (http://oe.cd/io-co2), 2019 
Figure 6.6. Share of $\mathrm{CO}_{2}$ emitted abroad in total $\mathrm{CO}_{2}$ embodied in domestic final demand

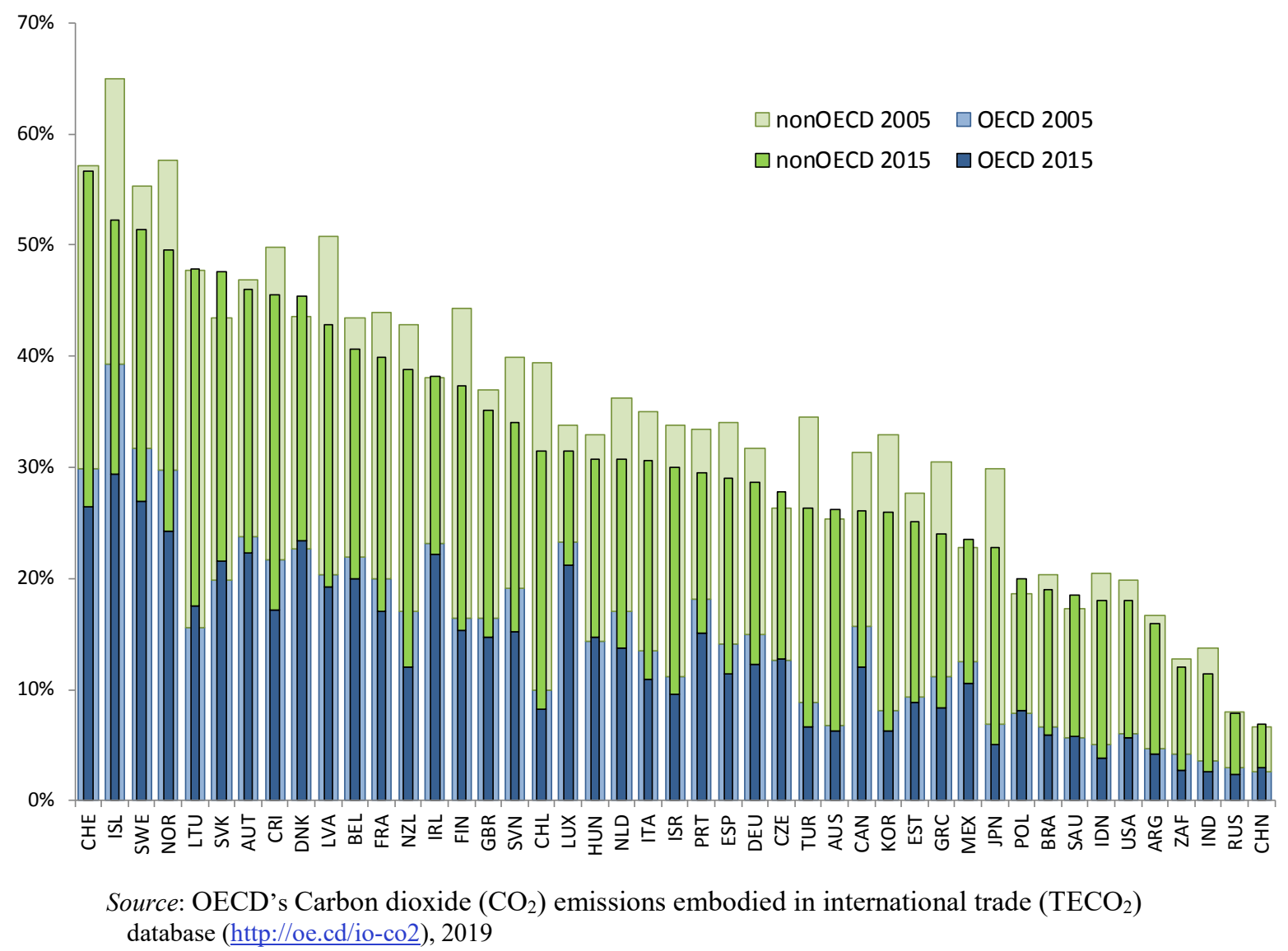

OECD SCIENCE, TECHNOLOGY AND INDUSTRY WORKING PAPERS 


\section{Concluding remarks}

Drawing upon the 2018 update of the OECD ICIO/TiVA database, this paper highlight results from 2005 to 2015, a period during in which a major global recession occurred. As some of the changes may reflect a "hangover" from this massive downturn, a more detailed analysis, using this database, can untangle the changes due to the downturn itself and from those associated with structural change such as changing competitive advantage, changes in firm ownership and changes in the location of final expenditures.

In addition, recent trade disputes have created some uncertainty about the stability of global patterns of trade. The prospect of the United Kingdom leaving the European Union may induce further destabilisation and highlights an important issue that has further affected the international structure of production after the period analysed here. Moreover, the analysis presented in this report focuses at the level of the nation-state; however, the sub-national economies of many of these countries are very heterogeneous.

Recent analysis of the regional impacts of Brexit on the local economies of the United Kingdom (Dhingra, et al., 2017) and on the regional economies of the European Union (Chen et al., 2017) highlight this important heterogeneity. For example, Chen et al. (2017) showed that the impacts on the regions of Spain and Portugal would be very small; in contrast, the forecasts were for significant impacts on many regions in Germany and significant variation across the regions of the United Kingdom. Earlier work by Haddad and Hewings (2005) found that reduction in external tariffs in Brazil had a positive impact on almost all sectors in the more prosperous centre-south regions of the country and a decidedly negative impact on sectors in the Northeast of the country. Dietzenbacher, Guilhoto and Imori (2013) by developing a methodology to combining subnational models with a global input-output models have analysed the role played by Brazilian regions in the global value chain (GVC). Yamano (2017) has developed a methodology to link the OECD Inter-Country Input-Output database with subnational input-output tables to enable analysis of the sub-national impacts of changes in fragmentation, globalisation and so forth.

The OECD ICIO/TiVA database provides a rich data infrastructure to analyse these and other policy-relevant questions. For example, uncertainties in the political sphere about the benefits from enhanced global trade and multilateral trade agreements are likely to generate changes that could be assessed. Similarly, the effects of unexpected events (such as earthquakes or floods) on global value chains could be analysed. In addition, the links between trade, investment and innovation could be further analysed, with a specific focus on the role of multi-national enterprises and other types of firms. Issues related to employment market impacts and $\mathrm{CO}_{2}$ emissions have also been raised in this report, but examination of the links with policy settings are clearly areas in which further analysis is warranted. 


\section{End Notes}

1 TiVA indicators are provided for 64 economies (plus an aggregate "Rest of World") and, 36 unique industries and related industry aggregates, see Annex A, OECD (2018a), OECD (2018b), and Guilhoto et al. (2019).

2 These manufacturing sectors are defined according to ISIC Revision 4. Divisions 13 to 15: Textiles and apparel; Divisions 20 and 21: Chemical and pharmaceutical products; Division 26: Computer, electronic and optical products; and, Division 29: Motor vehicles

${ }^{3}$ See OECD's Trade in Employment (TiM) database (http://oe.cd/io-emp) and OECD's Carbon dioxide $\left(\mathrm{CO}_{2}\right)$ emissions embodied in international trade $\left(\mathrm{TECO}_{2}\right)$ database (http://oe.cd/io-co2).

${ }^{4}$ See Jones and Kierzkowski (2005) for a discussion of the "international fragmentation perspective". Also, Fujita and Thisse (2006) who presented these developments in the context of the New Economic Geography paradigm.

${ }^{5}$ Discussion of how the choice of methodologies and world input-output databases can have an impact in the results and analysis of globalisation can be found in the papers by Koopman et al. (2014), Owen et al. (2016), Lenaerts and Merlevede (2016), Reich (2018), and Los et al. (2016).

${ }^{6}$ See http://oe.cd/icio, http://oe.cd/tiva, Guilhoto et al. (2019).

${ }^{7}$ For further details see www.oecd.org/industry/ind/tiva-2018-differences-tiva-2016.pdf.

${ }^{8}$ North America comprises Canada, USA, and Mexico.

${ }^{9}$ East and Southeast Asia includes Brunei Darussalam, Cambodia, China, Hong Kong (China), Indonesia, Japan, Korea, Malaysia, Philippines, Singapore, Thailand, Chinese Taipei and Viet Nam.

${ }^{10}$ Additional work in estimating the value added embodied in trade can also be found in Reimer, (2006), Stehrer (2012), Koopman et al. (2012, 2014), and Los et al. (2015, 2016).

${ }^{11}$ Manufactures are defined as ISIC Rev.4 Divisions 10 to 33, while Business services cover Divisions 45 to 82.

12 EU13 refers to the countries who joined the European Union on or after $1^{\text {st }}$ May 2004: Bulgaria, Croatia, Cyprus*, Czech Republic, Estonia, Hungary, Latvia, Lithuania, Malta, Poland, Romania, Slovakia and Slovenia.

*Note by Turkey: The information in this document with reference to "Cyprus" relates to the southern part of the Island. There is no single authority representing both Turkish and Greek Cypriot people on the Island. Turkey recognises the Turkish Republic of Northern Cyprus (TRNC). Until a lasting and equitable solution is found within the context of the United Nations, Turkey shall preserve its position concerning the "Cyprus issue".

Note by all the European Union Member States of the OECD and the European Union: The Republic of Cyprus is recognised by all members of the United Nations with the exception of Turkey. The information in this document relates to the area under the effective control of the Government of the Republic of Cyprus.

${ }^{13}$ For example, advances in biotechnology, nanotechnology, digital technology (blockchains, 3D printing etc.) and their related $\mathrm{R} \& \mathrm{D}$, innovation and patenting activities and, increased international supply of high technology intermediate products.

${ }^{14}$ See http://oe.cd/io-emp, Horvát et al. (2019).

15 The definition of high-skilled employment used here is based on occupations and refers to major groups 1 to 3 of the International Standard Classification of Occupations, 2008 (ISCO-08).

${ }^{16}$ Article 3.1 of the UNFCCC (1992) "the Parties should protect the climate system for the benefit of present and future generations of humankind, on the basis of equity and in accordance with their common but differentiated responsibilities and respective capabilities." Article 3.2 distinguishes between developed and developing countries, and states that full consideration "should be given to the specific needs and circumstances" of developing countries:

https://unfccc.int/resource/docs/convkp/conveng.pdf 


\section{References}

Chen, W., B Los, P. McCann, R. Ortega-Argilés, M.Thissen, and F. van Oort (2017) "The continental divide? Economic exposure to Brexit in regions and countries on both sides of The Channel", Papers in Regional Science, June 2017, DOI: 10.1111/pirs.12334.

De Backer, K. and D. Flaig (2017) "The future of global value chains: Business as usual or "a new normal"?", OECD Science, Technology and Industry Policy Papers, No. 41, OECD Publishing, Paris, https://doi.org/10.1787/d8da8760-en.

De Backer, K., T. DeStefano, C. Menon, and J.R. Suh (2018) "Industrial robotics and the global organisation of production", OECD Science, Technology and Industry Working Papers, No. 2018/03, OECD Publishing, Paris, https://doi.org/10.1787/dd98ff58-en.

Dhingra, S., S. Machin and H. Overman (2017) "Local economic effects of Brexit”, National Institute Economic Review, 242, 24-36

Dietzenbacher, E., J.J.M. Guilhoto, D. Imori (2013). : The Role of Brazilian Regions in the Global Value Chain". In: 21st International Input-Output Conference, 2013, Kitakyushu. 21 st International InputOutput Conference.

Fujita, M. and J-F. Thisse (2006) "Globalisation and the evolution of the supply chain: who gains and who loses?”, International Economic Review, 47, 811-836.

Feenstra, Robert C. and Gordon H. Hanson. (1996) "Foreign Investment, Outsourcing and Relative Wages," in R.C. Feenstra, G.M. Grossman and D.A. Irwin, eds., The Political Economy of Trade Policy: Papers in Honor of Jagdish Bhagwati, MIT Press, 89-127.

Feenstra, Robert C. and Gordon H. Hanson (1999) "Productivity Measurement and the Impact of Trade and Technology on Wages: Estimates for the U.S., 1972-1990," Quarterly Journal of Economics, August, 114(3), 907-940.

Geishecker, I. (2006), "Does Outsourcing to Central and Eastern Europe Really Threaten Manual Workers' Jobs in Germany?", The World Economy, 29(5), 559-583.

Grundke, R., S. Jamet, M. Kalamova, M. Squicciarini (2017) "Having the right mix: The role of skill bundles for comparative advantage and industry performance in GVCs", OECD Science, Technology and Industry Working Papers, No. 2017/03, OECD Publishing, Paris, https://doi.org/10.1787/892a4787-en.

Guilhoto, J.J.M., C. Webb, and N. Yamano (2019) “Guide to OECD's TiVA Indicators, 2018 Edition”, OECD Science, Technology and Industry Working Papers. Forthcoming.

Haddad, E. and G.J.D. Hewings, (2005) "Market imperfections in a spatial economy: some experimental results", The Quarterly Review of Economics and Finance 45, 476-496

Horvát, P., C. Webb and N. Yamano (2019). "Measuring Employment in Global Value Chains", OECD Science, Technology and Industry Working Papers. Forthcoming.

IEA (2018) “ $\mathrm{CO}_{2}$ emissions from fuel consumption”, International Energy Agency, Paris: https://www.iea.org/statistics/co2emissions/ 
Johnson, R.C. and G. Noguera (2012) "Proximity and Production Fragmentation", American Economic Review, 102, 407-411.

Johnson, R.C. and G. Noguera (2017) "A Portrait of Trade in Value-Added over Four Decades", The Review of Economics and Statistics, 99, 896-911.

Jones, R.W. and H. Kierzkowski (2005) "International fragmentation and the new economic geography", North American Journal of Economics and Finance, 16, 1-10

Koopman R., Z. Wang and S. Wei (2012) "Estimating Domestic Content in Exports When Processing Trade is Pervasive", Journal of Development Economics, 99, 178-189.

Koopman R., Z. Wang, and S. Wei (2014) "Tracing Value-added and Double Counting in Gross Exports", American Economic Review, 104, 459-494.

Lenaerts, K. and B. Merlevede (2016) "Supply chain fragmentation, input-output tables and spillovers from foreign direct investment", Economic Systems Research, 28, 315-332.

Los, B., M. Timmer and G. de Vries (2016) "Tracing Value-Added and Double Counting in Gross Exports: Comment", American Economic Review, 106, 1958-1966.

Los, B., M. Timmer and G. de Vries (2015) "How Global are Global Value Chains? A New Approach to Measure International Fragmentation”, Journal of Regional Science, 55, 66-92.

Marcolin, L. and M. Squicciarini (2017) "Investing in innovation and skills: Thriving in global value chains", OECD Science, Technology and Industry Policy Papers, No. 44, OECD Publishing, Paris,https://doi.org/10.1787/9e296b43-en.

Marcolin, L., S. Miroudot and M. Squicciarini (2016) "GVCs, Jobs and Routine Content of Occupations", OECD Trade Policy Papers, No. 187, OECD Publishing, Paris, https://doi.org/10.1787/5jm0mq7kr6s8-en.

OECD (2013) Interconnected Economies: Benefiting from Global Value Chains, OECD Publishing, Paris, https://doi.org/10.1787/9789264189560-en.

OECD (2016b), “OECD Science, Technology and Innovation Outlook”, OECD Publishing, Paris, http://dx.doi.org/10.1787/sti in outlook-2016-en

OECD (2018a) Inter-Country Input-Output Database, http://oe.cd/icio/

OECD (2018b) Trade in Value Added, http://oe.cd/tiva/

Owen, A., R. Wood, J. Barrett and A. Evans (2016) "Explaining value chain differences in MRIO databases through structural path decomposition", Economic Systems Research, 28, 243-272

Reich, U-P. (2018) "Accounting for international trade in value added: a comment on the OECD-WTO project”, Economic Systems Research, 30, 462-477

Reimer, J. (2006) "Global production sharing and trade in the services of factors", Journal of International Economics, 68, 384-408.

Ringius, L., A. Torvanger and A. Underdal (2002) "International Environmental Agreements: Politics", Law and Economics 2: 1. https://doi.org/10.1023/A:1015041613785

Rose, A. (1998) "Burden-sharing and climate change policy beyond Kyoto: Implications for developing countries", Environment and Development Economics, 3(3), 347-409.

Stehrer, R. (2012) "Trade in Value Added and the Valued Added in Trade", WIIW Working Paper No.81, Vienna. 
Weber, C. and G. Peters (2009) "Climate change policy and international trade: Policy considerations in the US", Energy Policy, Volume 37, Issue 2, 432-440. https://doi.org/10.1016/j.enpol.2008.09.073

Wiebe, K. and N. Yamano (2016) "Estimating CO2 Emissions Embodied in Final Demand and Trade Using the OECD ICIO 2015: Methodology and Results", OECD Science, Technology and Industry Working Papers, No. 2016/05, OECD Publishing, Paris, https://doi.org/10.1787/5jlrcm216xk1-en.

Yamano, N. (2017) "Development of regional extended Inter-country Input-Output Database", Chapter 3 of Development of Global Inter-Country Inter-Industry Systems for Various Policy Perspectives, unpublished doctoral dissertation, Urbana, Illinois, University of Illinois.

Yamano, N. and J.J.M. Guilhoto (2019). "CO2 Emissions Embodied in International Trade and Final Demand, Using the OECD ICIO 2018". OECD Science, Technology and Industry Working Papers. Forthcoming. 


\section{Annex A. TiVA 2018 geographical coverage}

\section{TiVA 2018 Country List}

\begin{tabular}{|c|c|c|c|c|c|}
\hline N. & Code & Country & N. & Code & Country \\
\hline 1 & AUS & Australia & 37 & ARG & Argentina \\
\hline 2 & AUT & Austria & 38 & BRA & Brazil \\
\hline 3 & BEL & Belgium & 39 & BRN & Brunei Darussalam \\
\hline 4 & CAN & Canada & 40 & BGR & Bulgaria \\
\hline 5 & $\mathrm{CHL}$ & Chile & 41 & KHM & Cambodia \\
\hline 6 & CZE & Czech Republic & 42 & $\mathrm{CHN}$ & China (People's Republic of) \\
\hline 7 & DNK & Denmark & 43 & $\mathrm{COL}$ & Colombia \\
\hline 8 & EST & Estonia & 44 & CRI & Costa Rica \\
\hline 9 & FIN & Finland & 45 & HRV & Croatia \\
\hline 10 & FRA & France & 46 & CYP & Cyprus \\
\hline 11 & DEU & Germany & 47 & IND & India \\
\hline 12 & GRC & Greece & 48 & IDN & Indonesia \\
\hline 13 & HUN & Hungary & 49 & HKG & Hong Kong, China \\
\hline 14 & ISL & Iceland & 50 & $\mathrm{KAZ}$ & Kazakhstan \\
\hline 15 & IRL & Ireland & 51 & MYS & Malaysia \\
\hline 16 & ISR & Israel & 52 & MLT & Malta \\
\hline 17 & ITA & Italy & 53 & MAR & Morocco \\
\hline 18 & JPN & Japan & 54 & PER & Peru \\
\hline 19 & KOR & Korea & 55 & $\mathrm{PHL}$ & Philippines \\
\hline 20 & LVA & Latvia & 56 & ROU & Romania \\
\hline 21 & LTU & Lithuania & 57 & RUS & Russian Federation \\
\hline 22 & LUX & Luxembourg & 58 & SAU & Saudi Arabia \\
\hline 23 & MEX & Mexico & 59 & SGP & Singapore \\
\hline 24 & NLD & Netherlands & 60 & ZAF & South Africa \\
\hline 25 & NZL & New Zealand & 61 & TWN & Chinese Taipei \\
\hline 26 & NOR & Norway & 62 & THA & Thailand \\
\hline 27 & $\mathrm{POL}$ & Poland & 63 & TUN & Tunisia \\
\hline 28 & PRT & Portugal & 64 & VNM & Viet Nam \\
\hline 29 & SVK & Slovak Republic & 65 & ROW & Rest of the World \\
\hline 30 & SVN & Slovenia & & & \\
\hline 31 & ESP & Spain & & & \\
\hline 32 & SWE & Sweden & & & \\
\hline 33 & $\mathrm{CHE}$ & Switzerland & & & \\
\hline 34 & TUR & Turkey & & & \\
\hline 35 & GBR & United Kingdom & & & \\
\hline 36 & USA & United States & & & \\
\hline
\end{tabular}

Note by Turkey: The information in this document with reference to "Cyprus" relates to the southern part of the Island. There is no single authority representing both Turkish and Greek Cypriot people on the Island. Turkey recognises the Turkish Republic of Northern Cyprus (TRNC). Until a lasting and equitable solution is found within the context of the United Nations, Turkey shall preserve its position concerning the "Cyprus issue". Note by all the European Union Member States of the OECD and the European Union: The Republic of Cyprus is recognised by all members of the United Nations with the exception of Turkey. The information in this document relates to the area under the effective control of the Government of the Republic of Cyprus.

Note: Countries 1 to 36, in blue, are OECD member countries 
TiVA 2018 Regions List

\begin{tabular}{|c|c|c|c|}
\hline N. & Region & Heading & Countries \\
\hline 1 & OECD & OECD member countries & Countries 01 to 36 \\
\hline 2 & NONOECD & $\begin{array}{l}\text { Non-OECD economies and } \\
\text { aggregates }\end{array}$ & Countries 37 to 65 \\
\hline 3 & APEC & $\begin{array}{l}\text { Asia-Pacific Economic } \\
\text { Cooperation }^{1}\end{array}$ & $\begin{array}{l}\text { AUS, CAN, CHL, JPN, KOR, MEX, NZL, USA, BRN, } \\
\text { CHN, HKG, IDN, MYS, PER, PHL, RUS, SGP, THA, } \\
\text { TWN, VNM }\end{array}$ \\
\hline 4 & ASEAN & $\begin{array}{l}\text { Association of South East Asian } \\
\text { Nations }^{2}\end{array}$ & BRN, IDN, KHM, MYS, PHL, SGP, THA, VNM \\
\hline 5 & EASIA & Eastern Asia & JPN, KOR, CHN, HKG, TWN \\
\hline 6 & EU28 & European Union (28 countries) & $\begin{array}{l}\text { AUT, BEL, CZE, DNK, EST, FIN, FRA, DEU, GRC, HUN, } \\
\text { IRL, ITA, LVA, LTU, LUX, NLD, POL, PRT, SVK, SVN, } \\
\text { ESP, SWE, GBR, BGR, CYP, HRV, MLT, ROU }\end{array}$ \\
\hline 7 & EU15 & European Union (15 countries) & $\begin{array}{l}\text { AUT, BEL, DNK, FIN, FRA, DEU, GRC, IRL, ITA, LUX, } \\
\text { NLD, PRT, ESP, SWE, GBR }\end{array}$ \\
\hline 8 & EU13 & EU28 excluding EU15 & $\begin{array}{l}\text { CZE, EST, HUN, LVA, LTU, POL, SVK, SVN, BGR, CYP, } \\
\text { HRV, MLT, ROU }\end{array}$ \\
\hline 9 & EA19 & Euro area (19 countries) & $\begin{array}{l}\text { AUT, BEL, EST, FIN, FRA, DEU, GRC, IRL, ITA, LVA, } \\
\text { LTU, LUX, NLD, PRT, SVK, SVN, ESP, CYP, MLT }\end{array}$ \\
\hline 10 & EA12 & Euro area (12 countries) & $\begin{array}{l}\text { AUT, BEL, FIN, FRA, DEU, GRC, IRL, ITA, LUX, NLD, } \\
\text { PRT, ESP }\end{array}$ \\
\hline 11 & G20 & Group of Twenty & $\begin{array}{l}\text { AUS, CAN, JPN, KOR, MEX, TUR, USA, ARG, BRA, } \\
\text { CHN, IND, IDN, RUS, SAU, ZAF, EU28 }\end{array}$ \\
\hline \multicolumn{4}{|c|}{ World divided into regions } \\
\hline N. & Region & Heading & Countries \\
\hline 12 & ZEUR & Europe & $\begin{array}{l}\text { AUT, BEL, CZE, DNK, EST, FIN, FRA, DEU, GRC, HUN, } \\
\text { ISL, IRL, ITA, LVA, LTU, LUX, NLD, NOR, POL, PRT, } \\
\text { SVK, SVN, ESP, SWE, CHE, GBR, BGR, CYP, HRV, } \\
\text { MLT, ROU, RUS }\end{array}$ \\
\hline 13 & ZASI & East and South East Asia & $\begin{array}{l}\text { JPN, KOR, BRN, CHN, HKG, IDN, KHM, MYS, PHL, } \\
\text { SGP, THA, TWN, VNM }\end{array}$ \\
\hline 14 & ZNAM & $\begin{array}{l}\text { North American Free Trade } \\
\text { Association }\end{array}$ & CAN, MEX, USA \\
\hline 15 & ZOTH & Other regions & $\begin{array}{l}\text { AUS, ISR, NZL, TUR, IND, KAZ, MAR, SAU, TUN, ZAF, } \\
\text { ROW }\end{array}$ \\
\hline 16 & ZSCA & South and Central America & CHL, ARG, BRA, COL, CRI, PER \\
\hline 17 & WLD & World & \\
\hline 18 & $\mathrm{DXD}$ & Domestic & Dummy partner used in the diagonal for some indicators. \\
\hline
\end{tabular}

Note by Turkey: The information in this document with reference to "Cyprus" relates to the southern part of the Island. There is no single authority representing both Turkish and Greek Cypriot people on the Island. Turkey recognises the Turkish Republic of Northern Cyprus (TRNC). Until a lasting and equitable solution is found within the context of the United Nations, Turkey shall preserve its position concerning the "Cyprus issue".

Note by all the European Union Member States of the OECD and the European Union: The Republic of Cyprus is recognised by all members of the United Nations with the exception of Turkey. The information in this document relates to the area under the effective control of the Government of the Republic of Cyprus.

Notes: OECD member countries are in blue; 1. APEC country not included in 2018 TiVA database: Papua New Guinea; 2. ASEAN countries not included in 2018 TiVA database: Lao PDR and Myanmar. 


\section{Annex B. Expanded data used in charts}

Table B.1. Foreign value added shares of total exports, $2010=1.00$, by region (Figure 2.1)

\begin{tabular}{cccccccc}
\hline Year & OECD & EU28 & EU4 & G20 & $\begin{array}{c}\text { E\&SE } \\
\text { Asia }\end{array}$ & N.Am & $\begin{array}{c}\text { S\&C } \\
\text { Am }\end{array}$ \\
\hline 2010 & 1.00 & 1.00 & 1.00 & 1.00 & 1.00 & 1.00 & 1.00 \\
2011 & 1.16 & 1.09 & 1.08 & 1.11 & 1.11 & 1.08 & 1.03 \\
2012 & 1.17 & 1.12 & 1.08 & 1.13 & 1.10 & 1.09 & 1.09 \\
2013 & 1.12 & 1.06 & 1.03 & 1.09 & 1.08 & 1.02 & 1.13 \\
2014 & 1.06 & 1.01 & 0.98 & 1.02 & 1.03 & 0.98 & 1.17 \\
2015 & 0.95 & 0.97 & 0.93 & 0.88 & 0.85 & 0.93 & 1.20 \\
\hline
\end{tabular}

Source: OECD, Trade in Value Added (TiVA) database, http://oe.cd/tiva, 2018.

Table B.2. Foreign value added shares of total exports for selected countries, $2010=$ 1.00 (Figure 2.2)

\begin{tabular}{cccccccccc}
\hline Year & FRA & DEU & KOR & TUR & GBR & USA & CHN & IND & IDN \\
\hline 2010 & 1.00 & 1.00 & 1.00 & 1.00 & 1.00 & 1.00 & 1.00 & 1.00 & 1.00 \\
2011 & 1.06 & 1.08 & 1.11 & 1.13 & 1.08 & 1.15 & 1.03 & 1.06 & 1.03 \\
2012 & 1.05 & 1.07 & 1.10 & 1.19 & 1.08 & 1.12 & 0.99 & 1.06 & 1.07 \\
2013 & 1.03 & 1.04 & 1.03 & 1.11 & 1.03 & 1.04 & 0.97 & 1.05 & 1.12 \\
2014 & 1.01 & 1.01 & 0.98 & 1.06 & 0.93 & 1.01 & 0.93 & 0.97 & 1.13 \\
2015 & 0.97 & 0.98 & 0.85 & 0.98 & 0.86 & 0.86 & 0.82 & 0.81 & 1.04 \\
& & & & & & & & RUS & ZAF \\
\hline Year & AUS & CAN & IRL & JPN & MEX & NOR & BRA & RUS \\
\hline 2010 & 1.00 & 1.00 & 1.00 & 1.00 & 1.00 & 1.00 & 1.00 & 1.00 & 1.00 \\
2011 & 1.07 & 1.01 & 0.99 & 1.18 & 0.95 & 0.91 & 1.01 & 0.97 & 1.11 \\
2012 & 1.09 & 1.05 & 1.05 & 1.15 & 1.00 & 0.87 & 1.11 & 0.90 & 1.22 \\
2013 & 1.04 & 1.00 & 1.06 & 1.25 & 1.02 & 0.90 & 1.18 & 0.92 & 1.30 \\
2014 & 1.10 & 0.97 & 1.10 & 1.30 & 1.01 & 1.00 & 1.20 & 0.97 & 1.30 \\
2015 & 1.13 & 1.02 & 0.99 & 1.09 & 1.06 & 1.13 & 1.30 & 1.11 & 1.21 \\
\hline
\end{tabular}

Source: OECD, Trade in Value Added (TiVA) database, http://oe.cd/tiva, 2018. 
Table B.3. Foreign value added share of total gross exports, as a percentage of total gross exports (Figure 2.3)

\begin{tabular}{|c|c|c|c|c|c|c|c|}
\hline Country & 2005 & 2010 & 2015 & Country & 2005 & 2010 & 2015 \\
\hline AUS & 11.1 & 10.3 & 11.6 & ARG & 11.0 & 10.6 & 6.9 \\
\hline AUT & 25.5 & 28.0 & 26.5 & BRA & 11.2 & 9.6 & 12.5 \\
\hline BEL & 30.6 & 33.5 & 34.1 & BRN & 7.5 & 7.5 & 5.4 \\
\hline CAN & 19.6 & 20.7 & 21.2 & BGR & 32.4 & 34.1 & 36.2 \\
\hline $\mathrm{CHL}$ & 17.7 & 13.8 & 15.1 & KHM & 29.5 & 26.6 & 26.9 \\
\hline CZE & 34.4 & 37.2 & 39.3 & $\mathrm{CHN}$ & 26.3 & 21.1 & 17.3 \\
\hline DNK & 26.2 & 28.0 & 29.3 & COL & 10.5 & 8.0 & 11.6 \\
\hline EST & 30.4 & 33.9 & 34.8 & CRI & 22.9 & 19.1 & 16.2 \\
\hline FIN & 27.5 & 29.4 & 25.9 & HRV & 22.3 & 20.7 & 20.0 \\
\hline FRA & 20.4 & 22.1 & 21.4 & CYP & 23.6 & 25.4 & 27.8 \\
\hline DEU & 18.6 & 21.5 & 21.0 & IND & 18.8 & 23.6 & 19.1 \\
\hline GRC & 19.1 & 23.0 & 24.5 & IDN & 18.4 & 12.5 & 12.9 \\
\hline HUN & 44.0 & 47.5 & 43.1 & HKG & 27.7 & 31.6 & 26.6 \\
\hline ISL & 23.4 & 24.7 & 23.7 & KAZ & 20.3 & 9.6 & 6.5 \\
\hline IRL & 35.7 & 40.7 & 40.2 & MYS & 45.0 & 40.6 & 36.9 \\
\hline ISR & 25.3 & 22.3 & 18.6 & MLT & 50.9 & 64.3 & 59.1 \\
\hline ITA & 20.5 & 24.0 & 22.2 & MAR & 22.7 & 23.0 & 25.7 \\
\hline JPN & 10.2 & 12.2 & 13.2 & PER & 13.3 & 12.3 & 10.3 \\
\hline KOR & 32.7 & 38.2 & 32.6 & PHL & 26.3 & 23.9 & 22.0 \\
\hline LVA & 21.4 & 21.8 & 22.4 & ROU & 27.6 & 21.1 & 22.9 \\
\hline LTU & 29.5 & 32.8 & 31.6 & RUS & 9.9 & 9.7 & 10.8 \\
\hline LUX & 58.2 & 60.4 & 68.8 & SAU & 4.1 & 3.3 & 4.6 \\
\hline MEX & 34.0 & 33.9 & 36.1 & SGP & 42.8 & 41.3 & 40.9 \\
\hline NLD & 22.9 & 23.6 & 27.9 & ZAF & 17.8 & 18.7 & 22.6 \\
\hline NZL & 14.9 & 14.9 & 13.8 & TWN & 37.1 & 41.5 & 32.4 \\
\hline NOR & 11.8 & 12.3 & 13.9 & THA & 38.4 & 36.0 & 33.6 \\
\hline POL & 24.7 & 26.9 & 26.6 & TUN & 25.4 & 26.6 & 28.5 \\
\hline PRT & 26.4 & 26.9 & 28.4 & VNM & 36.1 & 40.5 & 44.5 \\
\hline SVK & 43.0 & 43.9 & 44.8 & ROW & 13.4 & 11.8 & 12.0 \\
\hline SVN & 33.3 & 33.9 & 32.5 & & & & \\
\hline ESP & 23.0 & 21.9 & 22.7 & & & & \\
\hline SWE & 24.6 & 24.3 & 20.7 & & & & \\
\hline $\mathrm{CHE}$ & 25.8 & 25.9 & 24.6 & & & & \\
\hline TUR & 15.4 & 17.2 & 16.8 & & & & \\
\hline GBR & 14.3 & 17.5 & 15.1 & & & & \\
\hline USA & 10.8 & 11.1 & 9.5 & & & & \\
\hline
\end{tabular}

Note by Turkey: The information in this document with reference to "Cyprus" relates to the southern part of the Island. There is no single authority representing both Turkish and Greek Cypriot people on the Island. Turkey recognises the Turkish Republic of Northern Cyprus (TRNC). Until a lasting and equitable solution is found within the context of the United Nations, Turkey shall preserve its position concerning the "Cyprus issue".

Note by all the European Union Member States of the OECD and the European Union: The Republic of Cyprus is recognised by all members of the United Nations with the exception of Turkey. The information in this document relates to the area under the effective control of the Government of the Republic of Cyprus.

Source: OECD, Trade in Value Added (TiVA) database, http://oe.cd/tiva, 2018. 
Table B.4. Foreign value added share of manufactured exports, as a percentage of total manufactured exports (Figure 2.4)

\begin{tabular}{|c|c|c|c|c|c|c|c|}
\hline Country & 2005 & 2010 & 2015 & Country & 2005 & 2010 & 2015 \\
\hline AUS & 14.3 & 14.9 & 16.9 & ARG & 14.3 & 14.1 & 9.0 \\
\hline AUT & 33.8 & 36.9 & 34.7 & BRA & 13.7 & 13.1 & 16.2 \\
\hline BEL & 39.7 & 44.5 & 44.5 & BRN & 25.1 & 17.1 & 20.6 \\
\hline CAN & 29.4 & 33.5 & 33.3 & BGR & 45.5 & 45.1 & 48.4 \\
\hline $\mathrm{CHL}$ & 24.9 & 21.9 & 20.8 & KHM & 39.7 & 33.7 & 34.9 \\
\hline CZE & 40.6 & 44.0 & 46.0 & $\mathrm{CHN}$ & 28.4 & 22.6 & 18.7 \\
\hline DNK & 28.0 & 28.8 & 26.1 & $\mathrm{COL}$ & 17.1 & 15.0 & 22.3 \\
\hline EST & 39.1 & 44.6 & 45.6 & CRI & 32.1 & 28.4 & 25.9 \\
\hline FIN & 32.1 & 35.0 & 31.4 & HRV & 31.6 & 30.4 & 29.4 \\
\hline FRA & 27.4 & 30.5 & 29.6 & CYP & 30.5 & 35.0 & 31.9 \\
\hline DEU & 22.7 & 26.0 & 25.2 & IND & 25.2 & 33.5 & 27.3 \\
\hline GRC & 31.1 & 37.6 & 40.0 & IDN & 24.6 & 18.3 & 17.6 \\
\hline HUN & 52.3 & 57.9 & 51.3 & HKG & 35.5 & 42.4 & 47.7 \\
\hline ISL & 22.3 & 24.8 & 26.6 & KAZ & 20.3 & 10.8 & 7.8 \\
\hline IRL & 38.6 & 41.5 & 33.1 & MYS & 54.2 & 49.7 & 44.6 \\
\hline ISR & 33.8 & 30.0 & 26.8 & MLT & 61.0 & 60.9 & 54.3 \\
\hline ITA & 26.2 & 30.4 & 28.2 & MAR & 31.8 & 31.6 & 33.7 \\
\hline JPN & 12.1 & 14.5 & 16.0 & PER & 17.1 & 18.9 & 15.0 \\
\hline KOR & 35.5 & 40.8 & 35.5 & PHL & 32.8 & 31.1 & 30.7 \\
\hline LVA & 28.4 & 28.5 & 29.7 & ROU & 33.7 & 23.2 & 29.8 \\
\hline LTU & 40.9 & 45.3 & 42.9 & RUS & 14.1 & 13.7 & 14.1 \\
\hline LUX & 46.9 & 54.6 & 53.8 & SAU & 12.9 & 12.3 & 13.3 \\
\hline MEX & 49.7 & 47.7 & 46.9 & SGP & 51.0 & 49.6 & 50.0 \\
\hline NLD & 31.8 & 34.9 & 40.6 & ZAF & 22.2 & 23.9 & 29.9 \\
\hline NZL & 17.6 & 18.0 & 17.4 & TWN & 42.7 & 47.3 & 37.6 \\
\hline NOR & 28.0 & 28.8 & 27.4 & THA & 44.3 & 42.1 & 40.4 \\
\hline POL & 32.0 & 35.2 & 34.3 & TUN & 31.9 & 35.3 & 33.5 \\
\hline PRT & 35.1 & 36.3 & 38.4 & VNM & 41.8 & 45.5 & 48.2 \\
\hline SVK & 51.7 & 52.1 & 52.4 & ROW & 22.6 & 20.7 & 20.1 \\
\hline SVN & 40.6 & 41.6 & 39.3 & & & & \\
\hline ESP & 32.1 & 31.5 & 32.0 & & & & \\
\hline SWE & 30.2 & 30.4 & 27.7 & & & & \\
\hline $\mathrm{CHE}$ & 33.5 & 34.4 & 32.2 & & & & \\
\hline TUR & 21.4 & 23.4 & 22.4 & & & & \\
\hline GBR & 23.9 & 29.5 & 25.1 & & & & \\
\hline USA & 16.5 & 17.7 & 15.6 & & & & \\
\hline
\end{tabular}

Note by Turkey: The information in this document with reference to "Cyprus" relates to the southern part of the Island. There is no single authority representing both Turkish and Greek Cypriot people on the Island. Turkey recognises the Turkish Republic of Northern Cyprus (TRNC). Until a lasting and equitable solution is found within the context of the United Nations, Turkey shall preserve its position concerning the "Cyprus issue". Note by all the European Union Member States of the OECD and the European Union: The Republic of Cyprus is recognised by all members of the United Nations with the exception of Turkey. The information in this document relates to the area under the effective control of the Government of the Republic of Cyprus.

Source: OECD, Trade in Value Added (TiVA) database, http://oe.cd/tiva, 2018. 
Table B.5. Domestic value added embodied in foreign exports, as a percentage of total gross exports (Figure 2.5)

\begin{tabular}{|c|c|c|c|c|c|c|c|}
\hline Country & 2005 & 2010 & 2015 & Country & 2005 & 2010 & 2015 \\
\hline AUS & 27.9 & 31.3 & 26.8 & ARG & 18.4 & 17.4 & 16.6 \\
\hline AUT & 19.1 & 20.2 & 21.3 & BRA & 20.3 & 23.9 & 19.6 \\
\hline BEL & 19.9 & 20.3 & 20.2 & BRN & 29.8 & 32.4 & 41.1 \\
\hline CAN & 12.6 & 15.8 & 15.3 & BGR & 13.3 & 14.1 & 16.0 \\
\hline $\mathrm{CHL}$ & 31.9 & 35.0 & 28.9 & KHM & 15.9 & 15.0 & 18.0 \\
\hline CZE & 17.9 & 17.7 & 19.4 & $\mathrm{CHN}$ & 15.6 & 16.2 & 17.5 \\
\hline DNK & 19.3 & 19.2 & 18.1 & COL & 18.3 & 22.9 & 21.9 \\
\hline EST & 17.8 & 17.9 & 16.8 & CRI & 9.3 & 10.6 & 11.4 \\
\hline FIN & 20.3 & 19.1 & 21.4 & HRV & 10.4 & 12.5 & 12.4 \\
\hline FRA & 18.5 & 19.4 & 21.2 & CYP & 13.5 & 17.6 & 16.8 \\
\hline DEU & 21.0 & 20.9 & 21.9 & IND & 16.6 & 15.4 & 14.9 \\
\hline GRC & 16.6 & 18.4 & 15.8 & IDN & 24.6 & 27.9 & 24.1 \\
\hline HUN & 14.1 & 13.2 & 16.1 & HKG & 17.6 & 15.8 & 15.7 \\
\hline ISL & 16.6 & 21.0 & 17.3 & KAZ & 31.5 & 34.8 & 35.1 \\
\hline IRL & 12.5 & 12.6 & 12.2 & MYS & 16.0 & 17.3 & 18.7 \\
\hline ISR & 15.2 & 15.7 & 17.9 & MLT & 10.4 & 6.9 & 7.0 \\
\hline ITA & 17.5 & 17.5 & 18.6 & MAR & 17.1 & 17.8 & 17.5 \\
\hline JPN & 26.4 & 25.6 & 24.4 & PER & 31.7 & 39.1 & 29.4 \\
\hline KOR & 20.6 & 17.8 & 19.1 & PHL & 20.1 & 23.0 & 22.4 \\
\hline LVA & 20.3 & 20.1 & 19.0 & ROU & 16.4 & 20.0 & 21.3 \\
\hline LTU & 15.1 & 15.4 & 16.8 & RUS & 33.5 & 33.8 & 30.5 \\
\hline LUX & 11.3 & 12.3 & 10.6 & SAU & 34.0 & 38.9 & 36.8 \\
\hline MEX & 8.3 & 10.3 & 8.8 & SGP & 20.9 & 20.6 & 20.9 \\
\hline NLD & 21.7 & 23.3 & 21.3 & ZAF & 23.8 & 24.3 & 20.1 \\
\hline NZL & 12.1 & 13.1 & 11.7 & TWN & 22.8 & 20.5 & 24.4 \\
\hline NOR & 31.9 & 33.1 & 32.1 & THA & 15.4 & 14.9 & 13.8 \\
\hline POL & 20.0 & 20.3 & 21.5 & TUN & 17.2 & 17.7 & 16.1 \\
\hline PRT & 15.2 & 15.9 & 15.4 & VNM & 14.5 & 12.5 & 11.1 \\
\hline SVK & 17.3 & 17.0 & 18.8 & ROW & 24.6 & 28.8 & 27.5 \\
\hline SVN & 15.9 & 16.9 & 20.0 & & & & \\
\hline ESP & 15.6 & 16.8 & 17.6 & & & & \\
\hline SWE & 19.8 & 20.7 & 21.5 & & & & \\
\hline $\mathrm{CHE}$ & 16.6 & 16.1 & 17.2 & & & & \\
\hline TUR & 13.5 & 15.0 & 16.6 & & & & \\
\hline GBR & 22.0 & 22.6 & 23.7 & & & & \\
\hline USA & 22.5 & 21.9 & 22.2 & & & & \\
\hline
\end{tabular}

Note by Turkey: The information in this document with reference to "Cyprus" relates to the southern part of the Island. There is no single authority representing both Turkish and Greek Cypriot people on the Island. Turkey recognises the Turkish Republic of Northern Cyprus (TRNC). Until a lasting and equitable solution is found within the context of the United Nations, Turkey shall preserve its position concerning the "Cyprus issue". Note by all the European Union Member States of the OECD and the European Union: The Republic of Cyprus is recognised by all members of the United Nations with the exception of Turkey. The information in this document relates to the area under the effective control of the Government of the Republic of Cyprus.

Source: OECD, Trade in Value Added (TiVA) database, http://oe.cd/tiva, 2018. 
Table B.6. Regional demand for manufactured goods, 2005 and 2015, by economy or region of value added origin, percentage shares of total (Figure 3.1)

\begin{tabular}{|c|c|c|c|c|c|c|}
\hline \multirow{2}{*}{ Region } & \multicolumn{2}{|c|}{ North America } & \multicolumn{2}{|c|}{ European Union } & \multicolumn{2}{|c|}{ East and Southeast Asia } \\
\hline & 2005 & 2015 & 2005 & 2015 & 2005 & 2015 \\
\hline Intra-regional & 72.2 & 69.8 & 77.7 & 71.5 & 81.5 & 83.2 \\
\hline North America & 0.0 & 0.0 & 4.4 & 5.1 & 5.0 & 4.3 \\
\hline European Union & 7.8 & 7.8 & 0.0 & 0.0 & 5.5 & 5.2 \\
\hline East and Southeast Asia & 12.3 & 15.4 & 6.8 & 10.7 & 0.0 & 0.0 \\
\hline Rest of the World & 7.7 & 7.0 & 11.1 & 12.7 & 8.0 & 7.3 \\
\hline \multicolumn{7}{|c|}{ Intra-regional: East and Southeast Asia } \\
\hline Country or Region & 2005 & 2015 & & & & \\
\hline Japan & 45.3 & 16.2 & & & & \\
\hline Korea & 7.5 & 5.2 & & & & \\
\hline China & 31.4 & 63.3 & & & & \\
\hline Chinese Taipei & 3.7 & 2.5 & & & & \\
\hline Other E\&SE Asia & 12.2 & 12.8 & & & & \\
\hline \multicolumn{7}{|l|}{ Intra-regional: Europe } \\
\hline Country or Region & 2005 & 2015 & & & & \\
\hline France & 13.3 & 12.0 & & & & \\
\hline Germany & 25.8 & 25.8 & & & & \\
\hline Italy & 14.8 & 12.5 & & & & \\
\hline United Kingdom & 11.8 & 11.8 & & & & \\
\hline EU13 & 7.9 & 10.8 & & & & \\
\hline Other EU28 & 26.3 & 27.1 & & & & \\
\hline
\end{tabular}

Source: OECD, Trade in Value Added database, http://oe.cd/tiva, 2018, Origin of value added in final demand 
Table B.7. Regional demand for manufactured goods and business services, 2005 and 2015, by economy or region of value added origin, percentage shares of total

(Figure 3.2)

\begin{tabular}{|c|c|c|c|c|c|c|}
\hline \multirow{2}{*}{ Region } & \multicolumn{2}{|c|}{ North America } & \multicolumn{2}{|c|}{ European Union } & \multicolumn{2}{|c|}{ East and Southeast Asia } \\
\hline & 2005 & 2015 & 2005 & 2015 & 2005 & 2015 \\
\hline Intra-regional & 87.4 & 86.8 & 87.9 & 85.0 & 87.7 & 87.7 \\
\hline North America & 0.0 & 0.0 & 2.9 & 3.5 & 3.4 & 3.3 \\
\hline European Union & 4.1 & 3.8 & 0.0 & 0.0 & 3.5 & 3.3 \\
\hline East and Southeast Asia & 4.7 & 6.0 & 3.0 & 4.5 & 0.0 & 0.0 \\
\hline Rest of the World & 3.7 & 3.5 & 6.2 & 7.0 & 5.4 & 5.6 \\
\hline \multicolumn{7}{|c|}{ Intra-regional: East and Southeast Asia } \\
\hline Country or Region & 2005 & 2015 & & & & \\
\hline Japan & 55.3 & 23.6 & & & & \\
\hline Korea & 8.7 & 6.1 & & & & \\
\hline China & 22.4 & 55.8 & & & & \\
\hline Chinese Taipei & 3.3 & 2.3 & & & & \\
\hline Other E\&SE Asia & 10.3 & 12.3 & & & & \\
\hline \multicolumn{7}{|l|}{ Intra-regional: Europe } \\
\hline Country or Region & 2005 & 2015 & & & & \\
\hline France & 15.2 & 15.1 & & & & \\
\hline Germany & 19.7 & 20.2 & & & & \\
\hline Italy & 13.4 & 11.7 & & & & \\
\hline United Kingdom & 17.3 & 17.9 & & & & \\
\hline EU13 & 6.4 & 8.4 & & & & \\
\hline Other EU28 & 27.9 & 26.9 & & & & \\
\hline
\end{tabular}

Source: OECD, Trade in Value Added database, http://oe.cd/tiva, 2018, Origin of value added in final demand 
Table B.8. Origin of foreign value added in domestic final demand for manufactured goods and business services. Intra-regional versus extra-regional (ROW) origin, selected countries, 2005 to 2015, USD Millions and percentage shares (Figure 3.3)

\begin{tabular}{|c|c|c|c|c|c|c|}
\hline Year & FRA-EU28 & FRA-ROW & FRA-ROW (\%) & DEU-EU28 & DEU-ROW & DEU-ROW (\%) \\
\hline 2005 & 209557 & 164731 & 44.0 & 260976 & 210700 & 44.7 \\
\hline 2006 & 221599 & 183387 & 45.3 & 280959 & 246541 & 46.7 \\
\hline 2007 & 260995 & 215315 & 45.2 & 310412 & 279575 & 47.4 \\
\hline 2008 & 286929 & 250231 & 46.6 & 338463 & 338339 & 50.0 \\
\hline 2009 & 240829 & 210499 & 46.6 & 298199 & 269226 & 47.4 \\
\hline 2010 & 246815 & 223254 & 47.5 & 307375 & 323548 & 51.3 \\
\hline 2011 & 270524 & 262136 & 49.2 & 344015 & 380294 & 52.5 \\
\hline 2012 & 251529 & 251280 & 50.0 & 318192 & 365533 & 53.5 \\
\hline 2013 & 264698 & 260007 & 49.6 & 343840 & 369014 & 51.8 \\
\hline 2014 & 274909 & 258854 & 48.5 & 355320 & 371224 & 51.1 \\
\hline 2015 & 236392 & 225623 & 48.8 & 303813 & 322202 & 51.5 \\
\hline Year & GBR-EU28 & GBR-ROW & GBR-ROW (\%) & USA - N.Am. & USA - ROW & USA-ROW (\%) \\
\hline 2005 & 222644 & 221683 & 49.9 & 262668 & 1139891 & 81.3 \\
\hline 2006 & 231604 & 245166 & 51.4 & 284443 & 1258373 & 81.6 \\
\hline 2007 & 267545 & 277871 & 50.9 & 294268 & 1331283 & 81.9 \\
\hline 2008 & 261253 & 283123 & 52.0 & 298926 & 1413595 & 82.5 \\
\hline 2009 & 202448 & 229739 & 53.2 & 223731 & 1113454 & 83.3 \\
\hline 2010 & 209603 & 253524 & 54.7 & 265406 & 1261722 & 82.6 \\
\hline 2011 & 227789 & 275521 & 54.7 & 300911 & 1421987 & 82.5 \\
\hline 2012 & 223423 & 286503 & 56.2 & 306318 & 1479512 & 82.8 \\
\hline 2013 & 238521 & 292901 & 55.1 & 313729 & 1481413 & 82.5 \\
\hline 2014 & 261648 & 304946 & 53.8 & 333749 & 1546252 & 82.2 \\
\hline 2015 & 241178 & 285336 & 54.2 & 309848 & 1536637 & 83.2 \\
\hline Year & JPN - Asia & JPN - ROW & JPN-ROW (\%) & KOR - Asia & KOR - ROW & KOR-ROW (\%) \\
\hline 2005 & 128592 & 295958 & 69.7 & 63323 & 101614 & 61.6 \\
\hline 2006 & 141749 & 324104 & 69.6 & 72496 & 121264 & 62.6 \\
\hline 2007 & 150449 & 338473 & 69.2 & 85365 & 137349 & 61.7 \\
\hline 2008 & 178915 & 412767 & 69.8 & 91553 & 149430 & 62.0 \\
\hline 2009 & 152298 & 306710 & 66.8 & 76589 & 118607 & 60.8 \\
\hline 2010 & 185703 & 359325 & 65.9 & 90037 & 151592 & 62.7 \\
\hline 2011 & 231159 & 440914 & 65.6 & 111889 & 180606 & 61.7 \\
\hline 2012 & 254027 & 468661 & 64.8 & 110143 & 185728 & 62.8 \\
\hline 2013 & 246362 & 434399 & 63.8 & 108527 & 190929 & 63.8 \\
\hline 2014 & 261344 & 440342 & 62.8 & 108683 & 196452 & 64.4 \\
\hline 2015 & 226979 & 340762 & 60.0 & 107148 & 165872 & 60.8 \\
\hline Year & CHN- Asia & $\mathrm{CHN}$ - ROW & CHN-ROW (\%) & & & \\
\hline 2005 & 151943 & 205529 & 57.5 & & & \\
\hline 2006 & 165152 & 243814 & 59.6 & & & \\
\hline 2007 & 185195 & 293399 & 61.3 & & & \\
\hline 2008 & 208092 & 386193 & 65.0 & & & \\
\hline 2009 & 221483 & 389368 & 63.7 & & & \\
\hline 2010 & 282081 & 511428 & 64.5 & & & \\
\hline 2011 & 343005 & 710818 & 67.5 & & & \\
\hline 2012 & 360602 & 795698 & 68.8 & & & \\
\hline 2013 & 385772 & 873735 & 69.4 & & & \\
\hline 2014 & 421373 & 953917 & 69.4 & & & \\
\hline 2015 & 410450 & 842717 & 67.2 & & & \\
\hline
\end{tabular}

Source: Estimation based on OECD's Inter-Country Input-Output (ICIO) Database, 2018. 
Table B.9. Domestic value added in foreign final demand for manufactured goods and business services. Intra-regional versus extra-regional (ROW) demand, selected countries, 2005 to 2015, USD Millions and percentage shares (Figure 3.4)

\begin{tabular}{|c|c|c|c|c|c|c|}
\hline Year & FRA-EU28 & FRA-ROW & FRA-ROW (\%) & DEU-EU28 & DEU-ROW & DEU-ROW (\%) \\
\hline 2005 & 203981 & 152296 & 42.7 & 316871 & 274674 & 46.4 \\
\hline 2006 & 208234 & 165087 & 44.2 & 346016 & 303671 & 46.7 \\
\hline 2007 & 238486 & 187401 & 44.0 & 418660 & 350836 & 45.6 \\
\hline 2008 & 250920 & 214646 & 46.1 & 446946 & 404444 & 47.5 \\
\hline 2009 & 202002 & 192400 & 48.8 & 353224 & 347992 & 49.6 \\
\hline 2010 & 202263 & 193811 & 48.9 & 362016 & 389152 & 51.8 \\
\hline 2011 & 219818 & 223039 & 50.4 & 392529 & 449164 & 53.4 \\
\hline 2012 & 200588 & 228291 & 53.2 & 358745 & 466519 & 56.5 \\
\hline 2013 & 212669 & 241436 & 53.2 & 377489 & 491882 & 56.6 \\
\hline 2014 & 223808 & 247690 & 52.5 & 405140 & 514108 & 55.9 \\
\hline 2015 & 195430 & 227682 & 53.8 & 359816 & 477034 & 57.0 \\
\hline Year & GBR-EU28 & GBR-ROW & GBR-ROW (\%) & USA - N.Am. & USA - ROW & USA-ROW (\%) \\
\hline 2005 & 169334 & 201520 & 54.3 & 199609 & 628617 & 75.9 \\
\hline 2006 & 184382 & 218159 & 54.2 & 221369 & 704609 & 76.1 \\
\hline 2007 & 214084 & 246361 & 53.5 & 239142 & 804586 & 77.1 \\
\hline 2008 & 211770 & 246751 & 53.8 & 251796 & 888765 & 77.9 \\
\hline 2009 & 170940 & 205962 & 54.6 & 214011 & 826955 & 79.4 \\
\hline 2010 & 174224 & 220704 & 55.9 & 253712 & 905776 & 78.1 \\
\hline 2011 & 192057 & 254968 & 57.0 & 277176 & 1005218 & 78.4 \\
\hline 2012 & 176809 & 269349 & 60.4 & 290183 & 1066497 & 78.6 \\
\hline 2013 & 185119 & 283325 & 60.5 & 298121 & 1119839 & 79.0 \\
\hline 2014 & 196647 & 299784 & 60.4 & 310411 & 1168974 & 79.0 \\
\hline 2015 & 178101 & 292081 & 62.1 & 293253 & 1163707 & 79.9 \\
\hline Year & JPN - Asia & JPN - ROW & JPN-ROW (\%) & KOR - Asia & KOR - ROW & KOR-ROW (\%) \\
\hline 2005 & 159166 & 330704 & 67.5 & 62865 & 120287 & 65.7 \\
\hline 2006 & 160133 & 345738 & 68.3 & 67164 & 133202 & 66.5 \\
\hline 2007 & 171985 & 370847 & 68.3 & 75549 & 154341 & 67.1 \\
\hline 2008 & 193551 & 397004 & 67.2 & 77134 & 156979 & 67.1 \\
\hline 2009 & 176744 & 297065 & 62.7 & 78534 & 141333 & 64.3 \\
\hline 2010 & 230588 & 355118 & 60.6 & 97453 & 165504 & 62.9 \\
\hline 2011 & 250726 & 355990 & 58.7 & 115707 & 182191 & 61.2 \\
\hline 2012 & 249802 & 362972 & 59.2 & 129128 & 187095 & 59.2 \\
\hline 2013 & 221738 & 329603 & 59.8 & 141417 & 199067 & 58.5 \\
\hline 2014 & 234264 & 338248 & 59.1 & 151721 & 206863 & 57.7 \\
\hline 2015 & 222083 & 327901 & 59.6 & 145446 & 205225 & 58.5 \\
\hline Year & $\mathrm{CHN}-\mathrm{Asia}$ & $\mathrm{CHN}$ - ROW & CHN-ROW (\%) & & & \\
\hline 2005 & 102623 & 332479 & 76.4 & & & \\
\hline 2006 & 121718 & 429042 & 77.9 & & & \\
\hline 2007 & 145511 & 569008 & 79.6 & & & \\
\hline 2008 & 176986 & 696153 & 79.7 & & & \\
\hline 2009 & 158636 & 610109 & 79.4 & & & \\
\hline 2010 & 186531 & 744301 & 80.0 & & & \\
\hline 2011 & 247695 & 899057 & 78.4 & & & \\
\hline 2012 & 280176 & 981505 & 77.8 & & & \\
\hline 2013 & 297899 & 1070844 & 78.2 & & & \\
\hline 2014 & 325223 & 1168907 & 78.2 & & & \\
\hline 2015 & 317125 & 1189914 & 79.0 & & & \\
\hline
\end{tabular}

Source: Estimation based on OECD's Inter-Country Input-Output (ICIO) Database, 2018. 
Table B.10. Foreign value added in domestic final demand for manufactured goods, intra-regional versus extra-regional (ROW) origin, selected countries, 2005 to 2015,

USD Millions and percentage shares (Figure 3.5)

\begin{tabular}{|c|c|c|c|c|c|c|}
\hline Year & FRA-EU28 & FRA-ROW & FRA-ROW (\%) & DEU-EU28 & DEU-ROW & DEU-ROW (\%) \\
\hline 2005 & 114330 & 90860 & 44.3 & 134226 & 116511 & 46.47 \\
\hline 2006 & 119308 & 99904 & 45.6 & 145273 & 141662 & 49.37 \\
\hline 2007 & 139601 & 117390 & 45.7 & 159969 & 160033 & 50.01 \\
\hline 2008 & 149765 & 134548 & 47.3 & 178999 & 199410 & 52.70 \\
\hline 2009 & 122841 & 112206 & 47.7 & 152541 & 152530 & 50.00 \\
\hline 2010 & 122481 & 117607 & 49.0 & 158949 & 192240 & 54.74 \\
\hline 2011 & 133970 & 136884 & 50.5 & 177647 & 222780 & 55.64 \\
\hline 2012 & 122737 & 130087 & 51.5 & 162937 & 209086 & 56.20 \\
\hline 2013 & 126695 & 133400 & 51.3 & 172985 & 207422 & 54.53 \\
\hline 2014 & 129417 & 133374 & 50.8 & 180029 & 211022 & 53.96 \\
\hline 2015 & 106611 & 113127 & 51.5 & 140913 & 169597 & 54.62 \\
\hline Year & GBR-EU28 & GBR-ROW & GBR-ROW (\%) & USA - N. Am. & USA - ROW & USA-ROW (\%) \\
\hline 2005 & 114556 & 113787 & 49.8 & 141058 & 664391 & 82.49 \\
\hline 2006 & 117886 & 123963 & 51.3 & 156309 & 736304 & 82.49 \\
\hline 2007 & 136481 & 141777 & 51.0 & 163288 & 783571 & 82.75 \\
\hline 2008 & 131758 & 144273 & 52.3 & 166777 & 816927 & 83.05 \\
\hline 2009 & 100922 & 113673 & 53.0 & 126961 & 648274 & 83.62 \\
\hline 2010 & 106113 & 129750 & 55.0 & 152074 & 747818 & 83.10 \\
\hline 2011 & 116120 & 141993 & 55.0 & 176740 & 851356 & 82.81 \\
\hline 2012 & 114509 & 147296 & 56.3 & 182056 & 898828 & 83.16 \\
\hline 2013 & 124027 & 149192 & 54.6 & 186736 & 890644 & 82.67 \\
\hline 2014 & 137477 & 160179 & 53.8 & 195430 & 921702 & 82.51 \\
\hline 2015 & 126434 & 145933 & 53.6 & 182925 & 912153 & 83.30 \\
\hline Year & JPN - Asia & JPN - ROW & JPN-ROW (\%) & KOR - Asia & KOR - ROW & KOR-ROW (\%) \\
\hline 2005 & 77227 & 137837 & 64.09 & 31888 & 43857 & 57.90 \\
\hline 2006 & 85573 & 153264 & 64.17 & 36298 & 52772 & 59.25 \\
\hline 2007 & 90571 & 159535 & 63.79 & 43111 & 59817 & 58.12 \\
\hline 2008 & 108043 & 193642 & 64.19 & 46356 & 61594 & 57.06 \\
\hline 2009 & 91362 & 138756 & 60.30 & 38210 & 47719 & 55.53 \\
\hline 2010 & 113856 & 166732 & 59.42 & 46915 & 62950 & 57.30 \\
\hline 2011 & 140208 & 204140 & 59.28 & 58044 & 77070 & 57.04 \\
\hline 2012 & 153434 & 214097 & 58.25 & 58528 & 78801 & 57.38 \\
\hline 2013 & 149972 & 195437 & 56.58 & 56982 & 82474 & 59.14 \\
\hline 2014 & 160068 & 194990 & 54.92 & 58169 & 86649 & 59.83 \\
\hline 2015 & 137118 & 150938 & 52.40 & 55864 & 71858 & 56.26 \\
\hline
\end{tabular}

\begin{tabular}{rrrr}
\hline Year & CHN- Asia & CHN - ROW & CHN-ROW (\%) \\
\hline 2005 & 93693 & 113158 & 54.71 \\
2006 & 101918 & 134949 & 56.97 \\
2007 & 113393 & 159158 & 58.40 \\
2008 & 129371 & 209623 & 61.84 \\
2009 & 140651 & 219969 & 61.00 \\
2010 & 186835 & 295814 & 61.29 \\
2011 & 220497 & 398435 & 64.37 \\
2012 & 226550 & 433183 & 65.66 \\
2013 & 239598 & 482345 & 66.81 \\
2014 & 257703 & 524343 & 67.05 \\
2015 & 237416 & 441525 & 65.03 \\
\hline
\end{tabular}

Source: Estimation based on OECD's Inter-Country Input-Output (ICIO) Database, 2018 
Table B.11. Domestic value added in foreign final demand for manufactured goods, intra-regional versus extra-regional (ROW) demand, selected countries, 2005 to 2015, USD Millions and percentage shares (Figure 3.6)

\begin{tabular}{rrrrrrr}
\hline Year & FRA-EU28 & FRA-ROW & FRA-ROW (\%) & DEU-EU28 & DEU-ROW & DEU-ROW (\%) \\
\hline 2005 & 107748 & 80222 & 42.7 & 188288 & 162854 & 46.4 \\
2006 & 109115 & 87057 & 44.4 & 203825 & 180820 & 47.0 \\
2007 & 123765 & 97373 & 44.0 & 247997 & 208554 & 45.7 \\
2008 & 129596 & 112599 & 46.5 & 259662 & 245338 & 48.6 \\
2009 & 101874 & 99210 & 49.3 & 197915 & 207290 & 51.2 \\
2010 & 100358 & 100881 & 50.1 & 205573 & 236034 & 53.4 \\
2011 & 107848 & 114906 & 51.6 & 225969 & 276829 & 55.1 \\
2012 & 97053 & 119083 & 55.1 & 206265 & 288219 & 58.3 \\
2013 & 102301 & 125371 & 55.1 & 218253 & 307039 & 58.5 \\
2014 & 106832 & 127211 & 54.4 & 233866 & 318906 & 57.7 \\
2015 & 91070 & 117584 & 56.4 & 202283 & 291761 & 59.1 \\
\hline
\end{tabular}

\begin{tabular}{rrrrrrr}
\hline Year & GBR-EU28 & GBR-ROW & GBR-ROW (\%) & USA - N. Am. & USA - ROW & USA-ROW (\%) \\
\hline 2005 & 72061 & 81246 & 53.0 & 101411 & 288927 & 74.0 \\
2006 & 77063 & 85005 & 52.5 & 111835 & 324530 & 74.4 \\
2007 & 87600 & 96155 & 52.3 & 120591 & 365064 & 75.2 \\
2008 & 86028 & 100191 & 53.8 & 123763 & 409099 & 76.8 \\
2009 & 67964 & 80971 & 54.4 & 99796 & 369856 & 78.8 \\
2010 & 70788 & 89679 & 55.9 & 120229 & 407375 & 77.2 \\
2011 & 78802 & 104427 & 57.0 & 133101 & 449911 & 77.2 \\
2012 & 70362 & 110420 & 61.1 & 141324 & 477155 & 77.1 \\
2013 & 73458 & 114358 & 60.9 & 143398 & 498270 & 77.7 \\
2014 & 77723 & 121489 & 61.0 & 147220 & 520558 & 78.0 \\
2015 & 66195 & 119282 & 64.3 & 137066 & 505227 & 78.7 \\
\hline
\end{tabular}

\begin{tabular}{rrrrrrr}
\hline Year & JPN - Asia & JPN - ROW & JPN-ROW (\%) & KOR - Asia & KOR - ROW & KOR-ROW (\%) \\
\hline 2005 & 96153 & 215897 & 69.2 & 38575 & 85140 & 68.8 \\
2006 & 96067 & 228829 & 70.4 & 41414 & 93792 & 69.4 \\
2007 & 103134 & 244364 & 70.3 & 46491 & 107359 & 69.8 \\
2008 & 117734 & 260495 & 68.9 & 46428 & 109012 & 70.1 \\
2009 & 108723 & 187639 & 63.3 & 49834 & 99789 & 66.7 \\
2010 & 146362 & 229437 & 61.1 & 63461 & 116715 & 64.8 \\
2011 & 157601 & 230923 & 59.4 & 74526 & 129032 & 63.4 \\
2012 & 155968 & 237769 & 60.4 & 81731 & 130911 & 61.6 \\
2013 & 135806 & 214214 & 61.2 & 90794 & 140689 & 60.8 \\
2014 & 141523 & 213825 & 60.2 & 96240 & 142711 & 59.7 \\
2015 & 129384 & 203468 & 61.1 & 89786 & 140331 & 61.0 \\
\hline
\end{tabular}

\begin{tabular}{rrrr}
\hline Year & CHN- Asia & CHN - ROW & CHN-ROW (\%) \\
\hline 2005 & 67061 & 240862 & 78.2 \\
2006 & 79615 & 309225 & 79.5 \\
2007 & 96158 & 412796 & 81.1 \\
2008 & 117414 & 500989 & 81.0 \\
2009 & 106435 & 449007 & 80.8 \\
2010 & 127635 & 548118 & 81.1 \\
2011 & 166771 & 662225 & 79.9 \\
2012 & 189708 & 720221 & 79.2 \\
2013 & 201071 & 779595 & 79.5 \\
2014 & 219686 & 844685 & 79.4 \\
2015 & 208807 & 840239 & 80.1 \\
\hline
\end{tabular}

Source: Estimation based on OECD's Inter-Country Input-Output (ICIO) Database, 2018 
Table B.12. Final destination of intermediate exports by importing region, intra-regional versus extra-regional, selected countries, 2005 to 2015, USD Million (Figure 3.7)

\begin{tabular}{|c|c|c|c|c|c|c|c|}
\hline \multirow{2}{*}{ FRA } & \multicolumn{3}{|c|}{ INTRA } & \multicolumn{3}{|c|}{ ROW } & \multirow{2}{*}{ TOTAL } \\
\hline & $D O M$ & INTRAREG & ROW & DOM & INTRAREG & ROW & \\
\hline 2005 & 7159 & 131529 & 28779 & 1766 & 8415 & 99800 & 277449 \\
\hline 2006 & 7501 & 139489 & 32549 & 1805 & 9275 & 110582 & 301201 \\
\hline 2007 & 8824 & 162321 & 38981 & 2207 & 10853 & 124728 & 347915 \\
\hline 2008 & 9642 & 173299 & 44572 & 2354 & 12128 & 145608 & 387601 \\
\hline 2009 & 6592 & 128141 & 31928 & 1864 & 9053 & 125222 & 302800 \\
\hline 2010 & 7974 & 143282 & 41116 & 1865 & 9418 & 132996 & 336651 \\
\hline 2011 & 9553 & 161708 & 50978 & 2204 & 10875 & 159111 & 394430 \\
\hline 2012 & 8419 & 145006 & 50933 & 2047 & 9875 & 160860 & 377141 \\
\hline 2013 & 8977 & 152556 & 54050 & 2169 & 9900 & 166728 & 394379 \\
\hline 2014 & 9518 & 160331 & 55712 & 2117 & 9850 & 169420 & 406948 \\
\hline 2015 & 7904 & 140823 & 48908 & 1754 & 8322 & 151665 & 359376 \\
\hline \multirow{2}{*}{ DEU } & \multicolumn{3}{|c|}{ INTRA } & \multicolumn{3}{|c|}{ ROW } & \multirow{2}{*}{ TOTAL } \\
\hline & DOM & INTRAREG & ROW & DOM & INTRAREG & ROW & \\
\hline 2005 & 16325 & 207483 & 48914 & 3690 & 14395 & 185905 & 476712 \\
\hline 2006 & 18842 & 239013 & 60420 & 4417 & 16451 & 209231 & 548375 \\
\hline 2007 & 21853 & 291183 & 75037 & 5587 & 20581 & 247044 & 661285 \\
\hline 2008 & 23837 & 310139 & 84724 & 6537 & 22746 & 278256 & 726239 \\
\hline 2009 & 17442 & 232040 & 60833 & 4815 & 16594 & 228760 & 560485 \\
\hline 2010 & 21424 & 253279 & 78122 & 5860 & 18140 & 268894 & 645721 \\
\hline 2011 & 25858 & 281566 & 95770 & 6852 & 20069 & 317671 & 747786 \\
\hline 2012 & 23005 & 254004 & 98020 & 6082 & 18360 & 325278 & 724749 \\
\hline 2013 & 25136 & 262578 & 101143 & 6392 & 19102 & 334254 & 748604 \\
\hline 2014 & 27303 & 280269 & 105567 & 6051 & 19146 & 345756 & 784093 \\
\hline 2015 & 22213 & 250783 & 92425 & 5048 & 16817 & 314925 & 702212 \\
\hline \multirow{2}{*}{ GBR } & \multicolumn{3}{|c|}{ INTRA } & \multicolumn{3}{|c|}{ ROW } & \multirow{2}{*}{ TOTAL } \\
\hline & DOM & INTRAREG & ROW & DOM & INTRAREG & ROW & \\
\hline 2005 & 7076 & 124199 & 29421 & 1945 & 8409 & 138789 & 309839 \\
\hline 2006 & 7886 & 140327 & 35786 & 2073 & 8921 & 148947 & 343939 \\
\hline 2007 & 9477 & 163303 & 43876 & 2380 & 11137 & 170467 & 400639 \\
\hline 2008 & 9200 & 164467 & 45930 & 2171 & 11531 & 177162 & 410461 \\
\hline 2009 & 6436 & 133860 & 35395 & 1569 & 8192 & 144786 & 330237 \\
\hline 2010 & 7108 & 140096 & 40922 & 1700 & 8634 & 159083 & 357542 \\
\hline 2011 & 8301 & 157111 & 51020 & 1798 & 10038 & 184874 & 413142 \\
\hline 2012 & 8655 & 145141 & 52464 & 1887 & 9545 & 196279 & 413971 \\
\hline 2013 & 8989 & 147375 & 53384 & 1948 & 9957 & 201096 & 422750 \\
\hline 2014 & 9705 & 153869 & 55869 & 2027 & 9899 & 203569 & 434937 \\
\hline 2015 & 9012 & 134150 & 50286 & 1873 & 8685 & 190973 & 394980 \\
\hline \multirow{2}{*}{ USA } & \multicolumn{3}{|c|}{ INTRA } & \multicolumn{3}{|c|}{ ROW } & \multirow{2}{*}{ TOTAL } \\
\hline & DOM & INTRAREG & ROW & DOM & INTRAREG & ROW & \\
\hline 2005 & 58063 & 94200 & 17021 & 36007 & 5552 & 418376 & 629220 \\
\hline 2006 & 62149 & 102872 & 19842 & 40420 & 6700 & 482486 & 714469 \\
\hline 2007 & 61197 & 109848 & 23704 & 41446 & 7175 & 560884 & 804254 \\
\hline 2008 & 62106 & 121243 & 28327 & 42072 & 7826 & 642033 & 903607 \\
\hline 2009 & 45055 & 98967 & 20796 & 32858 & 5886 & 562864 & 766428 \\
\hline 2010 & 57446 & 115248 & 25841 & 39248 & 7431 & 648051 & 893265 \\
\hline 2011 & 64199 & 132267 & 31888 & 43380 & 8611 & 761674 & 1042019 \\
\hline 2012 & 68158 & 137948 & 34374 & 44191 & 8802 & 784391 & 1077864 \\
\hline 2013 & 71281 & 140244 & 35031 & 43901 & 8911 & 808242 & 1107611 \\
\hline 2014 & 76565 & 150076 & 35276 & 46303 & 8844 & 828725 & 1145788 \\
\hline 2015 & 74299 & 138478 & 29068 & 48594 & 8421 & 781294 & 1080152 \\
\hline
\end{tabular}

Continue ... 
Table B.12. continued

\begin{tabular}{|c|c|c|c|c|c|c|c|}
\hline \multirow{2}{*}{ JPN } & \multicolumn{3}{|c|}{ INTRA } & \multicolumn{3}{|c|}{ ROW } & \multirow{2}{*}{ TOTAL } \\
\hline & DOM & INTRAREG & ROW & DOM & INTRAREG & ROW & \\
\hline 2005 & 9154 & 116287 & 65981 & 2149 & 4316 & 172807 & 370694 \\
\hline 2006 & 9057 & 125132 & 73994 & 2219 & 4907 & 183834 & 399142 \\
\hline 2007 & 8872 & 138392 & 84298 & 2313 & 5706 & 202552 & 442134 \\
\hline 2008 & 10282 & 158987 & 90690 & 2756 & 6888 & 216788 & 486391 \\
\hline 2009 & 6840 & 133091 & 65500 & 1629 & 4892 & 156308 & 368259 \\
\hline 2010 & 9403 & 170684 & 85638 & 2094 & 7031 & 189011 & 463860 \\
\hline 2011 & 11018 & 195676 & 94038 & 2524 & 8957 & 197029 & 509241 \\
\hline 2012 & 11203 & 188726 & 88253 & 2584 & 9073 & 197733 & 497572 \\
\hline 2013 & 8999 & 173534 & 77857 & 2189 & 8853 & 178735 & 450168 \\
\hline 2014 & 9371 & 183248 & 79644 & 2280 & 9732 & 188758 & 473032 \\
\hline 2015 & 7555 & 165292 & 69343 & 1863 & 8289 & 172634 & 424975 \\
\hline \multirow{2}{*}{ KOR } & \multicolumn{3}{|c|}{ INTRA } & \multicolumn{3}{|c|}{ ROW } & \multirow{2}{*}{ TOTAL } \\
\hline & DOM & INTRAREG & ROW & DOM & INTRAREG & ROW & \\
\hline 2005 & 1757 & 71340 & 38809 & 415 & 2901 & 84170 & 199392 \\
\hline 2006 & 2181 & 79719 & 47488 & 501 & 3359 & 95035 & 228284 \\
\hline 2007 & 2575 & 91024 & 58182 & 611 & 3907 & 111593 & 267891 \\
\hline 2008 & 2520 & 107014 & 57627 & 690 & 5165 & 128447 & 301463 \\
\hline 2009 & 1644 & 94314 & 43773 & 466 & 4031 & 106001 & 250231 \\
\hline 2010 & 2200 & 117053 & 57601 & 684 & 5569 & 129538 & 312645 \\
\hline 2011 & 3246 & 156474 & 68969 & 879 & 7582 & 153727 & 390876 \\
\hline 2012 & 3133 & 169906 & 73237 & 867 & 8321 & 155578 & 411042 \\
\hline 2013 & 3035 & 175009 & 77009 & 857 & 8629 & 153017 & 417557 \\
\hline 2014 & 3051 & 178645 & 77239 & 873 & 9058 & 156586 & 425451 \\
\hline 2015 & 2968 & 160310 & 70630 & 717 & 7314 & 140536 & 382476 \\
\hline \multirow{2}{*}{$\mathrm{CHN}$} & \multicolumn{3}{|c|}{ INTRA } & \multicolumn{3}{|c|}{ ROW } & \multirow{2}{*}{ TOTAL } \\
\hline & DOM & INTRAREG & ROW & DOM & INTRAREG & ROW & \\
\hline 2005 & 8010 & 87657 & 36980 & 2234 & 5879 & 233938 & 374698 \\
\hline 2006 & 10215 & 104315 & 47122 & 3193 & 7623 & 305718 & 478185 \\
\hline 2007 & 13087 & 122434 & 59158 & 4488 & 9307 & 394064 & 602538 \\
\hline 2008 & 16687 & 144632 & 69900 & 6501 & 12348 & 484050 & 734118 \\
\hline 2009 & 15280 & 116862 & 52785 & 5537 & 8156 & 380189 & 578809 \\
\hline 2010 & 20271 & 143521 & 64991 & 8161 & 11446 & 484096 & 732486 \\
\hline 2011 & 29071 & 198091 & 85647 & 12542 & 15543 & 594633 & 935527 \\
\hline 2012 & 29896 & 210437 & 87355 & 14173 & 17248 & 639953 & 999062 \\
\hline 2013 & 34928 & 216854 & 91870 & 17172 & 18392 & 709015 & 1088230 \\
\hline 2014 & 40691 & 234240 & 100531 & 21017 & 19385 & 773104 & 1188968 \\
\hline 2015 & 40970 & 228206 & 97793 & 20535 & 18488 & 800053 & 1206043 \\
\hline
\end{tabular}

Source: Estimations based on OECD's Inter-Country Input-Output (ICIO) Database, 2018 
Table B.13. Foreign value added embodied in domestic final demand by sector, global average, 2015. As a percentage of total domestic demand (Figure 4.1)

\begin{tabular}{lrrrr}
\hline \multirow{2}{*}{ Industry } & \multicolumn{3}{c}{ 2015 } & \multirow{2}{*}{2005} \\
\cline { 2 - 4 } & OECD & NON-OECD & Total & \\
\hline Agriculture & 7.8 & 6.8 & 14.6 & 16.6 \\
Mining, energy & 11.5 & 17.0 & 28.6 & 42.7 \\
Mining, non-energy & 8.8 & 6.3 & 15.1 & 20.0 \\
Mining, services & 8.9 & 4.7 & 13.6 & 14.1 \\
Food products & 13.7 & 10.0 & 23.6 & 23.7 \\
Textiles \& apparel & 14.2 & 33.7 & 47.9 & 48.6 \\
Wood & 21.6 & 16.0 & 37.5 & 39.3 \\
Paper and printing & 22.8 & 10.9 & 33.6 & 32.4 \\
Coke, petroleum & 18.0 & 29.2 & 47.2 & 52.5 \\
Chemicals & 29.1 & 12.7 & 41.8 & 42.0 \\
Rubber \& plastics & 25.6 & 17.5 & 43.1 & 40.8 \\
Non-metal minerals & 17.3 & 14.5 & 31.8 & 29.7 \\
Basic metals & 22.0 & 20.7 & 42.7 & 43.6 \\
Fabricated metals & 24.0 & 14.9 & 38.8 & 37.0 \\
ICT \& electronics & 28.4 & 30.0 & 58.4 & 53.1 \\
Electrical machinery & 24.9 & 22.2 & 47.1 & 44.7 \\
Machinery & 28.9 & 14.7 & 43.6 & 48.9 \\
Motor vehicles & 35.2 & 12.0 & 47.2 & 50.3 \\
Other transport & 37.2 & 14.9 & 52.1 & 49.3 \\
Other manufacturing & 20.5 & 21.4 & 41.9 & 36.7 \\
Utilities & 7.8 & 8.9 & 16.7 & 17.4 \\
Construction & 8.6 & 6.8 & 15.5 & 15.7 \\
Wholesale \& retail & 13.1 & 5.7 & 18.9 & 18.4 \\
Transport \& storage & 18.0 & 10.9 & 28.9 & 28.8 \\
Accommodation \& food & 14.2 & 7.4 & 21.5 & 19.9 \\
Publishing, broadcasting & 11.8 & 3.8 & 15.6 & 15.5 \\
Telecoms & 9.8 & 6.5 & 16.2 & 14.0 \\
IT services & 13.6 & 8.5 & 22.2 & 14.4 \\
Finance \& insurance & 9.6 & 2.7 & 12.4 & 10.8 \\
Real estate & 2.9 & 1.4 & 4.3 & 4.0 \\
Other business services & 15.3 & 4.8 & 20.2 & 16.0 \\
Public admin & 4.5 & 3.0 & 7.6 & 7.5 \\
Education & 4.4 & 1.9 & 6.3 & 5.1 \\
Health & 4.4 & 2.7 & 7.1 & 6.3 \\
Other services & 6.4 & 4.2 & 10.6 & 9.5 \\
Private households & 0.0 & 0.0 & 0.0 & 0.0 \\
\hline & & & & \\
\hline
\end{tabular}

Source: OECD, Trade in Value Added database, http://oe.cd/tiva, 2018, Origin of value added in final demand 
Table B.14. Foreign value added embodied in domestic final demand, by sector, OECD average, 2015. As a percentage of total domestic demand (Figure 4.2)

\begin{tabular}{lrrrr}
\hline \multirow{2}{*}{\multicolumn{1}{c}{ Industry }} & \multicolumn{3}{c}{ 2015 } & \multirow{2}{*}{2005} \\
\cline { 2 - 4 } & OECD & NON-OECD & Total & \\
\hline Agriculture & 16.1 & 10.4 & 26.5 & 23.3 \\
Mining, energy & 22.1 & 28.4 & 50.5 & 50.6 \\
Mining, non-energy & 9.7 & 6.2 & 15.9 & 21.7 \\
Mining, services & 11.0 & 4.7 & 15.7 & 14.4 \\
Food products & 18.3 & 9.8 & 28.1 & 24.7 \\
Textiles \& apparel & 18.7 & 48.5 & 67.1 & 56.5 \\
Wood & 25.7 & 15.8 & 41.4 & 39.6 \\
Paper and printing & 23.1 & 8.9 & 32.0 & 30.9 \\
Coke \& petroleum & 22.1 & 32.7 & 54.8 & 55.2 \\
Chemicals & 32.5 & 11.4 & 43.9 & 41.5 \\
Rubber \& plastics & 27.9 & 15.9 & 43.8 & 40.2 \\
Non-metal minerals & 21.7 & 14.4 & 36.1 & 29.4 \\
Basic metals & 26.2 & 23.7 & 49.9 & 44.9 \\
Fabricated metals & 26.4 & 13.9 & 40.3 & 35.0 \\
ICT \& electronics & 29.0 & 31.7 & 60.7 & 50.0 \\
Electrical machinery & 28.6 & 27.7 & 56.2 & 43.4 \\
Machinery & 35.0 & 16.2 & 51.2 & 46.0 \\
Motor vehicles & 41.4 & 12.1 & 53.5 & 51.1 \\
Other transport & 38.4 & 13.7 & 52.1 & 47.2 \\
Other manufacturing & 22.2 & 24.0 & 46.3 & 37.1 \\
Utilities & 9.1 & 9.0 & 18.0 & 17.7 \\
Construction & 9.6 & 6.2 & 15.8 & 14.4 \\
Wholesale \& retail & 12.9 & 5.0 & 17.9 & 17.2 \\
Transport \& storage & 17.9 & 9.7 & 27.6 & 27.5 \\
Accommodation \& food & 13.6 & 5.6 & 19.2 & 18.1 \\
Publishing \& broadcasting & 11.0 & 3.0 & 14.0 & 15.1 \\
Telecoms & 9.3 & 5.8 & 15.2 & 13.1 \\
IT services & 13.6 & 8.5 & 22.1 & 13.5 \\
Finance \& insurance & 9.7 & 2.5 & 12.2 & 10.4 \\
Real estate & 2.9 & 1.2 & 4.1 & 3.7 \\
Other business services & 14.8 & 4.2 & 19.0 & 14.6 \\
Public admin & 4.4 & 2.8 & 7.2 & 7.0 \\
Education & 4.0 & 1.5 & 5.4 & 4.3 \\
Health & 4.0 & 2.3 & 6.3 & 5.7 \\
Other services & 6.0 & 3.5 & 9.5 & 8.5 \\
Private households & 0.0 & 0.0 & 0.0 & 0.0 \\
\hline & & & & \\
\hline & & & & \\
\hline
\end{tabular}

Source: OECD, Trade in Value Added database, http://oe.cd/tiva, 2018, Origin of value added in final demand 
Table B.15. Global demand for Textiles and apparel, by country or region of final demand and origin of value added, percentage shares of total, 2005 and 2015

(Figure 4.3)

\begin{tabular}{lrrrr}
\hline \multirow{2}{*}{ Country or Region } & \multicolumn{2}{c}{ Final demand } & \multicolumn{2}{c}{ Value added } \\
\cline { 2 - 5 } & \multicolumn{1}{c}{2005} & 2015 & 2005 & \multicolumn{1}{c}{2015} \\
\hline North America & 25.6 & 18.3 & 13.6 & 7.5 \\
EU28 & 30.3 & 20.0 & 26.9 & 14.6 \\
Japan & 4.4 & 2.5 & 3.6 & 1.5 \\
Korea & 2.0 & 1.8 & 2.4 & 1.8 \\
China & 6.2 & 13.7 & 16.1 & 31.2 \\
Other E\&SE Asia & 4.2 & 5.8 & 7.1 & 7.6 \\
Brazil & 2.5 & 3.3 & 2.7 & 2.9 \\
India & 3.8 & 6.3 & 5.1 & 7.3 \\
Rest of the world & 21.1 & 28.4 & 22.4 & 25.6 \\
\hline
\end{tabular}

Source: OECD, Trade in Value Added database, http://oe.cd/tiva, 2018, Origin of value added in final demand

Table B.16. Regional demand for Textiles and apparel by economy or region of value added origin, percentage shares of total, 2005 and 2015 (Figure 4.4)

\begin{tabular}{|c|c|c|c|c|c|c|}
\hline \multirow{2}{*}{ Region } & \multicolumn{2}{|c|}{ North America } & \multicolumn{2}{|c|}{ European Union } & \multicolumn{2}{|c|}{ East and Southeast Asia } \\
\hline & 2005 & 2015 & 2005 & 2015 & 2005 & 2015 \\
\hline Intra-regional & 45.8 & 32.3 & 69.8 & 52.3 & 85.3 & 88.3 \\
\hline North America & 0.0 & 0.0 & 1.9 & 1.9 & 2.5 & 1.8 \\
\hline European Union & 7.8 & 5.3 & 0.0 & 0.0 & 5.7 & 3.7 \\
\hline East and Southeast Asia & 29.8 & 46.3 & 12.3 & 25.7 & 0.0 & 0.0 \\
\hline Rest of the World & 16.6 & 16.1 & 15.9 & 20.1 & 6.5 & 6.2 \\
\hline \multicolumn{7}{|c|}{ Intra-regional: East and Southeast Asia } \\
\hline Country or Region & 2005 & 2015 & & & & \\
\hline Japan & 18.8 & 4.8 & & & & \\
\hline Korea & 10.2 & 5.7 & & & & \\
\hline China & 48.7 & 69.6 & & & & \\
\hline Chinese Taipei & 4.1 & 1.6 & & & & \\
\hline Other E\&SE Asia & 18.2 & 18.3 & & & & \\
\hline \multicolumn{7}{|l|}{ Intra-regional: Europe } \\
\hline Country or Region & 2005 & 2015 & & & & \\
\hline France & 10.6 & 8.4 & & & & \\
\hline Germany & 13.9 & 13.0 & & & & \\
\hline Italy & 32.1 & 34.6 & & & & \\
\hline United Kingdom & 9.1 & 11.7 & & & & \\
\hline EU13 & 8.4 & 9.8 & & & & \\
\hline Other EU28 & 25.9 & 22.5 & & & & \\
\hline
\end{tabular}

Source: Trade in Value Added database, http://oe.cd/tiva, 2018, Origin of value added in final demand 
Table B.17. Foreign value added embodied in domestic demand for Textiles and apparel by source region, as a percentage of total domestic demand (Figure 4.5)

\begin{tabular}{|c|c|c|c|c|c|c|c|}
\hline \multirow[b]{2}{*}{ Country } & \multicolumn{6}{|c|}{2015} & \multirow[b]{2}{*}{2005} \\
\hline & EU28 & N. Am. & $\mathrm{CHN}$ & $\begin{array}{c}\text { Other } \\
\text { E\&SE Asia }\end{array}$ & ROW & Total & \\
\hline AUS & 5.6 & 2.7 & 54.8 & 9.4 & 14.4 & 87.0 & 67.6 \\
\hline AUT & 31.9 & 1.9 & 22.0 & 5.2 & 22.6 & 83.6 & 73.7 \\
\hline BEL & 28.1 & 3.1 & 22.6 & 6.0 & 22.8 & 82.5 & 77.8 \\
\hline CAN & 6.4 & 9.6 & 46.0 & 10.0 & 18.2 & 90.3 & 68.7 \\
\hline $\mathrm{CHL}$ & 3.7 & 2.9 & 55.8 & 5.5 & 13.8 & 81.6 & 72.3 \\
\hline CZE & 29.8 & 1.8 & 28.2 & 6.1 & 21.8 & 87.7 & 69.7 \\
\hline DNK & 29.4 & 1.9 & 24.8 & 5.0 & 21.3 & 82.4 & 71.9 \\
\hline EST & 31.7 & 1.7 & 27.7 & 4.5 & 17.1 & 82.7 & 72.4 \\
\hline FIN & 21.3 & 2.0 & 28.9 & 5.5 & 18.7 & 76.5 & 68.2 \\
\hline FRA & 21.4 & 1.9 & 27.1 & 5.3 & 21.2 & 76.9 & 62.2 \\
\hline DEU & 20.3 & 2.1 & 23.3 & 5.8 & 23.0 & 74.4 & 61.1 \\
\hline GRC & 34.9 & 1.7 & 19.2 & 3.8 & 20.3 & 79.9 & 57.9 \\
\hline HUN & 55.9 & 1.8 & 8.5 & 3.8 & 15.3 & 85.2 & 77.6 \\
\hline ISL & 25.7 & 4.9 & 26.2 & 6.0 & 19.2 & 82.1 & 72.4 \\
\hline IRL & 37.1 & 3.3 & 27.3 & 4.8 & 22.0 & 94.7 & 88.1 \\
\hline ISR & 14.6 & 4.0 & 30.3 & 6.4 & 15.5 & 70.8 & 69.8 \\
\hline ITA & 13.9 & 1.4 & 11.5 & 2.7 & 13.0 & 42.4 & 37.2 \\
\hline JPN & 5.3 & 1.8 & 46.9 & 9.1 & 7.4 & 70.4 & 48.7 \\
\hline KOR & 6.7 & 2.9 & 22.4 & 10.3 & 8.8 & 51.0 & 43.4 \\
\hline LVA & 56.5 & 1.8 & 10.4 & 2.4 & 12.8 & 83.9 & 76.9 \\
\hline LTU & 39.0 & 1.2 & 9.4 & 1.8 & 12.9 & 64.3 & 48.3 \\
\hline LUX & 31.5 & 4.2 & 11.2 & 4.8 & 11.1 & 62.9 & 60.0 \\
\hline MEX & 4.8 & 12.2 & 18.4 & 5.3 & 10.2 & 50.8 & 37.3 \\
\hline NLD & 28.3 & 2.7 & 23.8 & 6.4 & 20.7 & 81.8 & 73.9 \\
\hline NZL & 5.4 & 2.4 & 45.2 & 7.7 & 11.6 & 72.4 & 61.4 \\
\hline NOR & 21.4 & 2.1 & 35.9 & 6.6 & 20.5 & 86.7 & 79.8 \\
\hline POL & 19.0 & 1.5 & 30.3 & 5.0 & 22.0 & 77.8 & 54.4 \\
\hline PRT & 36.2 & 1.2 & 6.7 & 2.3 & 10.9 & 57.4 & 49.0 \\
\hline SVK & 24.9 & 1.6 & 25.8 & 7.5 & 28.9 & 88.7 & 83.1 \\
\hline SVN & 27.4 & 1.7 & 25.2 & 5.3 & 26.6 & 86.2 & 73.9 \\
\hline ESP & 18.0 & 1.6 & 24.5 & 4.8 & 25.9 & 74.7 & 52.0 \\
\hline SWE & 27.4 & 2.2 & 26.4 & 7.5 & 21.5 & 85.0 & 79.8 \\
\hline CHE & 33.6 & 2.2 & 28.0 & 7.4 & 19.5 & 90.8 & 91.2 \\
\hline TUR & 6.8 & 1.1 & 9.6 & 3.6 & 10.5 & 31.6 & 27.6 \\
\hline GBR & 17.0 & 2.3 & 27.2 & 5.3 & 24.6 & 76.4 & 72.6 \\
\hline USA & 5.2 & 2.4 & 36.5 & 11.1 & 16.5 & 71.8 & 61.4 \\
\hline
\end{tabular}


Table B.17. continued

\begin{tabular}{|c|c|c|c|c|c|c|c|}
\hline \multirow[b]{2}{*}{ Country } & \multicolumn{6}{|c|}{2015} & \multirow[b]{2}{*}{2005} \\
\hline & EU28 & N. Am. & $\mathrm{CHN}$ & $\begin{array}{c}\text { Other } \\
\text { E\&SE Asia }\end{array}$ & ROW & Total & \\
\hline ARG & 1.3 & 1.4 & 3.6 & 1.1 & 3.8 & 11.3 & 17.2 \\
\hline BRA & 2.9 & 2.1 & 11.8 & 3.0 & 5.0 & 24.8 & 14.1 \\
\hline BRN & 3.0 & 1.5 & 8.4 & 11.9 & 3.6 & 28.5 & 48.2 \\
\hline BGR & 27.6 & 1.2 & 3.5 & 1.4 & 12.5 & 46.3 & 43.1 \\
\hline KHM & 2.0 & 1.1 & 35.5 & 14.6 & 4.4 & 57.6 & 71.8 \\
\hline $\mathrm{CHN}$ & 2.6 & 1.5 & 0.0 & 4.9 & 5.3 & 14.2 & 20.8 \\
\hline COL & 3.0 & 4.2 & 20.6 & 4.2 & 10.1 & 42.2 & 28.1 \\
\hline CRI & 3.9 & 9.8 & 22.2 & 3.3 & 30.5 & 69.8 & 68.8 \\
\hline HRV & 52.1 & 1.2 & 6.8 & 1.7 & 12.1 & 73.9 & 65.1 \\
\hline CYP & 59.8 & 1.7 & 11.2 & 2.9 & 15.2 & 90.8 & 79.7 \\
\hline IND & 2.6 & 1.5 & 8.1 & 3.6 & 7.2 & 23.0 & 23.4 \\
\hline IDN & 2.2 & 1.5 & 11.8 & 10.8 & 5.5 & 31.8 & 28.2 \\
\hline HKG & 8.7 & 2.4 & 44.9 & 6.7 & 6.8 & 69.5 & 71.8 \\
\hline KAZ & 8.4 & 1.9 & 31.4 & 3.9 & 36.1 & 81.8 & 68.1 \\
\hline MYS & 4.9 & 2.6 & 27.3 & 14.9 & 9.9 & 59.6 & 70.2 \\
\hline MLT & 47.4 & 3.5 & 11.6 & 3.7 & 14.5 & 80.7 & 78.5 \\
\hline MAR & 25.9 & 1.3 & 14.4 & 3.0 & 12.6 & 57.2 & 64.3 \\
\hline PER & 2.4 & 3.3 & 20.6 & 3.6 & 9.7 & 39.5 & 26.0 \\
\hline PHL & 2.3 & 1.7 & 11.0 & 9.7 & 4.1 & 28.8 & 27.0 \\
\hline ROU & 38.7 & 1.0 & 5.7 & 1.7 & 9.3 & 56.5 & 72.3 \\
\hline RUS & 12.0 & 1.7 & 33.2 & 6.9 & 19.7 & 73.5 & 55.6 \\
\hline SAU & 6.5 & 2.2 & 30.0 & 6.6 & 20.6 & 65.8 & 59.9 \\
\hline SGP & 11.6 & 4.6 & 23.8 & 28.7 & 15.7 & 84.4 & 88.4 \\
\hline ZAF & 6.1 & 2.0 & 31.8 & 5.9 & 19.6 & 65.4 & 44.4 \\
\hline TWN & 6.7 & 3.1 & 29.2 & 14.3 & 13.2 & 66.5 & 54.4 \\
\hline THA & 3.6 & 1.9 & 10.8 & 7.4 & 7.5 & 31.2 & 32.3 \\
\hline TUN & 27.7 & 1.1 & 6.4 & 2.0 & 13.0 & 50.2 & 57.5 \\
\hline VNM & 4.4 & 2.7 & 26.1 & 18.6 & 9.6 & 61.4 & 62.0 \\
\hline ROW & 6.8 & 2.6 & 14.7 & 4.9 & 7.3 & 36.3 & 36.3 \\
\hline
\end{tabular}

Note by Turkey: The information in this document with reference to "Cyprus" relates to the southern part of the Island. There is no single authority representing both Turkish and Greek Cypriot people on the Island. Turkey recognises the Turkish Republic of Northern Cyprus (TRNC). Until a lasting and equitable solution is found within the context of the United Nations, Turkey shall preserve its position concerning the "Cyprus issue".

Note by all the European Union Member States of the OECD and the European Union: The Republic of Cyprus is recognised by all members of the United Nations with the exception of Turkey. The information in this document relates to the area under the effective control of the Government of the Republic of Cyprus.

Source: OECD, Trade in Value Added (TiVA) database, http://oe.cd/tiva, 2018, Origin of value added in final demand 
Table B.18. Global demand for Chemical and pharmaceutical products, by country or region of final demand and origin of value added, percentage shares of total, 2005 and 2015 (Figure 4.6)

\begin{tabular}{lrrrr}
\hline \multicolumn{1}{c}{ Country or } & \multicolumn{2}{c}{ Final demand } & \multicolumn{2}{c}{ Value added } \\
\cline { 2 - 5 } \multicolumn{1}{c}{ Region } & 2005 & \multicolumn{1}{c}{2015} & 2005 & \multicolumn{1}{c}{2015} \\
\hline North America & 36.3 & 33.0 & 31.5 & 29.2 \\
EU28 & 31.5 & 20.2 & 32.0 & 23.7 \\
Japan & 8.4 & 6.5 & 8.4 & 5.6 \\
Korea & 1.3 & 1.1 & 1.3 & 1.4 \\
China & 5.8 & 16.1 & 5.5 & 15.8 \\
Other E\&SE Asia & 2.3 & 2.6 & 2.7 & 3.1 \\
Brazil & 1.8 & 3.2 & 1.6 & 2.4 \\
India & 1.2 & 1.9 & 1.3 & 2.1 \\
Rest of the world & 11.4 & 15.2 & 15.6 & 16.7 \\
\hline
\end{tabular}

Source: OECD, Trade in Value Added database, http://oe.cd/tiva, 2018, Origin of value added in final demand

Table B.19. Regional demand for Chemical and pharmaceutical products, by economy or region of value added origin, percentage shares of total, 2005 and 2015

(Figure 4.7)

\begin{tabular}{|c|c|c|c|c|c|c|}
\hline \multirow{2}{*}{ Region } & \multicolumn{2}{|c|}{ North America } & \multicolumn{2}{|c|}{ European Union } & \multicolumn{2}{|c|}{ East and Southeast Asia } \\
\hline & 2005 & 2015 & 2005 & 2015 & 2005 & 2015 \\
\hline Intra-regional & 75.8 & 74.3 & 76.0 & 70.4 & 79.2 & 78.6 \\
\hline North America & 0.0 & 0.0 & 6.7 & 8.9 & 4.4 & 4.6 \\
\hline European Union & 11.2 & 11.7 & 0.0 & 0.0 & 6.3 & 7.4 \\
\hline East and Southeast Asia & 4.8 & 6.1 & 3.7 & 5.7 & 0.0 & 0.0 \\
\hline Rest of the World & 8.2 & 7.9 & 13.6 & 15.1 & 10.0 & 9.5 \\
\hline \multicolumn{7}{|c|}{ Intra-regional: East and Southeast Asia } \\
\hline Country or Region & 2005 & 2015 & & & & \\
\hline Japan & 50.6 & 22.8 & & & & \\
\hline Korea & 6.8 & 4.3 & & & & \\
\hline China & 31.4 & 63.6 & & & & \\
\hline Chinese Taipei & 2.2 & 1.4 & & & & \\
\hline Other E\&SE Asia & 9.1 & 7.9 & & & & \\
\hline \multicolumn{7}{|l|}{ Intra-regional: Europe } \\
\hline Country or Region & 2005 & 2015 & & & & \\
\hline France & 13.3 & 12.0 & & & & \\
\hline Germany & 24.7 & 22.0 & & & & \\
\hline Italy & 10.3 & 9.5 & & & & \\
\hline United Kingdom & 14.7 & 14.1 & & & & \\
\hline EU13 & 5.0 & 6.5 & & & & \\
\hline Other EU28 & 32.0 & 35.9 & & & & \\
\hline
\end{tabular}

Source: OECD, Trade in Value Added database, http://oe.cd/tiva, 2018, Origin of value added in final demand 
Table B.20. Foreign value added embodied in domestic demand for Chemical and pharmaceutical products, by source region, 2015, as a percentage of total domestic demand (Figure 4.8)

\begin{tabular}{|c|c|c|c|c|c|c|c|}
\hline \multirow[b]{2}{*}{ Country } & \multicolumn{6}{|c|}{2015} & \multirow[b]{2}{*}{2005} \\
\hline & EU28 & N. Am. & $\mathrm{CHN}$ & $\begin{array}{c}\text { Other } \\
\text { E\&SE Asia }\end{array}$ & ROW & Total & \\
\hline AUS & 18.5 & 8.7 & 4.9 & 6.2 & 23.0 & 61.2 & 61.0 \\
\hline AUT & 39.1 & 11.1 & 2.3 & 2.2 & 22.2 & 76.9 & 72.2 \\
\hline BEL & 30.7 & 8.0 & 1.8 & 3.6 & 9.9 & 54.1 & 44.4 \\
\hline CAN & 13.4 & 32.5 & 3.1 & 2.5 & 12.4 & 63.9 & 58.5 \\
\hline $\mathrm{CHL}$ & 13.5 & 18.4 & 9.5 & 4.0 & 20.0 & 65.4 & 60.1 \\
\hline CZE & 47.8 & 5.2 & 2.6 & 2.5 & 15.3 & 73.4 & 76.3 \\
\hline DNK & 28.5 & 3.2 & 1.6 & 1.5 & 9.8 & 44.7 & 55.9 \\
\hline EST & 59.2 & 5.8 & 3.2 & 2.7 & 23.8 & 94.6 & 81.8 \\
\hline FIN & 38.1 & 5.7 & 1.8 & 3.0 & 16.0 & 64.7 & 73.1 \\
\hline FRA & 36.1 & 12.1 & 3.0 & 4.1 & 14.1 & 69.4 & 63.0 \\
\hline DEU & 27.6 & 8.5 & 2.8 & 3.2 & 15.0 & 57.1 & 42.1 \\
\hline GRC & 49.2 & 4.0 & 2.1 & 2.8 & 19.8 & 77.8 & 70.3 \\
\hline HUN & 52.3 & 3.8 & 2.1 & 6.3 & 16.6 & 81.0 & 61.2 \\
\hline ISL & 34.5 & 9.4 & 2.5 & 2.0 & 27.3 & 75.5 & 66.5 \\
\hline IRL & 24.8 & 15.1 & 1.2 & 2.8 & 7.4 & 51.3 & 55.1 \\
\hline ISR & 24.3 & 11.1 & 7.0 & 5.6 & 19.5 & 67.6 & 78.2 \\
\hline ITA & 33.1 & 7.2 & 2.5 & 2.1 & 16.8 & 61.6 & 57.6 \\
\hline JPN & 11.3 & 6.1 & 3.9 & 4.1 & 9.0 & 34.4 & 20.7 \\
\hline KOR & 10.6 & 8.7 & 6.5 & 8.9 & 16.3 & 51.0 & 46.7 \\
\hline LVA & 50.4 & 3.0 & 2.1 & 1.6 & 25.3 & 82.4 & 81.5 \\
\hline LTU & 55.0 & 3.5 & 2.5 & 2.7 & 21.5 & 85.1 & 87.4 \\
\hline LUX & 63.5 & 6.8 & 1.7 & 2.4 & 10.7 & 85.1 & 84.7 \\
\hline MEX & 9.9 & 27.2 & 4.7 & 2.9 & 6.9 & 51.5 & 39.1 \\
\hline NLD & 32.1 & 11.1 & 2.5 & 4.6 & 14.0 & 64.2 & 58.5 \\
\hline NZL & 19.9 & 11.0 & 8.5 & 9.1 & 21.8 & 70.2 & 71.1 \\
\hline NOR & 22.6 & 4.7 & 1.5 & 2.2 & 6.4 & 37.4 & 37.2 \\
\hline POL & 50.3 & 5.9 & 3.5 & 3.0 & 15.5 & 78.2 & 68.8 \\
\hline PRT & 57.0 & 4.1 & 2.3 & 2.5 & 15.6 & 81.5 & 75.2 \\
\hline SVK & 55.6 & 5.7 & 2.9 & 4.7 & 26.2 & 95.1 & 90.4 \\
\hline SVN & 36.7 & 5.1 & 4.0 & 2.2 & 20.0 & 68.0 & 64.3 \\
\hline ESP & 35.0 & 12.9 & 3.3 & 2.5 & 14.6 & 68.2 & 57.0 \\
\hline SWE & 37.1 & 4.9 & 1.4 & 1.4 & 10.1 & 54.9 & 61.6 \\
\hline $\mathrm{CHE}$ & 49.5 & 11.2 & 3.5 & 3.7 & 7.5 & 75.5 & 75.5 \\
\hline TUR & 24.0 & 5.7 & 6.1 & 5.8 & 19.1 & 60.8 & 58.0 \\
\hline GBR & 36.1 & 9.1 & 2.9 & 2.8 & 15.7 & 66.5 & 59.1 \\
\hline USA & 11.7 & 3.3 & 3.0 & 3.0 & 7.8 & 28.9 & 29.1 \\
\hline
\end{tabular}

Continue ... 
Table B.20. continued

\begin{tabular}{|c|c|c|c|c|c|c|c|}
\hline \multirow[b]{2}{*}{ Country } & \multicolumn{6}{|c|}{2015} & \multirow[b]{2}{*}{2005} \\
\hline & EU28 & N. Am. & $\mathrm{CHN}$ & $\begin{array}{c}\text { Other } \\
\text { E\&SE Asia }\end{array}$ & ROW & Total & \\
\hline ARG & 9.0 & 7.9 & 4.0 & 1.7 & 10.5 & 33.1 & 41.2 \\
\hline BRA & 11.5 & 9.1 & 4.0 & 2.2 & 11.5 & 38.3 & 33.0 \\
\hline BRN & 6.3 & 5.2 & 3.1 & 26.4 & 8.1 & 49.3 & 72.5 \\
\hline BGR & 55.7 & 3.3 & 5.2 & 2.0 & 23.0 & 89.1 & 70.4 \\
\hline KHM & 7.5 & 3.6 & 15.9 & 29.8 & 14.4 & 71.3 & 80.6 \\
\hline $\mathrm{CHN}$ & 5.0 & 3.2 & 0.0 & 5.2 & 8.1 & 21.5 & 28.0 \\
\hline COL & 14.0 & 20.9 & 6.8 & 3.3 & 15.7 & 60.7 & 48.7 \\
\hline CRI & 15.5 & 21.4 & 4.8 & 2.8 & 33.2 & 77.7 & 86.8 \\
\hline HRV & 35.3 & 2.5 & 1.6 & 2.7 & 14.2 & 56.3 & 53.8 \\
\hline CYP & 46.8 & 3.1 & 5.1 & 3.7 & 18.1 & 76.8 & 76.6 \\
\hline IND & 6.0 & 4.2 & 9.8 & 7.3 & 14.8 & 42.1 & 36.9 \\
\hline IDN & 6.0 & 4.3 & 8.9 & 14.2 & 11.6 & 44.9 & 53.6 \\
\hline HKG & 12.0 & 6.9 & 12.3 & 15.3 & 12.1 & 58.6 & 54.2 \\
\hline KAZ & 28.6 & 6.6 & 7.0 & 3.4 & 31.4 & 77.0 & 88.4 \\
\hline MYS & 14.8 & 7.8 & 9.4 & 17.9 & 16.7 & 66.6 & 71.2 \\
\hline MLT & 37.6 & 5.3 & 6.8 & 3.7 & 25.2 & 78.5 & 69.9 \\
\hline MAR & 27.9 & 4.8 & 3.6 & 2.2 & 21.1 & 59.6 & 64.4 \\
\hline PER & 9.0 & 16.1 & 8.9 & 4.7 & 21.8 & 60.5 & 55.1 \\
\hline PHL & 9.2 & 7.0 & 10.2 & 22.1 & 14.4 & 63.0 & 51.6 \\
\hline ROU & 54.0 & 3.9 & 2.3 & 2.0 & 18.2 & 80.4 & 76.4 \\
\hline RUS & 29.2 & 5.9 & 4.1 & 2.7 & 15.8 & 57.6 & 67.7 \\
\hline SAU & 25.0 & 10.0 & 3.3 & 3.7 & 17.6 & 59.5 & 75.5 \\
\hline SGP & 10.3 & 8.6 & 3.3 & 14.4 & 17.9 & 54.5 & 47.4 \\
\hline ZAF & 24.2 & 9.8 & 6.4 & 3.6 & 25.2 & 69.2 & 55.4 \\
\hline TWN & 13.8 & 10.8 & 8.1 & 16.5 & 22.5 & 71.6 & 71.5 \\
\hline THA & 13.3 & 8.1 & 10.8 & 15.0 & 18.8 & 66.1 & 62.6 \\
\hline TUN & 35.7 & 5.1 & 3.6 & 3.0 & 23.2 & 70.6 & 71.3 \\
\hline VNM & 15.7 & 6.3 & 15.1 & 21.2 & 21.0 & 79.4 & 79.7 \\
\hline ROW & 20.2 & 7.7 & 5.3 & 5.2 & 14.3 & 52.7 & 49.2 \\
\hline
\end{tabular}

Note by Turkey: The information in this document with reference to "Cyprus" relates to the southern part of the Island. There is no single authority representing both Turkish and Greek Cypriot people on the Island. Turkey recognises the Turkish Republic of Northern Cyprus (TRNC). Until a lasting and equitable solution is found within the context of the United Nations, Turkey shall preserve its position concerning the "Cyprus issue".

Note by all the European Union Member States of the OECD and the European Union: The Republic of Cyprus is recognised by all members of the United Nations with the exception of Turkey. The information in this document relates to the area under the effective control of the Government of the Republic of Cyprus.

Source: OECD, Trade in Value Added (TiVA) database, http://oe.cd/tiva, 2018, Origin of value added in final demand 
Table B.21. Global demand for Computer, electronic and optical products, by country or region of final demand and origin of value added, percentage shares of total, 2005 and 2015

(Figure 4.9)

\begin{tabular}{lrrrr}
\hline \multirow{2}{*}{ Country or Region } & \multicolumn{2}{c}{ Final demand } & \multicolumn{2}{c}{ Value added } \\
\cline { 2 - 5 } & \multicolumn{1}{c}{2005} & \multicolumn{1}{c}{2015} & \multicolumn{1}{c}{2005} & \multicolumn{1}{c}{2015} \\
\hline North America & 37.3 & 20.9 & 28.7 & 17.1 \\
EU28 & 22.7 & 18.1 & 20.3 & 15.0 \\
Japan & 12.6 & 7.9 & 15.3 & 7.8 \\
Korea & 2.3 & 2.3 & 5.1 & 5.5 \\
China & 6.3 & 20.4 & 10.4 & 28.0 \\
Other E\&SE Asia & 4.9 & 7.6 & 10.0 & 12.4 \\
Brazil & 2.2 & 2.3 & 1.5 & 1.3 \\
India & 0.8 & 1.7 & 0.6 & 0.9 \\
Rest of the world & 10.9 & 18.9 & 8.2 & 11.9 \\
\hline
\end{tabular}

Source: OECD, Trade in Value Added database, http://oe.cd/tiva, 2018, Origin of value added in final demand.

Table B.22. Regional demand for Computer, electronic and optical products, by economy or region of value added origin, percentage shares of total, 2005 and 2015

(Figure 4.10)

\begin{tabular}{|c|c|c|c|c|c|c|}
\hline \multirow{2}{*}{ Region } & \multicolumn{2}{|c|}{ North America } & \multicolumn{2}{|c|}{ European Union } & \multicolumn{2}{|c|}{ East and Southeast Asia } \\
\hline & 2005 & 2015 & 2005 & 2015 & 2005 & 2015 \\
\hline Intra-regional & 61.9 & 55.3 & 60.3 & 51.0 & 82.1 & 83.2 \\
\hline North America & 0.0 & 0.0 & 9.0 & 8.4 & 7.7 & 5.9 \\
\hline European Union & 6.2 & 5.2 & 0.0 & 0.0 & 5.6 & 5.2 \\
\hline East and Southeast Asia & 27.6 & 35.3 & 23.0 & 31.3 & 0.0 & 0.0 \\
\hline Rest of the World & 4.3 & 4.3 & 7.8 & 9.3 & 4.6 & 5.7 \\
\hline \multicolumn{7}{|c|}{ Intra-regional: East and Southeast Asia } \\
\hline Country or Region & 2005 & 2015 & & & & \\
\hline Japan & 51.0 & 19.0 & & & & \\
\hline Korea & 10.9 & 10.8 & & & & \\
\hline China & 18.2 & 45.5 & & & & \\
\hline Chinese Taipei & 9.6 & 10.2 & & & & \\
\hline Other E\&SE Asia & 10.3 & 14.5 & & & & \\
\hline \multicolumn{7}{|l|}{ Intra-regional: Europe } \\
\hline Country or Region & 2005 & 2015 & & & & \\
\hline France & 10.2 & 10.0 & & & & \\
\hline Germany & 32.0 & 30.4 & & & & \\
\hline Italy & 8.1 & 8.5 & & & & \\
\hline United Kingdom & 10.5 & 9.7 & & & & \\
\hline EU13 & 6.8 & 10.8 & & & & \\
\hline Other EU28 & 32.5 & 30.6 & & & & \\
\hline
\end{tabular}

Source: OECD, Trade in Value Added database, http://oe.cd/tiva, 2018, Origin of value added in final demand. 
Table B.23. Foreign value added embodied in domestic demand for Computer, electronic and optical products, by source region, 2015, as a percentage of total domestic demand (Figure 4.11)

\begin{tabular}{|c|c|c|c|c|c|c|c|}
\hline \multirow[b]{2}{*}{ Country } & \multicolumn{6}{|c|}{2015} & \multirow[b]{2}{*}{2005} \\
\hline & EU28 & N. Am. & $\mathrm{CHN}$ & $\begin{array}{c}\text { Other } \\
\text { E\&SE Asia }\end{array}$ & ROW & Total & \\
\hline AUS & 10.0 & 11.4 & 38.4 & 21.1 & 7.3 & 88.3 & 84.0 \\
\hline AUT & 32.9 & 5.7 & 18.3 & 11.5 & 10.9 & 79.3 & 66.4 \\
\hline BEL & 39.6 & 11.4 & 11.9 & 10.2 & 9.5 & 82.5 & 85.6 \\
\hline CAN & 6.7 & 22.0 & 28.1 & 15.0 & 5.3 & 77.1 & 83.4 \\
\hline $\mathrm{CHL}$ & 7.8 & 16.9 & 39.8 & 16.0 & 9.0 & 89.5 & 89.5 \\
\hline CZE & 22.7 & 5.8 & 33.2 & 16.9 & 6.6 & 85.2 & 88.3 \\
\hline DNK & 41.7 & 7.5 & 10.3 & 7.6 & 7.2 & 74.2 & 78.3 \\
\hline EST & 43.9 & 7.3 & 22.1 & 11.7 & 9.4 & 94.4 & 97.6 \\
\hline FIN & 21.6 & 6.8 & 14.8 & 9.9 & 6.7 & 59.7 & 50.5 \\
\hline FRA & 21.2 & 8.6 & 23.4 & 14.0 & 14.4 & 81.7 & 82.4 \\
\hline DEU & 15.8 & 7.2 & 19.8 & 14.6 & 8.3 & 65.7 & 36.2 \\
\hline GRC & 33.1 & 5.2 & 19.3 & 7.9 & 9.5 & 75.0 & 88.4 \\
\hline HUN & 39.8 & 6.6 & 20.3 & 16.6 & 8.4 & 91.7 & 94.7 \\
\hline ISL & 26.6 & 13.3 & 31.3 & 18.5 & 8.1 & 97.8 & 97.3 \\
\hline IRL & 21.6 & 12.3 & 6.4 & 6.7 & 4.5 & 51.4 & 71.7 \\
\hline ISR & 23.9 & 19.1 & 7.8 & 10.6 & 7.0 & 68.5 & 75.2 \\
\hline ITA & 33.4 & 6.4 & 13.7 & 7.6 & 9.6 & 70.8 & 74.6 \\
\hline JPN & 4.4 & 5.3 & 18.2 & 11.2 & 5.2 & 44.4 & 27.0 \\
\hline KOR & 6.0 & 7.0 & 20.0 & 17.1 & 6.2 & 56.3 & 54.9 \\
\hline LVA & 45.3 & 4.1 & 13.1 & 8.5 & 8.1 & 79.1 & 91.7 \\
\hline LTU & 58.6 & 6.3 & 11.7 & 6.2 & 8.7 & 91.5 & 90.0 \\
\hline LUX & 33.7 & 10.0 & 8.7 & 8.3 & 8.0 & 68.7 & 93.2 \\
\hline MEX & 5.9 & 13.7 & 33.0 & 24.5 & 5.2 & 82.2 & 48.3 \\
\hline NLD & 26.5 & 17.2 & 12.6 & 12.8 & 8.1 & 77.4 & 56.0 \\
\hline NZL & 8.6 & 9.1 & 32.2 & 18.9 & 12.1 & 80.9 & 82.6 \\
\hline NOR & 22.8 & 7.9 & 24.0 & 12.9 & 6.6 & 74.1 & 80.4 \\
\hline POL & 24.3 & 6.2 & 32.9 & 19.7 & 8.7 & 91.8 & 81.9 \\
\hline PRT & 61.9 & 5.6 & 10.2 & 7.5 & 6.7 & 91.9 & 87.1 \\
\hline SVK & 22.0 & 4.5 & 26.2 & 22.5 & 18.1 & 93.3 & 93.5 \\
\hline SVN & 28.0 & 5.7 & 23.4 & 16.0 & 8.7 & 81.8 & 89.0 \\
\hline ESP & 34.7 & 7.7 & 22.7 & 11.9 & 10.6 & 87.6 & 81.6 \\
\hline SWE & 44.3 & 7.5 & 8.3 & 7.4 & 8.8 & 76.4 & 61.8 \\
\hline $\mathrm{CHE}$ & 24.6 & 6.1 & 13.0 & 7.8 & 5.5 & 57.0 & 54.9 \\
\hline TUR & 16.4 & 6.2 & 32.7 & 20.0 & 7.8 & 83.1 & 89.1 \\
\hline GBR & 27.8 & 10.3 & 20.9 & 12.2 & 8.6 & 79.8 & 81.7 \\
\hline USA & 4.9 & 4.4 & 19.5 & 12.2 & 4.1 & 45.0 & 41.7 \\
\hline
\end{tabular}


Table B.23. continued

\begin{tabular}{|c|c|c|c|c|c|c|c|}
\hline \multirow[b]{2}{*}{ Country } & \multicolumn{6}{|c|}{2015} & \multirow[b]{2}{*}{2005} \\
\hline & EU28 & N. Am. & $\mathrm{CHN}$ & $\begin{array}{c}\text { Other } \\
\text { E\&SE Asia }\end{array}$ & ROW & Total & \\
\hline ARG & 6.5 & 6.7 & 24.6 & 11.2 & 6.4 & 55.5 & 70.7 \\
\hline BRA & 8.0 & 8.4 & 19.2 & 14.1 & 4.8 & 54.6 & 51.1 \\
\hline BRN & 10.7 & 8.6 & 13.9 & 20.2 & 9.1 & 62.5 & 66.8 \\
\hline BGR & 56.2 & 6.7 & 11.0 & 10.1 & 11.6 & 95.6 & 87.0 \\
\hline $\mathrm{KHM}$ & 3.7 & 3.2 & 18.8 & 22.7 & 7.3 & 55.8 & 76.0 \\
\hline $\mathrm{CHN}$ & 4.9 & 5.3 & 0.0 & 29.5 & 5.3 & 45.1 & 60.0 \\
\hline COL & 8.9 & 18.3 & 45.7 & 17.7 & 8.3 & 99.0 & 99.4 \\
\hline CRI & 7.3 & 34.3 & 25.9 & 15.7 & 12.5 & 95.6 & 87.4 \\
\hline HRV & 50.6 & 4.9 & 10.6 & 6.2 & 8.4 & 80.8 & 81.6 \\
\hline CYP & 48.3 & 6.4 & 9.8 & 7.8 & 15.0 & 87.2 & 95.9 \\
\hline IND & 7.6 & 6.5 & 28.6 & 17.9 & 8.3 & 68.9 & 55.9 \\
\hline IDN & 5.0 & 3.8 & 16.9 & 16.4 & 5.5 & 47.6 & 56.5 \\
\hline HKG & 6.9 & 9.1 & 17.3 & 15.9 & 9.9 & 59.1 & 43.4 \\
\hline $\mathrm{KAZ}$ & 14.4 & 6.6 & 26.6 & 13.2 & 35.1 & 96.0 & 97.3 \\
\hline MYS & 8.6 & 11.1 & 19.7 & 31.0 & 7.3 & 77.6 & 95.3 \\
\hline MLT & 46.7 & 7.2 & 8.1 & 18.7 & 11.2 & 91.9 & 97.9 \\
\hline MAR & 28.2 & 6.3 & 24.8 & 14.4 & 9.7 & 83.4 & 95.0 \\
\hline PER & 7.6 & 14.5 & 44.7 & 19.4 & 7.4 & 93.5 & 90.2 \\
\hline PHL & 9.0 & 13.9 & 13.5 & 35.7 & 5.8 & 77.9 & 88.5 \\
\hline ROU & 49.5 & 5.2 & 14.3 & 8.8 & 8.2 & 86.0 & 79.4 \\
\hline RUS & 10.9 & 4.8 & 24.7 & 11.6 & 6.5 & 58.5 & 64.7 \\
\hline SAU & 14.4 & 12.6 & 38.3 & 18.9 & 14.2 & 98.5 & 93.7 \\
\hline SGP & 9.6 & 10.2 & 3.9 & 15.1 & 9.9 & 48.7 & 47.7 \\
\hline ZAF & 14.4 & 8.5 & 41.3 & 18.3 & 9.9 & 92.4 & 89.7 \\
\hline TWN & 4.8 & 6.1 & 16.4 & 19.1 & 6.6 & 53.0 & 62.1 \\
\hline THA & 6.6 & 7.9 & 26.1 & 30.7 & 8.3 & 79.6 & 86.3 \\
\hline TUN & 25.1 & 3.6 & 20.1 & 10.2 & 7.0 & 66.0 & 67.5 \\
\hline VNM & 5.8 & 7.0 & 31.1 & 38.7 & 10.4 & 92.8 & 75.7 \\
\hline ROW & 10.7 & 7.0 & 20.9 & 13.8 & 7.5 & 59.8 & 61.5 \\
\hline
\end{tabular}

Note by Turkey: The information in this document with reference to "Cyprus" relates to the southern part of the Island. There is no single authority representing both Turkish and Greek Cypriot people on the Island. Turkey recognises the Turkish Republic of Northern Cyprus (TRNC). Until a lasting and equitable solution is found within the context of the United Nations, Turkey shall preserve its position concerning the "Cyprus issue".

Note by all the European Union Member States of the OECD and the European Union: The Republic of Cyprus is recognised by all members of the United Nations with the exception of Turkey. The information in this document relates to the area under the effective control of the Government of the Republic of Cyprus.

Source: OECD, Trade in Value Added (TiVA) database, http://oe.cd/tiva, 2018, Origin of value added in final demand. 
Table B.24. Global demand for Motor vehicles, by country or region of final demand and origin of value added, percentage shares of total, 2005 and 2015 (Figure 4.12)

\begin{tabular}{lrrrr}
\hline \multirow{2}{*}{ Country or Region } & \multicolumn{2}{c}{ Final demand } & \multicolumn{2}{c}{ Value added } \\
\cline { 2 - 5 } & \multicolumn{1}{c}{2005} & 2015 & 2005 & 2015 \\
\hline North America & 32.0 & 35.3 & 24.2 & 25.8 \\
EU28 & 33.4 & 17.8 & 36.1 & 24.0 \\
Japan & 7.9 & 2.6 & 14.4 & 7.5 \\
Korea & 1.8 & 1.5 & 3.2 & 3.6 \\
China & 5.6 & 20.7 & 5.9 & 20.6 \\
Other E\&SE Asia & 3.0 & 3.7 & 2.9 & 4.1 \\
Brazil & 2.2 & 2.1 & 2.5 & 2.0 \\
India & 1.8 & 3.0 & 1.6 & 2.6 \\
Rest of the world & 12.3 & 13.3 & 9.2 & 9.9 \\
\hline
\end{tabular}

Source: OECD, Trade in Value Added database, http://oe.cd/tiva, 2018, Origin of value added in final demand.

Table B.25. Regional demand for Motor vehicles by economy or region of value added origin, percentage shares of total, 2005 and 2015 (Figure 4.13)

\begin{tabular}{|c|c|c|c|c|c|c|}
\hline \multirow{2}{*}{ Region } & \multicolumn{2}{|c|}{ North America } & \multicolumn{2}{|c|}{ European Union } & \multicolumn{2}{|c|}{ East and Southeast Asia } \\
\hline & 2005 & 2015 & 2005 & 2015 & 2005 & 2015 \\
\hline Intra-regional & 67.6 & 64.4 & 83.2 & 80.8 & 86.4 & 82.6 \\
\hline North America & 0.0 & 0.0 & 3.0 & 3.5 & 2.8 & 4.0 \\
\hline European Union & 11.4 & 11.3 & 0.0 & 0.0 & 5.7 & 8.3 \\
\hline East and Southeast Asia & 16.6 & 19.7 & 7.1 & 8.0 & 0.0 & 0.0 \\
\hline Rest of the World & 4.4 & 4.6 & 6.7 & 7.7 & 5.1 & 5.1 \\
\hline \multicolumn{7}{|c|}{ Intra-regional: East and Southeast Asia } \\
\hline Country or Region & 2005 & 2015 & & & & \\
\hline Japan & 51.5 & 14.1 & & & & \\
\hline Korea & 9.6 & 6.2 & & & & \\
\hline China & 27.4 & 68.9 & & & & \\
\hline Chinese Taipei & 2.5 & 1.7 & & & & \\
\hline Other E\&SE Asia & 9.0 & 9.0 & & & & \\
\hline \multicolumn{7}{|l|}{ Intra-regional: Europe } \\
\hline Country or Region & 2005 & 2015 & & & & \\
\hline France & 15.1 & 10.5 & & & & \\
\hline Germany & 37.5 & 40.9 & & & & \\
\hline Italy & 9.1 & 7.1 & & & & \\
\hline United Kingdom & 9.1 & 8.6 & & & & \\
\hline EU13 & 8.2 & 12.9 & & & & \\
\hline Other EU28 & 21.0 & 20.1 & & & & \\
\hline
\end{tabular}

Source: OECD, Trade in Value Added database, http://oe.cd/tiva, 2018, Origin of value added in final demand. 
Table B.26. Foreign value added embodied in domestic demand for Motor vehicles, by source region, as a percentage of total domestic demand (Figure 4.14)

\begin{tabular}{|c|c|c|c|c|c|c|c|}
\hline \multirow[b]{2}{*}{ Country } & \multicolumn{6}{|c|}{2015} & \multirow[b]{2}{*}{2005} \\
\hline & EU28 & N. Am. & $\mathrm{CHN}$ & $\begin{array}{c}\text { Other } \\
\text { E\&SE Asia }\end{array}$ & ROW & Total & \\
\hline AUS & 20.1 & 10.7 & 7.6 & 35.7 & 7.1 & 81.2 & 74.0 \\
\hline AUT & 61.5 & 4.0 & 2.6 & 5.7 & 7.4 & 81.2 & 80.1 \\
\hline BEL & 63.5 & 5.8 & 3.3 & 10.4 & 9.4 & 92.3 & 91.0 \\
\hline CAN & 9.3 & 46.6 & 7.1 & 10.1 & 4.3 & 77.5 & 72.5 \\
\hline $\mathrm{CHL}$ & 17.2 & 14.7 & 12.8 & 29.5 & 17.7 & 92.0 & 93.8 \\
\hline CZE & 53.9 & 3.0 & 4.0 & 7.6 & 9.1 & 77.7 & 67.0 \\
\hline DNK & 70.4 & 2.7 & 4.6 & 4.6 & 7.7 & 90.0 & 88.2 \\
\hline EST & 54.2 & 4.1 & 4.5 & 10.5 & 9.9 & 83.2 & 94.2 \\
\hline FIN & 69.9 & 4.1 & 3.3 & 5.5 & 8.3 & 91.1 & 87.3 \\
\hline FRA & 48.9 & 2.9 & 3.2 & 5.0 & 9.5 & 69.5 & 63.7 \\
\hline DEU & 23.4 & 3.7 & 2.6 & 3.1 & 5.9 & 38.7 & 40.7 \\
\hline GRC & 67.1 & 2.8 & 4.2 & 6.4 & 11.2 & 91.7 & 94.8 \\
\hline HUN & 62.0 & 2.8 & 3.3 & 4.9 & 6.8 & 79.8 & 82.3 \\
\hline ISL & 60.1 & 6.8 & 4.1 & 18.4 & 9.2 & 98.5 & 99.0 \\
\hline IRL & 57.3 & 4.8 & 3.5 & 11.1 & 11.5 & 88.2 & 86.6 \\
\hline ISR & 44.9 & 7.8 & 5.4 & 18.4 & 11.7 & 88.1 & 87.7 \\
\hline ITA & 44.2 & 3.3 & 3.5 & 3.8 & 9.4 & 64.1 & 65.8 \\
\hline JPN & 5.8 & 2.3 & 4.7 & 4.1 & 3.5 & 20.4 & 11.1 \\
\hline KOR & 14.2 & 5.0 & 8.7 & 6.7 & 5.7 & 40.4 & 33.5 \\
\hline LVA & 72.5 & 2.3 & 2.8 & 2.6 & 7.4 & 87.7 & 95.6 \\
\hline LTU & 71.9 & 4.2 & 4.1 & 2.7 & 7.7 & 90.5 & 85.7 \\
\hline LUX & 54.4 & 4.6 & 1.8 & 3.8 & 7.5 & 71.9 & 82.0 \\
\hline MEX & 8.2 & 24.6 & 6.1 & 8.4 & 5.5 & 52.8 & 45.2 \\
\hline NLD & 59.7 & 4.8 & 3.4 & 4.7 & 6.4 & 78.9 & 83.8 \\
\hline NZL & 22.0 & 8.6 & 6.6 & 40.5 & 9.8 & 87.6 & 90.6 \\
\hline NOR & 67.0 & 7.7 & 3.8 & 10.9 & 6.0 & 95.5 & 88.2 \\
\hline POL & 48.4 & 2.9 & 4.3 & 4.7 & 8.3 & 68.6 & 63.2 \\
\hline PRT & 73.2 & 2.3 & 2.6 & 3.9 & 6.9 & 89.0 & 79.1 \\
\hline SVK & 55.1 & 2.7 & 3.8 & 11.0 & 7.7 & 80.4 & 86.7 \\
\hline SVN & 55.2 & 3.0 & 3.6 & 8.4 & 9.9 & 80.1 & 85.6 \\
\hline ESP & 48.2 & 2.9 & 3.4 & 5.0 & 8.1 & 67.6 & 70.5 \\
\hline SWE & 41.7 & 2.4 & 2.2 & 3.4 & 5.5 & 55.3 & 65.7 \\
\hline $\mathrm{CHE}$ & 75.3 & 6.4 & 2.8 & 6.6 & 5.8 & 97.0 & 97.5 \\
\hline TUR & 41.1 & 3.5 & 4.5 & 5.8 & 9.0 & 63.9 & 61.6 \\
\hline GBR & 52.6 & 3.9 & 3.7 & 6.5 & 7.8 & 74.6 & 69.0 \\
\hline USA & 11.7 & 10.7 & 7.4 & 12.9 & 4.6 & 47.2 & 44.5 \\
\hline
\end{tabular}

Continue ... 
Table B.26. continued

\begin{tabular}{|c|c|c|c|c|c|c|c|}
\hline \multirow[b]{2}{*}{ Country } & \multicolumn{6}{|c|}{2015} & \multirow[b]{2}{*}{2005} \\
\hline & EU28 & N. Am. & $\mathrm{CHN}$ & $\begin{array}{c}\text { Other } \\
\text { E\&SE Asia }\end{array}$ & ROW & Total & \\
\hline ARG & 6.6 & 4.5 & 3.4 & 3.5 & 24.1 & 42.1 & 54.1 \\
\hline BRA & 8.8 & 5.6 & 3.8 & 5.2 & 11.0 & 34.4 & 22.0 \\
\hline BRN & 18.2 & 4.6 & 7.3 & 34.1 & 6.8 & 71.0 & 79.9 \\
\hline BGR & 65.7 & 2.4 & 3.5 & 3.5 & 12.7 & 87.7 & 94.9 \\
\hline KHM & 5.8 & 9.6 & 9.8 & 38.2 & 4.5 & 67.9 & 65.1 \\
\hline $\mathrm{CHN}$ & 8.0 & 4.1 & 0.0 & 7.6 & 4.8 & 24.6 & 28.4 \\
\hline COL & 10.0 & 16.0 & 8.0 & 11.3 & 22.1 & 67.4 & 53.6 \\
\hline CRI & 14.5 & 24.9 & 10.1 & 34.3 & 12.6 & 96.5 & 91.7 \\
\hline HRV & 77.9 & 2.5 & 2.7 & 3.0 & 7.6 & 93.6 & 87.5 \\
\hline CYP & 66.8 & 3.0 & 3.4 & 16.1 & 9.2 & 98.4 & 97.3 \\
\hline IND & 6.4 & 3.8 & 5.4 & 7.0 & 10.7 & 33.3 & 28.7 \\
\hline IDN & 3.0 & 1.5 & 3.9 & 14.0 & 3.4 & 25.9 & 33.4 \\
\hline HKG & 12.3 & 9.0 & 12.0 & 15.4 & 9.3 & 57.9 & 37.7 \\
\hline $\mathrm{KAZ}$ & 17.3 & 4.0 & 10.3 & 10.3 & 43.5 & 85.5 & 96.6 \\
\hline MYS & 11.9 & 4.4 & 13.9 & 29.6 & 9.3 & 69.1 & 73.5 \\
\hline MLT & 46.3 & 3.5 & 2.8 & 12.9 & 17.5 & 83.1 & 93.7 \\
\hline MAR & 63.0 & 5.9 & 4.4 & 9.0 & 12.2 & 94.5 & 82.1 \\
\hline PER & 10.5 & 12.0 & 13.4 & 25.0 & 15.9 & 76.8 & 63.8 \\
\hline PHL & 5.2 & 3.6 & 9.0 & 38.1 & 6.1 & 62.0 & 54.4 \\
\hline ROU & 42.3 & 2.0 & 2.5 & 2.2 & 8.3 & 57.2 & 64.3 \\
\hline RUS & 20.9 & 4.9 & 7.9 & 13.1 & 8.3 & 55.1 & 61.3 \\
\hline SAU & 17.5 & 17.8 & 8.4 & 43.1 & 8.9 & 95.6 & 94.6 \\
\hline SGP & 34.0 & 10.0 & 7.6 & 30.7 & 7.8 & 90.1 & 94.5 \\
\hline ZAF & 25.3 & 6.0 & 7.8 & 13.3 & 15.4 & 67.9 & 48.1 \\
\hline TWN & 17.3 & 5.0 & 8.9 & 21.8 & 9.5 & 62.5 & 61.2 \\
\hline THA & 8.1 & 4.3 & 12.3 & 29.7 & 8.5 & 62.8 & 62.8 \\
\hline TUN & 40.8 & 2.5 & 5.2 & 9.3 & 12.0 & 69.8 & 71.5 \\
\hline VNM & 6.0 & 3.4 & 21.5 & 25.1 & 7.9 & 63.8 & 56.2 \\
\hline ROW & 18.5 & 7.3 & 7.4 & 14.1 & 7.9 & 55.2 & 62.7 \\
\hline
\end{tabular}

Note by Turkey: The information in this document with reference to "Cyprus" relates to the southern part of the Island. There is no single authority representing both Turkish and Greek Cypriot people on the Island. Turkey recognises the Turkish Republic of Northern Cyprus (TRNC). Until a lasting and equitable solution is found within the context of the United Nations, Turkey shall preserve its position concerning the "Cyprus issue". Note by all the European Union Member States of the OECD and the European Union: The Republic of Cyprus is recognised by all members of the United Nations with the exception of Turkey. The information in this document relates to the area under the effective control of the Government of the Republic of Cyprus.

Source: OECD, Trade in Value Added (TiVA) database, http://oe.cd/tiva, 2018, Origin of value added in final demand. 
Table B.27. Services value added embodied in manufactured exports, by domestic and foreign origin, 2015, as a percentage of total manufacturing exports (Figure 5.1)

\begin{tabular}{|c|c|c|c|c|c|}
\hline \multirow[b]{2}{*}{ Country } & \multicolumn{4}{|c|}{2015} & \multirow[b]{2}{*}{2005} \\
\hline & DVA & $\begin{array}{c}\text { FVA } \\
\text { Intra-region }\end{array}$ & $\begin{array}{c}\mathrm{FVA} \\
\text { extra-region }\end{array}$ & Total & \\
\hline AUS & 30.4 & 1.4 & 5.4 & 37.3 & 28.6 \\
\hline AUT & 17.2 & 10.1 & 5.0 & 32.3 & 30.6 \\
\hline BEL & 17.0 & 12.7 & 8.1 & 37.8 & 34.7 \\
\hline CAN & 17.8 & 7.6 & 5.4 & 30.8 & 30.7 \\
\hline $\mathrm{CHL}$ & 22.2 & 2.5 & 5.9 & 30.6 & 26.4 \\
\hline CZE & 13.0 & 12.2 & 6.7 & 31.9 & 31.4 \\
\hline DNK & 20.4 & 8.3 & 5.2 & 33.9 & 34.9 \\
\hline EST & 13.9 & 12.6 & 8.1 & 34.5 & 32.5 \\
\hline FIN & 15.1 & 8.4 & 6.3 & 29.7 & 27.8 \\
\hline FRA & 23.9 & 7.2 & 5.6 & 36.7 & 37.4 \\
\hline DEU & 18.7 & 6.1 & 5.1 & 29.8 & 33.0 \\
\hline GRC & 14.4 & 4.7 & 6.7 & 25.7 & 28.4 \\
\hline HUN & 8.4 & 14.6 & 7.1 & 30.1 & 34.5 \\
\hline ISL & 17.6 & 2.9 & 10.1 & 30.6 & 29.4 \\
\hline IRL & 11.0 & 12.5 & 13.2 & 36.7 & 40.5 \\
\hline ISR & 14.1 & 2.7 & 8.4 & 25.2 & 26.5 \\
\hline ITA & 25.1 & 6.4 & 5.2 & 36.7 & 38.6 \\
\hline JPN & 22.7 & 2.2 & 3.8 & 28.7 & 29.3 \\
\hline KOR & 12.7 & 5.6 & 7.0 & 25.3 & 24.8 \\
\hline LVA & 21.3 & 8.5 & 4.9 & 34.6 & 34.3 \\
\hline LTU & 12.3 & 7.7 & 8.9 & 28.9 & 26.6 \\
\hline LUX & 12.6 & 26.8 & 15.8 & 55.2 & 36.8 \\
\hline MEX & 17.2 & 8.4 & 10.1 & 35.7 & 38.2 \\
\hline NLD & 21.0 & 10.5 & 11.7 & 43.2 & 37.7 \\
\hline NZL & 26.4 & 2.6 & 5.2 & 34.2 & 32.0 \\
\hline NOR & 27.1 & 1.9 & 11.4 & 40.4 & 33.0 \\
\hline POL & 19.1 & 8.6 & 5.8 & 33.4 & 34.0 \\
\hline PRT & 18.4 & 10.8 & 4.5 & 33.6 & 33.0 \\
\hline SVK & 12.6 & 12.2 & 7.7 & 32.5 & 29.9 \\
\hline SVN & 12.7 & 11.3 & 5.6 & 29.6 & 29.4 \\
\hline ESP & 22.0 & 7.3 & 5.2 & 34.5 & 34.2 \\
\hline SWE & 20.0 & 7.5 & 5.1 & 32.6 & 32.8 \\
\hline $\mathrm{CHE}$ & 18.9 & 1.5 & 13.9 & 34.4 & 32.8 \\
\hline TUR & 24.7 & 2.5 & 6.0 & 33.2 & 32.1 \\
\hline GBR & 22.8 & 5.2 & 5.7 & 33.7 & 33.1 \\
\hline USA & 24.3 & 1.2 & 4.2 & 29.7 & 30.5 \\
\hline
\end{tabular}


Table B.27. continued

\begin{tabular}{|c|c|c|c|c|c|}
\hline \multirow[b]{2}{*}{ Country } & \multicolumn{4}{|c|}{2015} & \multirow[b]{2}{*}{2005} \\
\hline & DVA & $\begin{array}{c}\text { FVA } \\
\text { Intra-region }\end{array}$ & $\begin{array}{c}\text { FVA } \\
\text { extra-region }\end{array}$ & Total & \\
\hline ARG & 14.8 & 1.6 & 2.3 & 18.6 & 22.3 \\
\hline BRA & 29.9 & 1.5 & 5.8 & 37.1 & 28.5 \\
\hline BRN & 7.3 & 5.0 & 3.4 & 15.7 & 21.5 \\
\hline BGR & 14.1 & 10.7 & 8.6 & 33.4 & 26.7 \\
\hline KHM & 6.2 & 10.9 & 3.1 & 20.2 & 21.7 \\
\hline $\mathrm{CHN}$ & 23.0 & 2.6 & 4.1 & 29.7 & 24.2 \\
\hline COL & 19.8 & 1.9 & 6.9 & 28.5 & 25.4 \\
\hline CRI & 22.6 & 2.8 & 8.4 & 33.8 & 27.2 \\
\hline HRV & 15.7 & 9.1 & 3.6 & 28.4 & 28.3 \\
\hline CYP & 18.2 & 10.3 & 7.6 & 36.1 & 31.3 \\
\hline IND & 16.6 & 2.9 & 5.6 & 25.2 & 23.3 \\
\hline IDN & 16.6 & 3.6 & 3.2 & 23.4 & 24.9 \\
\hline HKG & 17.3 & 9.1 & 13.2 & 39.7 & 59.7 \\
\hline KAZ & 17.6 & 1.5 & 1.7 & 20.7 & 25.8 \\
\hline MYS & 10.0 & 9.4 & 8.6 & 28.0 & 29.9 \\
\hline MLT & 12.2 & 20.3 & 13.2 & 45.7 & 37.9 \\
\hline MAR & 7.4 & 3.3 & 11.0 & 21.7 & 21.2 \\
\hline PER & 18.4 & 1.8 & 4.5 & 24.6 & 24.5 \\
\hline PHL & 11.4 & 6.8 & 4.7 & 22.9 & 22.6 \\
\hline ROU & 15.0 & 8.9 & 4.1 & 28.0 & 27.7 \\
\hline RUS & 22.1 & 1.5 & 4.5 & 28.1 & 23.2 \\
\hline SAU & 8.5 & 1.9 & 4.4 & 14.8 & 13.6 \\
\hline SGP & 19.7 & 9.4 & 18.1 & 47.2 & 42.5 \\
\hline ZAF & 19.0 & 2.9 & 7.2 & 29.1 & 26.3 \\
\hline TWN & 13.6 & 6.6 & 5.9 & 26.1 & 30.0 \\
\hline THA & 12.9 & 7.7 & 6.6 & 27.2 & 29.6 \\
\hline TUN & 10.4 & 3.1 & 11.3 & 24.9 & 27.5 \\
\hline VNM & 7.0 & 11.4 & 6.4 & 24.8 & 22.8 \\
\hline ROW & 14.7 & 2.1 & 7.0 & 23.9 & 25.0 \\
\hline
\end{tabular}

Note by Turkey: The information in this document with reference to "Cyprus" relates to the southern part of the Island. There is no single authority representing both Turkish and Greek Cypriot people on the Island. Turkey recognises the Turkish Republic of Northern Cyprus (TRNC). Until a lasting and equitable solution is found within the context of the United Nations, Turkey shall preserve its position concerning the "Cyprus issue".

Note by all the European Union Member States of the OECD and the European Union: The Republic of Cyprus is recognised by all members of the United Nations with the exception of Turkey. The information in this document relates to the area under the effective control of the Government of the Republic of Cyprus.

Source: OECD, Trade in Value Added (TiVA) database, http://oe.cd/tiva, 2018, Origin of value added in gross exports 
Table B.28. Non-residents' expenditure by origin of value added, 2015 as a percentage of total gross exports (Figure 5.2)

\begin{tabular}{|c|c|c|c|c|c|}
\hline \multirow[b]{2}{*}{ Country } & \multicolumn{4}{|c|}{2015} & \multirow[b]{2}{*}{2005} \\
\hline & $\begin{array}{c}\text { Direct } \\
\text { domestic }\end{array}$ & $\begin{array}{c}\text { Indirect } \\
\text { domestic }\end{array}$ & Foreign & Total & \\
\hline AUS & 5.5 & 3.8 & 1.0 & 10.3 & 10.6 \\
\hline AUT & 4.9 & 1.7 & 1.1 & 7.7 & 8.8 \\
\hline BEL & 1.4 & 0.6 & 0.7 & 2.7 & 3.2 \\
\hline CAN & 2.2 & 1.0 & 0.4 & 3.6 & 3.5 \\
\hline $\mathrm{CHL}$ & 1.5 & 0.8 & 0.3 & 2.6 & 2.1 \\
\hline CZE & 1.9 & 0.9 & 0.8 & 3.5 & 4.7 \\
\hline DNK & 2.3 & 1.0 & 0.9 & 4.1 & 4.2 \\
\hline EST & 4.2 & 1.9 & 2.0 & 8.0 & 10.8 \\
\hline FIN & 1.5 & 0.8 & 0.5 & 2.7 & 2.3 \\
\hline FRA & 3.6 & 1.6 & 0.6 & 5.8 & 6.9 \\
\hline DEU & 1.4 & 0.6 & 0.3 & 2.3 & 2.7 \\
\hline GRC & 14.8 & 7.1 & 3.4 & 25.3 & 24.0 \\
\hline HUN & 2.2 & 1.1 & 1.2 & 4.4 & 5.3 \\
\hline ISL & 7.2 & 3.9 & 2.3 & 13.4 & 5.7 \\
\hline IRL & 0.7 & 0.2 & 0.3 & 1.1 & 2.4 \\
\hline ISR & 3.9 & 1.5 & 0.7 & 6.2 & 5.8 \\
\hline ITA & 4.1 & 1.9 & 0.7 & 6.7 & 7.2 \\
\hline JPN & 1.3 & 1.2 & 0.3 & 2.8 & 1.2 \\
\hline KOR & 0.9 & 0.6 & 0.3 & 1.8 & 1.0 \\
\hline LVA & 3.6 & 1.6 & 1.2 & 6.4 & 3.8 \\
\hline LTU & 2.2 & 0.6 & 0.6 & 3.4 & 6.5 \\
\hline LUX & 1.2 & 0.3 & 1.0 & 2.5 & 5.0 \\
\hline MEX & 2.8 & 1.0 & 0.3 & 4.1 & 4.8 \\
\hline NLD & 1.7 & 0.8 & 0.6 & 3.1 & 2.9 \\
\hline NZL & 9.5 & 5.0 & 1.6 & 16.2 & 16.7 \\
\hline NOR & 1.5 & 0.9 & 0.4 & 2.8 & 2.3 \\
\hline POL & 1.8 & 1.1 & 0.6 & 3.4 & 2.2 \\
\hline PRT & 8.1 & 3.3 & 1.9 & 13.3 & 12.4 \\
\hline SVK & 1.8 & 0.7 & 0.7 & 3.2 & 3.5 \\
\hline SVN & 4.4 & 1.9 & 1.6 & 7.8 & 8.1 \\
\hline ESP & 6.7 & 3.1 & 1.3 & 11.1 & 13.4 \\
\hline SWE & 3.0 & 1.6 & 0.8 & 5.3 & 3.4 \\
\hline $\mathrm{CHE}$ & 2.5 & 1.4 & 0.9 & 4.7 & 5.1 \\
\hline TUR & 9.2 & 5.3 & 1.3 & 15.8 & 19.4 \\
\hline GBR & 3.6 & 1.6 & 0.6 & 5.7 & 4.9 \\
\hline USA & 5.4 & 3.0 & 0.5 & 9.0 & 7.6 \\
\hline ARG & 1.2 & 0.6 & 0.1 & 1.9 & 1.5 \\
\hline BRA & 0.3 & 0.2 & 0.0 & 0.5 & 0.7 \\
\hline $\mathrm{CHN}$ & 0.1 & 0.1 & 0.0 & 0.2 & 0.4 \\
\hline CRI & 10.1 & 5.4 & 2.1 & 17.7 & 20.4 \\
\hline IND & 2.3 & 1.9 & 0.5 & 4.8 & 4.6 \\
\hline IDN & 1.9 & 1.3 & 0.3 & 3.6 & 2.2 \\
\hline RUS & 1.0 & 0.7 & 0.2 & 1.9 & 2.0 \\
\hline SAU & 1.9 & 0.7 & 0.4 & 3.1 & 1.7 \\
\hline ZAF & 3.6 & 2.5 & 1.2 & 7.3 & 9.8 \\
\hline
\end{tabular}

Source: Estimation based on OECD's Inter-Country Input-Output (ICIO) Database, 2018 
Table B.29. Jobs in the business sector sustained by foreign demand, by region of demand, 2015, as a percentage of total business sector employment (Figure 6.1)

\begin{tabular}{|c|c|c|c|c|c|c|c|}
\hline \multirow[b]{2}{*}{ Economy } & \multicolumn{6}{|c|}{2015} & \multirow[b]{2}{*}{2005} \\
\hline & EU28 & $\begin{array}{c}\text { North } \\
\text { America }\end{array}$ & China & $\begin{array}{c}\text { Other } \\
\text { E \& SE Asia }\end{array}$ & $\begin{array}{l}\text { Rest of } \\
\text { the world }\end{array}$ & Total & \\
\hline OECD & - & - & - & - & - & 38.3 & 34.0 \\
\hline EU28 & - & 4.7 & 2.0 & 2.1 & 9.7 & 18.6 & 13.4 \\
\hline AUS & 1.8 & 2.8 & 5.8 & 5.5 & 4.8 & 20.7 & 18.7 \\
\hline AUT & 23.5 & 4.7 & 2.2 & 1.9 & 10.4 & 42.7 & 40.1 \\
\hline BEL & 29.1 & 6.6 & 1.9 & 2.5 & 11.3 & 51.4 & 47.1 \\
\hline CAN & 2.6 & 16.0 & 1.9 & 1.6 & 3.5 & 25.5 & 30.6 \\
\hline $\mathrm{CHL}$ & 3.4 & 5.7 & 5.5 & 3.8 & 8.7 & 27.2 & 32.2 \\
\hline CZE & 32.1 & 4.4 & 2.2 & 1.6 & 11.3 & 51.6 & 44.7 \\
\hline DNK & 19.1 & 5.1 & 2.8 & 4.0 & 13.4 & 44.3 & 40.6 \\
\hline EST & 30.4 & 4.8 & 2.1 & 2.3 & 15.3 & 55.0 & 49.3 \\
\hline FIN & 14.1 & 3.7 & 2.5 & 2.9 & 10.7 & 33.9 & 36.2 \\
\hline FRA & 13.1 & 3.7 & 1.9 & 2.0 & 8.2 & 28.9 & 27.0 \\
\hline DEU & 15.8 & 5.8 & 3.2 & 2.6 & 9.6 & 37.1 & 31.9 \\
\hline GRC & 12.7 & 3.7 & 0.8 & 1.5 & 10.4 & 29.0 & 20.9 \\
\hline HUN & 32.5 & 6.0 & 2.4 & 2.4 & 12.2 & 55.5 & 45.1 \\
\hline ISL & 19.1 & 8.4 & 1.9 & 2.5 & 14.7 & 46.7 & 30.0 \\
\hline IRL & 29.3 & 11.9 & 2.7 & 5.2 & 15.2 & 64.4 & 49.0 \\
\hline ISR & 7.6 & 11.5 & 2.0 & 3.3 & 8.2 & 32.6 & 36.8 \\
\hline ITA & 12.5 & 4.7 & 1.8 & 1.9 & 9.4 & 30.2 & 26.8 \\
\hline JPN & 2.2 & 4.5 & 3.6 & 3.4 & 4.1 & 17.7 & 14.4 \\
\hline KOR & 3.5 & 6.8 & 7.7 & 5.1 & 8.8 & 31.9 & 26.8 \\
\hline LVA & 22.6 & 2.8 & 1.7 & 1.5 & 14.3 & 42.9 & 34.2 \\
\hline LTU & 23.8 & 3.3 & 1.2 & 1.4 & 13.5 & 43.3 & 34.6 \\
\hline LUX & 46.5 & 5.8 & 2.0 & 3.2 & 15.5 & 73.0 & 67.2 \\
\hline MEX & 1.3 & 18.4 & 0.9 & 0.8 & 3.4 & 24.9 & 19.9 \\
\hline NLD & 21.2 & 5.2 & 1.8 & 3.3 & 11.4 & 42.9 & 37.6 \\
\hline NZL & 3.2 & 4.6 & 5.1 & 4.7 & 10.2 & 27.7 & 28.4 \\
\hline NOR & 13.4 & 3.6 & 2.0 & 3.0 & 8.3 & 30.2 & 31.4 \\
\hline POL & 24.7 & 3.3 & 1.4 & 1.2 & 9.8 & 40.5 & 33.7 \\
\hline PRT & 21.3 & 4.6 & 1.6 & 1.3 & 10.9 & 39.7 & 27.7 \\
\hline SVK & 34.4 & 4.2 & 2.7 & 1.5 & 10.8 & 53.7 & 49.3 \\
\hline SVN & 31.7 & 3.6 & 1.6 & 1.4 & 13.7 & 51.9 & 46.8 \\
\hline ESP & 16.3 & 3.6 & 1.1 & 1.3 & 8.8 & 31.2 & 22.8 \\
\hline SWE & 16.3 & 4.5 & 2.4 & 2.4 & 11.8 & 37.4 & 41.5 \\
\hline $\mathrm{CHE}$ & 20.2 & 8.0 & 3.0 & 4.3 & 11.6 & 47.2 & 43.1 \\
\hline TUR & 10.9 & 2.4 & 0.8 & 0.8 & 9.7 & 24.7 & 24.1 \\
\hline GBR & 10.2 & 5.5 & 1.5 & 2.4 & 7.8 & 27.4 & 24.4 \\
\hline USA & 2.8 & 2.4 & 1.6 & 2.0 & 3.8 & 12.6 & 10.0 \\
\hline
\end{tabular}

Continue ... 
Table B.29. continued

\begin{tabular}{lrrrrrrr}
\hline & \multicolumn{7}{c}{2015} \\
Economy & EU28 & $\begin{array}{c}\text { North } \\
\text { America }\end{array}$ & China & $\begin{array}{c}\text { Other } \\
\text { E \& SE Asia }\end{array}$ & $\begin{array}{c}\text { Rest of } \\
\text { the world }\end{array}$ & Total & 2005 \\
\cline { 2 - 6 } ARG & 1.8 & 1.4 & 0.8 & 1.1 & 5.3 & 10.5 & 20.4 \\
BRA & 2.4 & 3.0 & 2.0 & 1.3 & 5.2 & 13.9 & 16.8 \\
BGR & 26.2 & 3.2 & 1.8 & 1.6 & 15.5 & 48.2 & 37.5 \\
CHN & 3.1 & 5.6 & 0.0 & 3.7 & 5.9 & 18.3 & 28.3 \\
COL & 1.5 & 4.5 & 0.9 & 0.5 & 4.6 & 12.0 & 14.2 \\
CRI & 5.5 & 12.5 & 2.1 & 2.3 & 9.5 & 31.9 & 38.8 \\
HRV & 23.5 & 2.9 & 1.2 & 1.1 & 11.6 & 40.4 & 35.2 \\
CYP & 16.8 & 2.3 & 2.0 & 3.3 & 22.1 & 46.6 & 42.8 \\
IND & 3.7 & 6.0 & 1.7 & 2.3 & 6.4 & 20.1 & 25.3 \\
IDN & 2.5 & 4.3 & 2.8 & 5.2 & 6.6 & 21.5 & 29.8 \\
MLT & 34.0 & 4.3 & 4.2 & 4.8 & 14.8 & 62.0 & 57.5 \\
ROU & 20.6 & 2.9 & 1.6 & 1.2 & 9.0 & 35.4 & 34.7 \\
RUS & 8.7 & 2.6 & 2.8 & 2.1 & 8.2 & 24.4 & 26.1 \\
SAU & 1.7 & 1.4 & 2.0 & 1.8 & 6.1 & 13.0 & 21.6 \\
ZAF & 5.3 & 4.0 & 4.6 & 2.5 & 11.9 & 28.3 & 27.2 \\
\hline
\end{tabular}

Note by Turkey: The information in this document with reference to "Cyprus" relates to the southern part of the Island. There is no single authority representing both Turkish and Greek Cypriot people on the Island. Turkey recognises the Turkish Republic of Northern Cyprus (TRNC). Until a lasting and equitable solution is found within the context of the United Nations, Turkey shall preserve its position concerning the "Cyprus issue".

Note by all the European Union Member States of the OECD and the European Union: The Republic of Cyprus is recognised by all members of the United Nations with the exception of Turkey. The information in this document relates to the area under the effective control of the Government of the Republic of Cyprus.

Source: OECD, Trade in Employment database, http://oe.cd/io-emp, 2019 
Table B.30. Labour compensation of employees in business sector embodied in foreign demand, by region of demand, 2015, as a percentage of total business sector labour compensation of employees (Figure 6.2)

\begin{tabular}{|c|c|c|c|c|c|c|c|}
\hline \multirow{2}{*}{ Economy } & \multicolumn{6}{|c|}{2015} & \multirow[b]{2}{*}{2005} \\
\hline & EU28 & $\begin{array}{c}\text { North } \\
\text { America }\end{array}$ & China & $\begin{array}{l}\text { Other E \& } \\
\text { SE Asia }\end{array}$ & $\begin{array}{c}\text { Rest of } \\
\text { the world }\end{array}$ & Total & \\
\hline OECD & 40.0 & 0.0 & 0.0 & 0.0 & 0.0 & 40.0 & 35.1 \\
\hline EU28 & 0.0 & 5.3 & 2.3 & 2.4 & 10.1 & 20.2 & 14.6 \\
\hline AUS & 1.8 & 2.7 & 5.9 & 5.8 & 4.8 & 21.1 & 18.9 \\
\hline AUT & 24.3 & 5.1 & 2.4 & 2.1 & 11.2 & 45.1 & 41.6 \\
\hline BEL & 29.5 & 6.3 & 2.1 & 2.6 & 12.0 & 52.5 & 49.5 \\
\hline CAN & 2.7 & 17.4 & 2.1 & 1.7 & 3.7 & 27.6 & 32.5 \\
\hline $\mathrm{CHL}$ & 3.2 & 5.2 & 5.4 & 3.6 & 8.0 & 25.5 & 31.7 \\
\hline CZE & 33.5 & 4.7 & 2.3 & 1.6 & 11.9 & 54.1 & 46.3 \\
\hline DNK & 19.0 & 5.3 & 2.8 & 4.0 & 13.5 & 44.6 & 40.8 \\
\hline EST & 30.6 & 5.0 & 2.2 & 2.4 & 15.6 & 55.6 & 47.9 \\
\hline FIN & 14.8 & 4.0 & 2.6 & 3.0 & 11.2 & 35.5 & 38.2 \\
\hline FRA & 13.6 & 3.9 & 2.0 & 2.1 & 8.6 & 30.1 & 28.0 \\
\hline DEU & 17.0 & 6.5 & 3.7 & 2.8 & 10.4 & 40.4 & 34.4 \\
\hline GRC & 13.4 & 4.0 & 0.9 & 1.7 & 11.4 & 31.4 & 21.5 \\
\hline HUN & 33.8 & 6.5 & 2.6 & 2.5 & 12.9 & 58.3 & 44.0 \\
\hline ISL & 19.8 & 8.7 & 1.9 & 2.7 & 15.8 & 48.8 & 28.8 \\
\hline IRL & 31.3 & 12.9 & 2.8 & 5.7 & 16.7 & 69.3 & 51.3 \\
\hline ISR & 8.3 & 12.3 & 2.3 & 3.8 & 8.7 & 35.4 & 39.2 \\
\hline ITA & 13.3 & 5.1 & 2.0 & 2.0 & 10.4 & 32.8 & 28.4 \\
\hline JPN & 2.4 & 5.0 & 3.9 & 3.6 & 4.5 & 19.4 & 15.8 \\
\hline KOR & 4.2 & 8.1 & 8.7 & 5.4 & 10.3 & 36.7 & 30.2 \\
\hline LVA & 22.3 & 2.8 & 1.6 & 1.6 & 14.6 & 42.9 & 34.2 \\
\hline LTU & 23.9 & 3.4 & 1.2 & 1.5 & 13.5 & 43.5 & 35.1 \\
\hline LUX & 48.2 & 6.1 & 2.2 & 3.8 & 17.4 & 77.6 & 72.9 \\
\hline MEX & 1.4 & 19.5 & 1.1 & 0.9 & 3.8 & 26.7 & 22.5 \\
\hline NLD & 21.7 & 5.2 & 1.9 & 3.4 & 11.6 & 44.0 & 38.2 \\
\hline NZL & 3.0 & 4.5 & 5.1 & 4.7 & 10.2 & 27.6 & 28.3 \\
\hline NOR & 15.4 & 3.9 & 2.0 & 3.1 & 8.4 & 32.7 & 33.1 \\
\hline POL & 24.7 & 3.4 & 1.4 & 1.2 & 10.0 & 40.9 & 32.8 \\
\hline PRT & 21.0 & 4.6 & 1.6 & 1.3 & 11.1 & 39.6 & 27.5 \\
\hline SVK & 35.2 & 4.5 & 2.9 & 1.5 & 11.3 & 55.6 & 49.6 \\
\hline SVN & 32.4 & 3.7 & 1.6 & 1.5 & 14.4 & 53.6 & 47.0 \\
\hline ESP & 16.7 & 3.8 & 1.2 & 1.3 & 9.3 & 32.4 & 23.6 \\
\hline SWE & 16.8 & 4.6 & 2.5 & 2.5 & 12.0 & 38.5 & 42.4 \\
\hline $\mathrm{CHE}$ & 21.5 & 9.0 & 3.2 & 4.7 & 12.7 & 51.1 & 47.5 \\
\hline TUR & 10.9 & 2.5 & 0.9 & 0.8 & 9.7 & 24.7 & 22.3 \\
\hline GBR & 10.9 & 6.1 & 1.7 & 2.6 & 8.4 & 29.7 & 26.7 \\
\hline USA & 3.1 & 2.5 & 1.6 & 2.2 & 4.1 & 13.5 & 10.8 \\
\hline
\end{tabular}

Continue ... 
Table B.30. continued

\begin{tabular}{|c|c|c|c|c|c|c|c|}
\hline \multirow{2}{*}{ Economy } & \multicolumn{6}{|c|}{2015} & \multirow[b]{2}{*}{2005} \\
\hline & EU28 & $\begin{array}{c}\text { North } \\
\text { America }\end{array}$ & China & $\begin{array}{l}\text { Other E \& } \\
\text { SE Asia }\end{array}$ & $\begin{array}{l}\text { Rest of } \\
\text { the world }\end{array}$ & Total & \\
\hline ARG & 2.0 & 1.9 & 0.9 & 1.2 & 6.3 & 12.3 & 22.7 \\
\hline BRA & 2.6 & 3.6 & 2.4 & 1.5 & 6.0 & 16.1 & 18.9 \\
\hline BRN & 1.4 & 2.1 & 2.3 & 14.4 & 7.0 & 27.2 & 41.2 \\
\hline BGR & 26.2 & 3.3 & 1.9 & 1.6 & 15.5 & 48.5 & 38.0 \\
\hline KHM & 6.1 & 8.0 & 3.9 & 8.8 & 7.4 & 34.1 & 36.9 \\
\hline $\mathrm{CHN}$ & 3.4 & 6.1 & 0.0 & 4.0 & 6.5 & 20.1 & 28.4 \\
\hline COL & 2.1 & 5.7 & 1.4 & 0.7 & 5.0 & 14.8 & 16.2 \\
\hline CRI & 6.4 & 12.7 & 2.1 & 2.7 & 9.6 & 33.6 & 37.9 \\
\hline HRV & 22.6 & 2.9 & 1.2 & 1.1 & 11.3 & 39.1 & 33.3 \\
\hline CYP & 17.7 & 2.5 & 2.1 & 3.7 & 23.6 & 49.6 & 44.6 \\
\hline IND & 3.1 & 5.3 & 1.2 & 2.2 & 5.7 & 17.6 & 16.3 \\
\hline IDN & 2.0 & 3.0 & 2.7 & 5.1 & 6.0 & 18.8 & 28.3 \\
\hline HKG & 6.6 & 5.3 & 13.1 & 7.5 & 9.4 & 41.8 & 43.8 \\
\hline KAZ & 10.6 & 2.4 & 4.4 & 1.4 & 8.8 & 27.6 & 40.8 \\
\hline MYS & 5.4 & 8.4 & 9.6 & 12.1 & 11.4 & 47.0 & 57.9 \\
\hline MLT & 37.5 & 4.4 & 4.3 & 4.7 & 16.3 & 67.1 & 62.2 \\
\hline MAR & 15.5 & 3.6 & 1.3 & 2.0 & 11.6 & 33.9 & 37.3 \\
\hline PER & 2.5 & 5.3 & 4.2 & 1.7 & 5.8 & 19.5 & 25.8 \\
\hline PHL & 4.0 & 7.9 & 4.9 & 9.0 & 5.4 & 31.1 & 29.0 \\
\hline ROU & 21.7 & 3.2 & 1.6 & 1.3 & 9.7 & 37.4 & 33.2 \\
\hline RUS & 9.6 & 2.8 & 2.9 & 2.3 & 8.5 & 26.1 & 28.5 \\
\hline SAU & 2.5 & 2.2 & 2.8 & 2.7 & 7.9 & 18.1 & 32.7 \\
\hline SGP & 12.4 & 9.5 & 9.2 & 19.1 & 17.8 & 68.0 & 69.8 \\
\hline ZAF & 6.0 & 4.4 & 6.0 & 3.0 & 14.4 & 33.9 & 28.8 \\
\hline TWN & 5.5 & 10.6 & 15.8 & 10.2 & 9.4 & 51.4 & 48.1 \\
\hline THA & 6.1 & 8.8 & 8.2 & 12.7 & 15.5 & 51.4 & 47.5 \\
\hline TUN & 24.8 & 3.0 & 1.2 & 1.3 & 10.8 & 41.0 & 46.6 \\
\hline VNM & 6.6 & 13.4 & 6.8 & 12.5 & 11.6 & 50.8 & 42.1 \\
\hline
\end{tabular}

Note by Turkey: The information in this document with reference to "Cyprus" relates to the southern part of the Island. There is no single authority representing both Turkish and Greek Cypriot people on the Island. Turkey recognises the Turkish Republic of Northern Cyprus (TRNC). Until a lasting and equitable solution is found within the context of the United Nations, Turkey shall preserve its position concerning the "Cyprus issue".

Note by all the European Union Member States of the OECD and the European Union: The Republic of Cyprus is recognised by all members of the United Nations with the exception of Turkey. The information in this document relates to the area under the effective control of the Government of the Republic of Cyprus.

Source: OECD, Trade in Employment database, http://oe.cd/io-emp, 2019. 
Table B.31. High-skilled employment in manufacturing meeting domestic and foreign demand, 2015, as a percentage of total manufacturing employment (Figure 6.3)

\begin{tabular}{|c|c|c|}
\hline Country & $\begin{array}{l}\text { Foreign final } \\
\text { demand }\end{array}$ & $\begin{array}{l}\text { Domestic } \\
\text { final demand }\end{array}$ \\
\hline AUS & 9.7 & 21.3 \\
\hline AUT & 21.9 & 10.9 \\
\hline BEL & 22.2 & 11.9 \\
\hline CAN & 15.8 & 20.0 \\
\hline CZE & 17.9 & 6.6 \\
\hline DNK & 26.3 & 13.5 \\
\hline EST & 18.6 & 6.3 \\
\hline FIN & 23.2 & 17.1 \\
\hline FRA & 21.4 & 20.0 \\
\hline DEU & 19.2 & 13.5 \\
\hline GRC & 8.0 & 9.3 \\
\hline HUN & 15.6 & 4.8 \\
\hline ISL & 14.5 & 10.6 \\
\hline IRL & 26.8 & 6.9 \\
\hline ITA & 13.9 & 13.4 \\
\hline JPN & 5.0 & 10.1 \\
\hline LVA & 15.1 & 10.7 \\
\hline LTU & 14.9 & 8.8 \\
\hline LUX & 30.1 & 7.9 \\
\hline NLD & 21.6 & 13.9 \\
\hline NOR & 16.6 & 23.3 \\
\hline POL & 15.3 & 10.4 \\
\hline PRT & 13.7 & 8.0 \\
\hline SVK & 14.2 & 3.8 \\
\hline SVN & 21.6 & 6.8 \\
\hline ESP & 12.8 & 13.1 \\
\hline SWE & 25.5 & 15.6 \\
\hline $\mathrm{CHE}$ & 31.2 & 12.0 \\
\hline TUR & 5.2 & 9.3 \\
\hline GBR & 17.9 & 21.4 \\
\hline USA & 8.5 & 30.3 \\
\hline ARG & 1.5 & 11.1 \\
\hline ZAF & 7.7 & 9.1 \\
\hline
\end{tabular}

Source: OECD, Trade in Employment database, http://oe.cd/io-emp, 2019. 
Table B.32. $\mathrm{CO}_{2}$ emissions from fuel combustion (OECD and non-OECD countries), consumption-based and production-based (Gt CO2) (Figure 6.4)

\begin{tabular}{ccccccc}
\hline \multirow{2}{*}{ Year } & \multicolumn{5}{c}{ OECD } & \multicolumn{3}{c}{ non-OECD } \\
\cline { 2 - 7 } & Consumption & Production & $\begin{array}{c}\text { Balance } \\
\text { Net Importers }\end{array}$ & Consumption & Production & $\begin{array}{c}\text { Balance } \\
\text { Net exporters }\end{array}$ \\
\hline 2005 & 15.6 & 13.4 & 2.1 & 11.5 & 13.6 & -2.1 \\
2006 & 15.7 & 13.4 & 2.3 & 12.3 & 14.5 & -2.3 \\
2007 & 15.8 & 13.6 & 2.2 & 13.2 & 15.4 & -2.2 \\
2008 & 15.3 & 13.2 & 2.1 & 13.9 & 16.0 & -2.1 \\
2009 & 14.0 & 12.4 & 1.6 & 14.8 & 16.4 & -1.6 \\
2010 & 14.7 & 12.9 & 1.8 & 15.8 & 17.6 & -1.8 \\
2011 & 14.5 & 12.7 & 1.9 & 16.8 & 18.7 & -1.9 \\
2012 & 14.2 & 12.5 & 1.7 & 17.5 & 19.2 & -1.7 \\
2013 & 14.2 & 12.5 & 1.6 & 18.1 & 19.8 & -1.6 \\
2014 & 13.9 & 12.3 & 1.7 & 18.4 & 20.0 & -1.7 \\
2015 & 13.8 & 12.2 & 1.6 & 18.5 & 20.1 & -1.6 \\
\hline
\end{tabular}

Source: OECD's Carbon dioxide $\left(\mathrm{CO}_{2}\right)$ emissions embodied in international trade (TECO2) database (http://oe.cd/io-co2), 2019. 
Table B.33. Per capita $\mathrm{CO}_{2}$ emissions from fuel combustion, consumption-based and production-based (tonnes CO2) (Figure 6.5)

\begin{tabular}{|c|c|c|c|c|}
\hline \multirow{2}{*}{ Country } & \multicolumn{2}{|c|}{2005} & \multicolumn{2}{|c|}{2015} \\
\hline & Consumption & Production & Consumption & Production \\
\hline OECD & 13.0 & 11.2 & 10.8 & 9.5 \\
\hline AUS & 20.7 & 18.9 & 17.9 & 16.5 \\
\hline AUT & 11.5 & 9.1 & 9.6 & 7.4 \\
\hline BEL & 12.5 & 11.3 & 10.4 & 9.0 \\
\hline CAN & 16.7 & 17.2 & 15.2 & 15.5 \\
\hline $\mathrm{CHL}$ & 3.8 & 3.8 & 5.0 & 4.9 \\
\hline CZE & 10.2 & 11.5 & 8.7 & 9.4 \\
\hline DNK & 14.5 & 15.8 & 10.4 & 11.4 \\
\hline EST & 11.2 & 12.2 & 10.1 & 11.9 \\
\hline FIN & 12.4 & 11.1 & 9.5 & 8.3 \\
\hline FRA & 8.8 & 6.3 & 6.9 & 4.8 \\
\hline DEU & 11.5 & 10.0 & 10.4 & 9.4 \\
\hline GRC & 10.8 & 9.9 & 6.5 & 6.9 \\
\hline HUN & 6.8 & 6.2 & 4.9 & 5.2 \\
\hline ISL & 15.4 & 14.0 & 8.7 & 12.5 \\
\hline IRL & 15.0 & 14.5 & 9.9 & 11.2 \\
\hline ISR & 12.7 & 10.2 & 10.9 & 8.8 \\
\hline ITA & 9.9 & 7.9 & 7.1 & 5.8 \\
\hline JPN & 11.7 & 9.5 & 10.6 & 9.4 \\
\hline KOR & 11.2 & 10.5 & 11.6 & 12.5 \\
\hline LVA & 4.9 & 3.5 & 4.6 & 3.6 \\
\hline LTU & 5.0 & 3.8 & 4.8 & 3.5 \\
\hline LUX & 25.6 & 27.1 & 16.1 & 16.9 \\
\hline MEX & 4.1 & 3.9 & 3.9 & 3.6 \\
\hline NLD & 12.3 & 12.0 & 10.6 & 10.7 \\
\hline NZL & 11.0 & 8.7 & 9.3 & 7.4 \\
\hline NOR & 12.2 & 10.9 & 11.5 & 10.0 \\
\hline POL & 7.2 & 7.8 & 7.2 & 7.4 \\
\hline PRT & 7.4 & 6.1 & 5.0 & 4.8 \\
\hline SVK & 6.1 & 6.8 & 5.6 & 5.4 \\
\hline SVN & 8.9 & 7.8 & 6.7 & 6.2 \\
\hline ESP & 9.3 & 8.0 & 6.3 & 5.7 \\
\hline SWE & 9.1 & 6.4 & 7.2 & 4.5 \\
\hline $\mathrm{CHE}$ & 12.5 & 7.2 & 11.3 & 5.4 \\
\hline TUR & 4.1 & 3.3 & 4.8 & 4.3 \\
\hline GBR & 12.2 & 9.4 & 8.8 & 6.6 \\
\hline USA & 23.0 & 19.8 & 18.1 & 15.7 \\
\hline
\end{tabular}

Continue ... 
Table B.33. continued

\begin{tabular}{|c|c|c|c|c|}
\hline \multirow{2}{*}{ Country } & \multicolumn{2}{|c|}{2005} & \multicolumn{2}{|c|}{2015} \\
\hline & Consumption & Production & Consumption & Production \\
\hline ARG & 3.6 & 3.9 & 5.0 & 4.5 \\
\hline BRA & 1.7 & 1.7 & 2.3 & 2.2 \\
\hline BRN & 11.2 & 14.1 & 15.3 & 16.1 \\
\hline BGR & 5.1 & 6.1 & 4.8 & 6.1 \\
\hline KHM & 0.5 & 0.2 & 0.8 & 0.6 \\
\hline $\mathrm{CHN}$ & 3.2 & 4.1 & 5.7 & 6.6 \\
\hline $\mathrm{COL}$ & 1.5 & 1.3 & 2.0 & 1.7 \\
\hline CRI & 2.1 & 1.5 & 2.8 & 1.7 \\
\hline HRV & 5.6 & 4.4 & 4.0 & 3.6 \\
\hline CYP & 10.6 & 10.1 & 6.8 & 6.3 \\
\hline IND & 0.9 & 0.9 & 1.5 & 1.6 \\
\hline IDN & 1.3 & 1.5 & 1.9 & 1.9 \\
\hline HKG & 10.5 & 8.7 & 14.4 & 9.7 \\
\hline $\mathrm{KAZ}$ & 6.5 & 10.2 & 10.2 & 12.8 \\
\hline MYS & 4.8 & 6.6 & 6.8 & 7.8 \\
\hline MLT & 7.3 & 8.8 & 6.1 & 7.3 \\
\hline MAR & 1.5 & 1.4 & 1.9 & 1.7 \\
\hline PER & 1.1 & 1.0 & 2.0 & 1.6 \\
\hline PHL & 0.9 & 0.9 & 1.3 & 1.1 \\
\hline ROU & 4.1 & 4.3 & 3.6 & 3.6 \\
\hline RUS & 7.7 & 10.4 & 8.1 & 10.3 \\
\hline SAU & 11.7 & 12.7 & 18.9 & 17.2 \\
\hline SGP & 11.3 & 16.4 & 12.7 & 22.1 \\
\hline ZAF & 6.2 & 7.7 & 5.7 & 7.5 \\
\hline TWN & 10.4 & 11.9 & 9.0 & 11.4 \\
\hline THA & 3.0 & 3.3 & 3.4 & 3.9 \\
\hline TUN & 2.1 & 2.1 & 2.6 & 2.4 \\
\hline VNM & 0.9 & 1.0 & 1.6 & 1.9 \\
\hline ROW & 1.4 & 1.5 & 1.7 & 1.6 \\
\hline
\end{tabular}

Note by Turkey: The information in this document with reference to "Cyprus" relates to the southern part of the Island. There is no single authority representing both Turkish and Greek Cypriot people on the Island. Turkey recognises the Turkish Republic of Northern Cyprus (TRNC). Until a lasting and equitable solution is found within the context of the United Nations, Turkey shall preserve its position concerning the "Cyprus issue".

Note by all the European Union Member States of the OECD and the European Union: The Republic of Cyprus is recognised by all members of the United Nations with the exception of Turkey. The information in this document relates to the area under the effective control of the Government of the Republic of Cyprus.

Source: OECD's Carbon dioxide $\left(\mathrm{CO}_{2}\right)$ emissions embodied in international trade (TECO2) database (http://oe.cd/io-co2), 2019. 
Table B.34. Share of $\mathrm{CO} 2$ emitted abroad in total $\mathrm{CO} 2$ embodied in domestic final demand (Figure 6.6)

\begin{tabular}{lrrrrrr}
\hline \multirow{2}{*}{ Country } & \multicolumn{7}{c}{2005} & & & 2015 & \\
\cline { 2 - 7 } & OECD & Non-OECD & Total foreign & OECD & Non-OECD & Total foreign \\
\hline AUS & 6.7 & 18.7 & 25.4 & 7.2 & 22.7 & 29.9 \\
AUT & 23.8 & 23.1 & 46.9 & 25.4 & 27.1 & 52.6 \\
BEL & 22.0 & 21.6 & 43.5 & 22.8 & 23.6 & 46.4 \\
CAN & 15.7 & 15.7 & 31.3 & 13.8 & 16.0 & 29.8 \\
CHL & 10.0 & 29.4 & 39.4 & 9.5 & 26.5 & 36.0 \\
CZE & 12.7 & 13.7 & 26.3 & 14.6 & 17.2 & 31.8 \\
DNK & 22.7 & 20.9 & 43.6 & 26.7 & 25.3 & 52.0 \\
EST & 9.3 & 18.4 & 27.7 & 10.1 & 18.5 & 28.6 \\
FIN & 16.5 & 27.9 & 44.3 & 17.6 & 25.1 & 42.6 \\
FRA & 20.0 & 23.9 & 43.9 & 19.4 & 26.1 & 45.6 \\
DEU & 15.0 & 16.7 & 31.7 & 14.0 & 18.7 & 32.8 \\
GRC & 11.2 & 19.3 & 30.5 & 9.5 & 17.8 & 27.4 \\
HUN & 14.3 & 18.6 & 32.9 & 16.8 & 18.3 & 35.1 \\
ISL & 39.3 & 25.7 & 65.0 & 33.6 & 26.2 & 59.8 \\
IRL & 23.2 & 14.9 & 38.1 & 25.3 & 18.3 & 43.6 \\
ISR & 11.2 & 22.7 & 33.8 & 10.9 & 23.3 & 34.3 \\
ITA & 13.5 & 21.5 & 35.0 & 12.5 & 22.4 & 34.9 \\
JPN & 6.9 & 23.0 & 29.8 & 5.8 & 20.2 & 26.0 \\
KOR & 8.2 & 24.7 & 32.9 & 7.1 & 22.6 & 29.7 \\
LVA & 20.4 & 30.4 & 50.8 & 21.9 & 27.0 & 48.9 \\
LTU & 15.5 & 32.2 & 47.8 & 20.1 & 34.6 & 54.7 \\
LUX & 23.3 & 10.4 & 33.7 & 24.2 & 11.8 & 36.0 \\
MEX & 12.5 & 10.2 & 22.7 & 12.1 & 14.8 & 26.9 \\
NLD & 17.0 & 19.3 & 36.2 & 15.7 & 19.4 & 35.1 \\
NZL & 17.0 & 25.8 & 42.8 & 13.7 & 30.6 & 44.3 \\
NOR & 29.8 & 27.9 & 57.6 & 27.8 & 28.9 & 56.6 \\
POL & 7.9 & 10.8 & 18.7 & 9.2 & 13.6 & 22.8 \\
PRT & 18.2 & 15.2 & 33.4 & 17.2 & 16.5 & 33.8 \\
SVK & 19.9 & 23.6 & 43.5 & 24.6 & 29.7 & 54.3 \\
SVN & 19.1 & 20.8 & 39.9 & 17.4 & 21.6 & 38.9 \\
ESP & 14.2 & 19.9 & 34.1 & 13.0 & 20.1 & 33.1 \\
SWE & 31.8 & 23.6 & 55.4 & 30.8 & 27.9 & 58.7 \\
CHE & 29.9 & 27.3 & 57.2 & 30.2 & 34.5 & 64.7 \\
TUR & 8.9 & 25.6 & 34.5 & 7.6 & 22.5 & 30.1 \\
GBR & 16.4 & 20.6 & 37.0 & 16.8 & 23.3 & 40.1 \\
USA & 6.1 & 13.8 & 19.9 & 6.5 & 14.1 & 20.6 \\
\hline & & & & & & \\
\hline
\end{tabular}

Continue ... 
Table B.34. continued

\begin{tabular}{lrrrrrr}
\hline \multirow{2}{*}{ Country } & \multicolumn{7}{c}{2005} & & & 2015 & \\
\cline { 2 - 7 } & OECD & Non-OECD & Total foreign & OECD & Non-OECD & Total foreign \\
\hline ARG & 4.7 & 12.0 & 16.7 & 4.8 & 13.5 & 18.3 \\
BRA & 6.7 & 13.7 & 20.4 & 6.8 & 14.9 & 21.7 \\
BRN & 10.1 & 19.1 & 29.2 & 8.7 & 20.5 & 29.2 \\
BGR & 8.0 & 13.8 & 21.8 & 10.1 & 16.3 & 26.5 \\
KHM & 7.0 & 52.9 & 59.9 & 5.5 & 39.3 & 44.8 \\
CHN & 2.6 & 4.0 & 6.6 & 3.3 & 4.6 & 7.9 \\
COL & 10.6 & 19.0 & 29.6 & 11.4 & 22.5 & 34.0 \\
CRI & 21.7 & 28.1 & 49.8 & 19.6 & 32.5 & 52.1 \\
HRV & 16.7 & 21.8 & 38.5 & 16.1 & 16.3 & 32.4 \\
CYP & 15.7 & 22.0 & 37.6 & 17.2 & 25.4 & 42.6 \\
IND & 3.5 & 10.2 & 13.8 & 3.0 & 10.0 & 13.1 \\
IDN & 5.0 & 15.4 & 20.4 & 4.4 & 16.2 & 20.6 \\
HKG & 17.8 & 43.3 & 61.2 & 19.1 & 45.6 & 64.7 \\
KAZ & 2.7 & 15.1 & 17.9 & 2.1 & 13.0 & 15.2 \\
MYS & 9.1 & 22.2 & 31.3 & 6.5 & 21.8 & 28.3 \\
MLT & 21.0 & 18.9 & 39.9 & 22.0 & 22.3 & 44.3 \\
MAR & 9.7 & 16.4 & 26.2 & 11.0 & 15.5 & 26.5 \\
PER & 11.0 & 21.3 & 32.4 & 11.4 & 25.2 & 36.6 \\
PHL & 7.8 & 16.9 & 24.7 & 7.9 & 24.8 & 32.7 \\
ROU & 8.5 & 14.6 & 23.1 & 12.1 & 16.1 & 28.2 \\
RUS & 2.9 & 5.1 & 8.0 & 2.6 & 6.3 & 9.0 \\
SAU & 5.7 & 11.6 & 17.3 & 6.6 & 14.6 & 21.1 \\
SGP & 18.6 & 42.0 & 60.6 & 18.4 & 42.4 & 60.9 \\
ZAF & 4.2 & 8.6 & 12.8 & 3.1 & 10.6 & 13.7 \\
TWN & 12.4 & 24.9 & 37.3 & 10.2 & 25.1 & 35.3 \\
THA & 9.4 & 24.9 & 34.3 & 7.9 & 26.1 & 34.1 \\
TUN & 11.1 & 16.2 & 27.3 & 8.4 & 15.9 & 24.4 \\
VNM & 6.9 & 30.6 & 37.5 & 8.3 & 30.2 & 38.4 \\
ROW & 7.3 & 14.2 & 21.5 & 7.7 & 16.9 & 24.6 \\
\hline & & & & & & \\
\hline
\end{tabular}

Note by Turkey: The information in this document with reference to "Cyprus" relates to the southern part of the Island. There is no single authority representing both Turkish and Greek Cypriot people on the Island. Turkey recognises the Turkish Republic of Northern Cyprus (TRNC). Until a lasting and equitable solution is found within the context of the United Nations, Turkey shall preserve its position concerning the "Cyprus issue". Note by all the European Union Member States of the OECD and the European Union: The Republic of Cyprus is recognised by all members of the United Nations with the exception of Turkey. The information in this document relates to the area under the effective control of the Government of the Republic of Cyprus.

Source: OECD's Carbon dioxide $\left(\mathrm{CO}_{2}\right)$ emissions embodied in international trade (TECO2) database (http:/oe.cd/io-co2), 2019. 
Table B.35. Regional demand for information industries products, 2005 and 2015, by country or region of value added origin, percentage shares of total (Box 4.1)

\begin{tabular}{|c|c|c|c|c|c|c|c|c|c|c|c|c|}
\hline \multicolumn{13}{|c|}{ Inter-regional value added in domestic final demand } \\
\hline \multirow{2}{*}{ Country or region } & \multicolumn{2}{|c|}{$\begin{array}{l}\text { United } \\
\text { States } \\
\end{array}$} & \multicolumn{2}{|c|}{ EU28 } & \multicolumn{2}{|c|}{ China } & \multicolumn{2}{|c|}{ Japan } & \multicolumn{2}{|c|}{$\begin{array}{c}\text { Other E\&SE } \\
\text { Asia }\end{array}$} & \multicolumn{2}{|c|}{$\begin{array}{l}\text { Rest of the } \\
\text { World }\end{array}$} \\
\hline & 2005 & 2015 & 2005 & 2015 & 2005 & 2015 & 2005 & 2015 & 2005 & 2015 & 2005 & 2015 \\
\hline United States & 81.8 & 84.9 & 5.1 & 4.9 & 5.5 & 4.6 & 2.8 & 3.3 & 7.5 & 5.4 & 9.2 & 7.4 \\
\hline EU28 & 3.9 & 2.5 & 82.0 & 78.6 & 4.8 & 3.7 & 2.1 & 3.3 & 6.0 & 5.4 & 9.5 & 8.5 \\
\hline China & 3.2 & 4.2 & 2.3 & 5.2 & 58.6 & 70.4 & 2.3 & 5.6 & 4.4 & 9.5 & 3.5 & 9.0 \\
\hline Japan & 2.2 & 0.7 & 1.8 & 1.0 & 7.6 & 2.9 & 86.9 & 79.2 & 7.4 & 3.7 & 2.3 & 1.2 \\
\hline Other E\&SE Asia & 4.1 & 2.3 & 3.5 & 3.3 & 18.5 & 13.6 & 3.5 & 4.5 & 68.2 & 68.4 & 5.0 & 4.9 \\
\hline Rest of the World & 4.8 & 5.4 & 5.4 & 7.0 & 5.0 & 4.7 & 2.4 & 4.1 & 6.5 & 7.6 & 70.5 & 69.0 \\
\hline \multicolumn{13}{|c|}{ Inter-regional foreign value added in domestic final demand } \\
\hline \multirow{2}{*}{ Country or region } & \multicolumn{2}{|c|}{$\begin{array}{l}\text { United } \\
\text { States }\end{array}$} & \multicolumn{2}{|c|}{ EU28 } & \multicolumn{2}{|c|}{ China } & \multicolumn{2}{|c|}{ Japan } & \multicolumn{2}{|c|}{$\begin{array}{c}\text { Other E\&SE } \\
\text { Asia }\end{array}$} & \multicolumn{2}{|c|}{$\begin{array}{l}\text { Rest of the } \\
\text { World }\end{array}$} \\
\hline & 2005 & 2015 & 2005 & 2015 & 2005 & 2015 & 2005 & 2015 & 2005 & 2015 & 2005 & 2015 \\
\hline United States & 0.0 & 0.0 & 28.4 & 22.9 & 13.2 & 15.5 & 21.7 & 15.7 & 23.7 & 17.2 & 31.3 & 23.8 \\
\hline EU28 & 21.4 & 16.5 & 0.0 & 0.0 & 11.6 & 12.6 & 16.1 & 16.1 & 18.8 & 17.1 & 32.2 & 27.4 \\
\hline China & 17.6 & 27.9 & 12.6 & 24.2 & 0.0 & 0.0 & 17.5 & 27.0 & 13.8 & 30.1 & 11.8 & 28.9 \\
\hline Japan & 12.2 & 4.7 & 10.0 & 4.7 & 18.4 & 9.9 & 0.0 & 0.0 & 23.2 & 11.6 & 7.8 & 3.9 \\
\hline Other E\&SE Asia & 22.5 & 15.5 & 19.2 & 15.6 & 44.7 & 46.1 & 26.7 & 21.5 & 0.0 & 0.0 & 16.9 & 16.0 \\
\hline Rest of the World & 26.3 & 35.4 & 29.8 & 32.6 & 12.1 & 15.8 & 18.1 & 19.7 & 20.5 & 24.1 & 0.0 & 0.0 \\
\hline
\end{tabular}

Source: Estimation based on OECD’s Inter-Country Input-Output Database, 2018

Table B.36. US imports of electronics, machinery and transport equipment from Mexico, by country or region origin of value added, 2005 to 2015, USD billions (Box 4.2)

\begin{tabular}{cccccccc}
\hline Year & Mexico & USA & Canada & EU28 & China & $\begin{array}{c}\text { Other } \\
\text { E\&SE Asia }\end{array}$ & $\begin{array}{c}\text { Rest of the } \\
\text { World }\end{array}$ \\
\hline 2005 & 36.5 & 17.4 & 1.1 & 5.6 & 3.9 & 10.1 & 4.1 \\
2006 & 42.8 & 19.2 & 1.3 & 5.9 & 5.4 & 11.6 & 5.1 \\
2007 & 45.0 & 18.8 & 1.4 & 6.3 & 6.4 & 11.7 & 5.1 \\
2008 & 43.8 & 17.4 & 1.4 & 6.5 & 7.7 & 11.1 & 5.5 \\
2009 & 36.6 & 13.5 & 1.0 & 4.7 & 7.7 & 9.6 & 3.8 \\
2010 & 49.5 & 18.1 & 1.4 & 6.1 & 10.3 & 12.3 & 6.0 \\
2011 & 54.9 & 19.2 & 1.6 & 6.8 & 10.9 & 11.3 & 6.8 \\
2012 & 59.4 & 21.7 & 1.7 & 7.9 & 12.8 & 12.1 & 7.4 \\
2013 & 62.5 & 23.4 & 1.7 & 8.7 & 14.7 & 12.5 & 7.4 \\
2014 & 72.8 & 25.3 & 1.9 & 9.0 & 15.9 & 12.9 & 7.5 \\
2015 & 78.5 & 27.9 & 1.7 & 9.5 & 18.7 & 14.0 & 7.3 \\
\hline
\end{tabular}

Source: OECD, Trade in Value Added database, http://oe.cd/tiva, 2018, Origin of value added in gross imports 
Table B.37. US imports of electronics, machinery and transport equipment from Mexico, by country or region and industry origin of value added, 2015, USD millions (Box 4.2)

\begin{tabular}{|c|c|c|c|c|c|c|c|}
\hline Industry & Mexico & USA & Canada & EU28 & China & $\begin{array}{c}\text { Other } \\
\text { E\&SE } \\
\text { Asia }\end{array}$ & $\begin{array}{l}\text { Rest of } \\
\text { the world }\end{array}$ \\
\hline $\begin{array}{l}\text { Agriculture and mining } \\
\text { (ISIC Rev.4 Divisions } 01 \text { to 09) }\end{array}$ & 2341 & 1106 & 344 & 126 & 1271 & 310 & 1990 \\
\hline $\begin{array}{l}\text { Food, textiles and wood products } \\
(10 \text { to } 18)\end{array}$ & 765 & 593 & 40 & 195 & 736 & 240 & 188 \\
\hline $\begin{array}{l}\text { Chemicals, metals and other } \\
\text { mineral products (19 to } 25)\end{array}$ & 6547 & 5756 & 397 & 1808 & 3438 & 2096 & 1284 \\
\hline $\begin{array}{l}\text { Electronics, machinery and } \\
\text { transport equipment ( } 26 \text { to } 30)\end{array}$ & 42097 & 7389 & 269 & 2888 & 6067 & 6379 & 1090 \\
\hline $\begin{array}{l}\text { Other manufactures, utilities and } \\
\text { construction ( } 31 \text { to } 43)\end{array}$ & 822 & 527 & 73 & 497 & 720 & 388 & 318 \\
\hline $\begin{array}{l}\text { Trade, transport, accommodation } \\
\text { and food services ( } 45 \text { to } 56 \text { ) }\end{array}$ & 17489 & 6959 & 345 & 2041 & 3720 & 2981 & 1485 \\
\hline $\begin{array}{l}\text { ICT, Finance and other services } \\
\text { (58 to } 98 \text { ) }\end{array}$ & 8404 & 5525 & 260 & 1988 & 2705 & 1587 & 974 \\
\hline TOTAL & 78463 & 27855 & 1727 & 9544 & 18658 & 13981 & 7329 \\
\hline
\end{tabular}

Source: OECD, Trade in Value Added database, http://oe.cd/tiva, 2018, Origin of value added in gross imports 